Vol. XXVI, pp. 215-315

Editor, EDMUNd OtIS Hovey 


\section{THE NEW YORK ACADEMY OF SCIENCES}

\section{(Lycedm of Natural History, 1817-1876)}

\section{OFFICERS, 1915}

President-George Frederick Kunz, 601 West 110th Street Vice-Presidents-Charles P. Berkex, Raymond C. Osburn, Charles Baskerville, Clark Wissler

Corresponding Secretary-Henry E. Crampton, American Museum Recording Secretary-Edmund Otis Hovey, American Museum Treasurer-Henry J. Cochinan, 389 Fifth Avenue Librarian-RaLPH W. Tower, American Museum Éditor-Epmund Otis Hover, American Museum

\section{SECTION OF GEOLOGY AND MINERALOGY}

Chairman-Charles 1'. Berkex, Columbia University Secretary-D. W. JoHnson, Columbia University .

\section{SECTION OF BIOLOGY}

Chairman-Raymond C. Osburn, 557' West 124th Street . Secretary-William K. Gregory, American Museum

$$
\text { SECTION OF ASTRONOMY, PHYSICS AND CHEMISTRY }
$$

Chairman-Charles Baskerville, College of the City of New York Secretary-ERnest E. SMith, 50 East 41st Street

$$
\text { SECTION OF ANTHROPOLOGY AND PSYCHOLOGY }
$$

Chairman-Clark Wissler, American Museum Secretary-Roвert H. Lowie, American Museum

The sessions of the Academy are held on Monday evenings at 8:15 o'clock from October to May, inclusive, at the American Museum of Natural History, $7 \%$ th Street and Central Park, West. 
[ANNALS N. I. ACAD. SCI., Vol. XXVI, pp. 215-315. 30 July, 1915]

\title{
REVIEW OF THE PLEISTOCENE OF EUROPE, ASIA AND NORTHERN AFRICA ${ }^{1}$
}

\author{
Br Henry Fatrfietd Osbora
}

(Presented by title before the Academy, 19 Aprit, 1915)

\section{CONTENTS}

Page

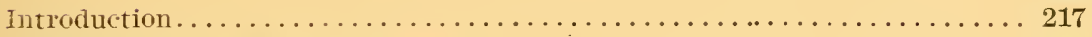

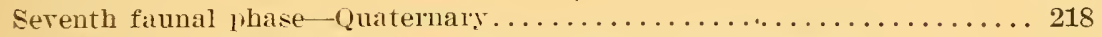

Ieans of establishing the time divisions of the Quaternary........ 218

Pliocene and Pleistocene life of Asia and North Africa............. 219

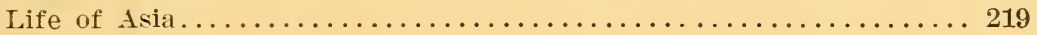

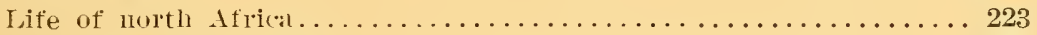

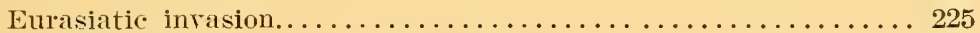

Sources of the Pleistocene African life................. 225

Asiatic and European affinities..................... 226

African-European distribution..................... 228

Africa in Palæolithic and Neolithic times................. 229

Fleistocene or Glacial epoch in Europe........................ 229

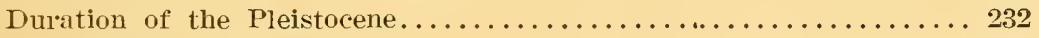

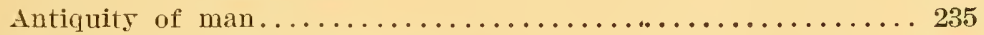

Geologic age of the culture stages..................... 236

Eleration and subsidence of land in Quaternary times.......... 237

Final subsidence............................... 239

Final elevation............................... 240

Alternations of climate and flora.......................... 240

Low glacial stage temperatures.................... 240

Moderate estimates of temperature................. 241

Trarm and temperate interglacial stages................ 241

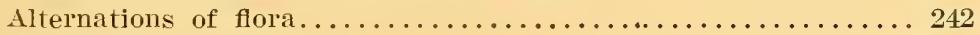

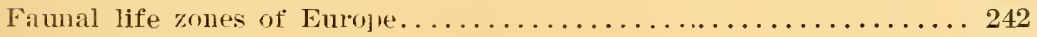

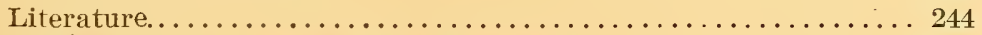

African-Asiatic mammals, warm fauna................ 244

Eurasiatic forest and meadow, temperate fauna........... 245

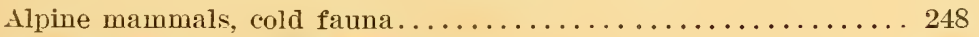

Steppe fauna of Russia and Siberia................ 248

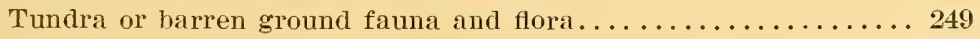

Migration theory of floras and faunas.................... 250

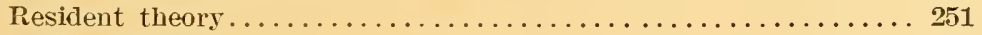

Latitude and altitude................................ 251

\footnotetext{
I Revision for German edition of the author's work, "The Age of Mammals;" German translator and editor, Tr. W. O. Dietrich, Kgl. Geologisch-palæontologisches Institut und Museum, Berlin.
}

Manuscript received by the Editor 25 January, 1915. 
Page

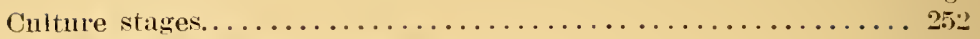

Repetition of loess depositions..................... 25:

First Glacial stage-Günz, Scanian, Nebraskan............... 252

First Interglacial stage-Norfolkian, Aftonian. Giinz-Mindel......... 25.5

Humid forest conditions........................... 255

Flora of the first Interglacial period...................... 250

Mammals of the first Interglacial stage .................. 256

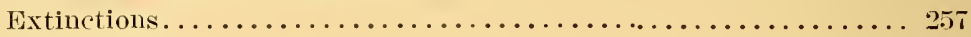

Survivals....................... 257

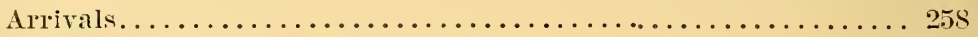

First Interglacial of France......................... 260

Southeru elephant (Elephas meridionalis)............... 261

Hippopotami................................ 263

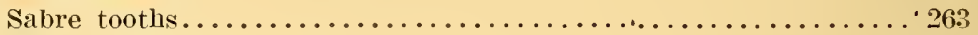

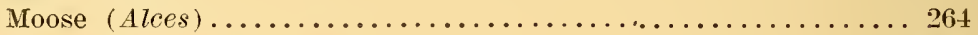

Problematic evidence of man.............................. 264

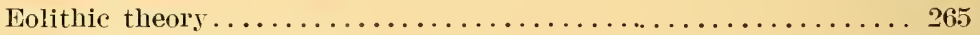

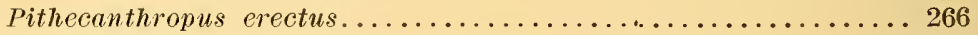

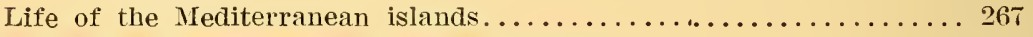

Second Glacial stage--Sixonian. Mindel, Kansan.................. 268

Second Interglacial stage-Mindel-Riss...................... 269

Moisture followed by aridity ............................ 269

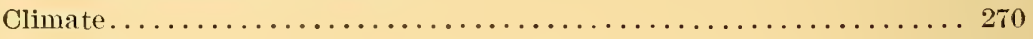

Mammals...................................... 271

Survivals.......................... 271

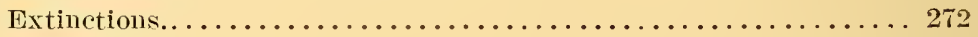

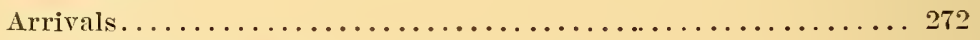

Homo heidelbergensis......................... $2 \pi 4$

Chellean culture and ancient Interglacial fauna.............. 276

Fauna of the Pyrenees, Cantabrian Alps, Spain and Portugal...... 276

Second and third Glacial and Interglacial epochs............... 277

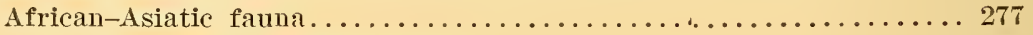

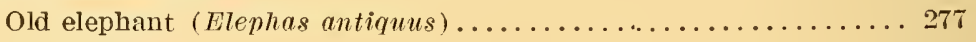

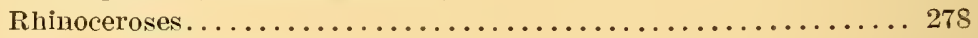

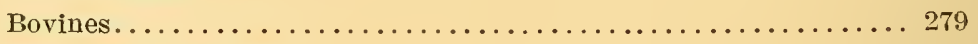

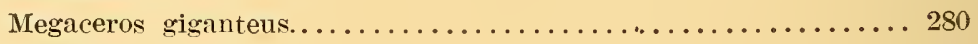

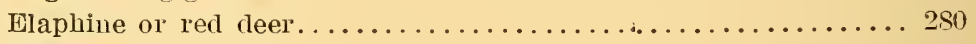

Reindeer................................... 280

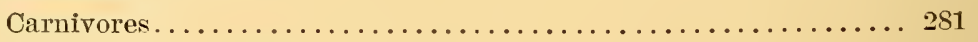

Thiird Glacial stage-Illinoian, Polandian. Riss................ 283

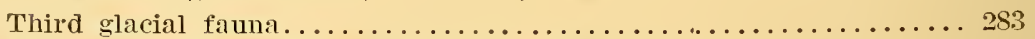

Third Interglacial stage-Riss-Würm, Sangamon............... 283

Climatic changes during the third Interglacial stage............ 284

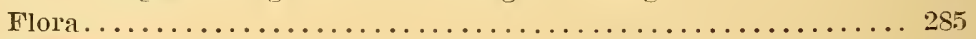

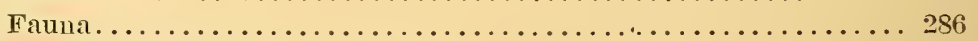

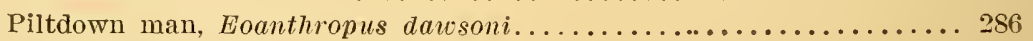

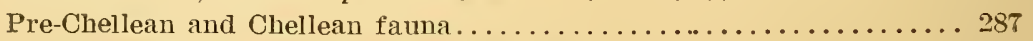

Chellean culture on the "low terraces"................ 288

Grays-Thurrock. Ilford (Essex, England) .............. 288 


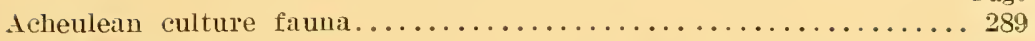

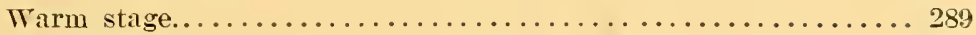

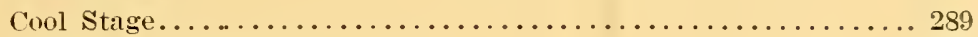

Krapina Neanderthaloid race...................... 290

IIousterian culture, temperate fauna................ 290

Iourth Glacial stage-Wiirm. Mecklenburgian, Wisconsin............ 291

Beginning of the reindeer and cave period................. 291

Period of the final glacial maximum................... 291

Fauna of the fourth glacial stage.................... 292

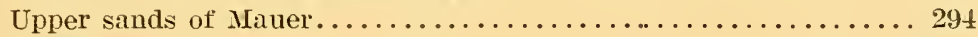

Mousterian Palæolithic culture.................... 294

Neanderthal races............................. 294

Postglacial stage-continuation of upper Palaelithic, reindeer or cave

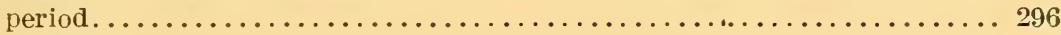

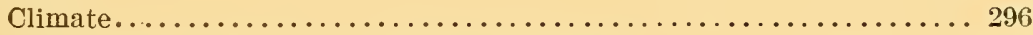

Upper Palæolithic. four or five human races............... 297

Aurignacian, first upper Palæolithic culture stage........... 298

Solutrean, second culture stage.................... 298

Magdalenian, third culture stage and fauna............ 298

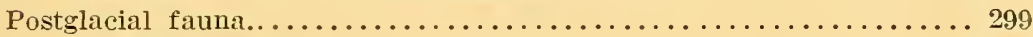

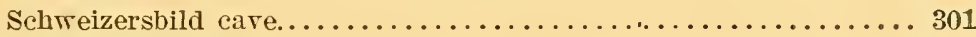

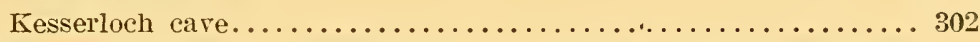

Migrations of the large mammals of the fourth glacial and post-

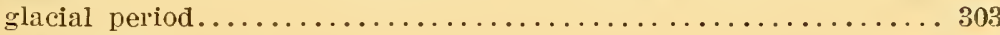

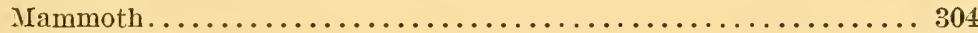

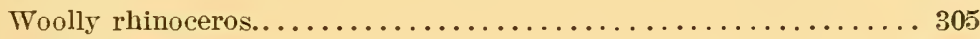

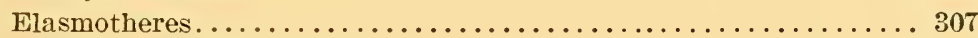

Horses of the Pleistocene.......................... 308

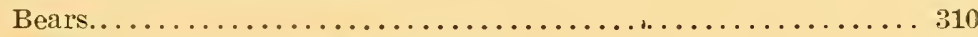

Transition to the European forest stage......................... 311

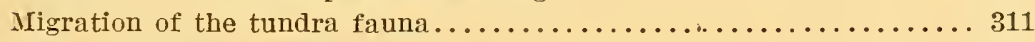

Retreat of the steppe fauna............................. 311

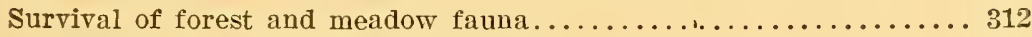

Azilian-Tardenoisian, final upper Palæolithic culture......... 313

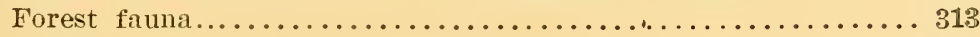

\section{INTRODUCTION}

We observe that the Upper Tertiary closes with a Pliocene northern world rich with life, a world replete with Asiatic and African influence. The Tertiary Period is followed by the Quaternary, or Age of Man, a time of transition and of vast extinctions in Europe and North America through natural causes, as well as of the geographic redistribution of life and establishment of the modern zoögeographic regions. Toward the close of the Quaternary Period man becomes the "destroying angel" and very nearly completes the havoc which Nature has begun. 


\section{CANOZGIC}

Quaternary ................ Age of Man

Tertiary .................. Age of Mammals

We thus enter a new Crnozoic faunal phase, the Seventh. When its transitions are complete the world wears an entirely new and somewhat impoverished aspect: the North has banished all the chief southerly forms and established the five modern zoölogical regions of the Old and New Worlds, namely: Palaaretic, Nearctic, Oriental, Ethiopian, Nertropical.

\section{Seventh Faunal Phase-Quaternary}

IN TIIE NORTHERN HEMISPHERE THE GLACIAL EPOCH. VERY GRADTAL EXTINCTION OR EXPULSION OF SOUTHERN TYPES OF AFRICAN, SOUTH ASIATIC AND SOUTH AMERICAN ORIGIN FROM THE NORTHERX, OR HOLARCTIC REALM. FIRST APPEARANCE IN CENTRAL EUROPE AND NORTH AMERICA OF THE CIRCUMPOLAR TUNDRA FAUNA, IN EUROPE OF THE STEPPE FAUNA. IN NORTH AMERICA EXTINCTION OF THE REMAINING L.IRGE ENDEMIC QUADRUPEDS. THIRD AND FINAL MIODERAIZATION OF EUROPE AND NORTH AMERICA BY THE IIARDY FOREST, MEADOW AND MOUNTAIN RUMINANTS AND THE CARNIVORES.

The grand geologic divisions of the Quaternary in the New and old Worlds are the same, namely, beginning with the Pleistocene and closing with the Holocene.

\footnotetext{
II. Holocene, or Recent Epoch. Mammals of prehistoric and recent
times. Domestication.

I. Pleistocene, or Glactal Epoch.

3. Postgracial. Mammals of tundra and steppe type gradually disappearing or retreating. Mammals of existing north temperate type multiplying.

2. Glacial. Period of successive glacial advances and intergiacial retreats. Mammals of extinct and existing species commingled.

1. Preglacial. Period of the lowering of temperature in the northern hemisphere and modification of plant and animal life.
}

MIEANS OF ESTABLISHING THE TIME DIVISIONS OF THE QUATERNARY

The fluctuations of climate and of the plant and animal life of the Pleistocene are so numerous, so widespread, and so profound that it seems best to introduce the subject by a review of the great time divisions 
together with some discussion as to the period when we should consider that the Quaternary proper begins. The fullness and precision of European faunistic investigation is in very strong contrast to the prelininarr results of American work, and in no other period may we anticipate more reighty inductions from correlation between the history of the old and New Torlds. It is absolutely clear that a final and positive time scale and subdivision of the early Age of Man are not far distant and that the rast labors of European and American geologists, botanists, zoölogists, palæontologists and anthropologists will finally be rewarder? with a harmonious theory of all the phenomena of the Quaternary Period, the determination of the chronology of the various races and an approximate estimate of the duration of the entire Quaternary Period itself. The reader will observe that this correlation, derived from at least five distinct branches of natural science. is based on evidence of four linds.

1. Geological: glacial deposits and erosions, which furnish the chief data for estimates of time.

2. Botanical : plant deposits, alternations of northern, arctic, steppe, temperate and southern floras. which furnish the chief data for estimates of temperature.

$\therefore$ Palieozoölogical : erolution and extinction of mammal and bird life, which furnish the chief divisions of the Quaternary time scale and afford supplementars knowledge of conditions of moisture, temperature and forestation.

4. Anthropological: the successive stages of human culture and implements, the skeletal remains of man, which combined furnish the minor subdivisions and correlations of Quaternary time.

\section{Pliocene and Pleistocene Life of Asia and North Africa}

\section{LIFE OF ASIA}

The region of the rich Tertiary flood plains of India ${ }^{2}$ was one of the main sources of the large mammals which wandered into northern Africa and southern Europe in Pleistocene times; in other words, the large mammals - the elephants, the rhinoceroses, the hippopotami-were all inrading forms from Asia and Africa. The relations between these three geographic regions are, in fact, so close that they might be embraced in a single zoögeographic realm were it not that throughont the Pleistocene the forests and meadows of southern Furope also maintained a northern Eurasiatic fauna which is entirely absent from southern Asia.

\footnotetext{
2 See p. 323 , English edition of "The Age of Mammals."
} 


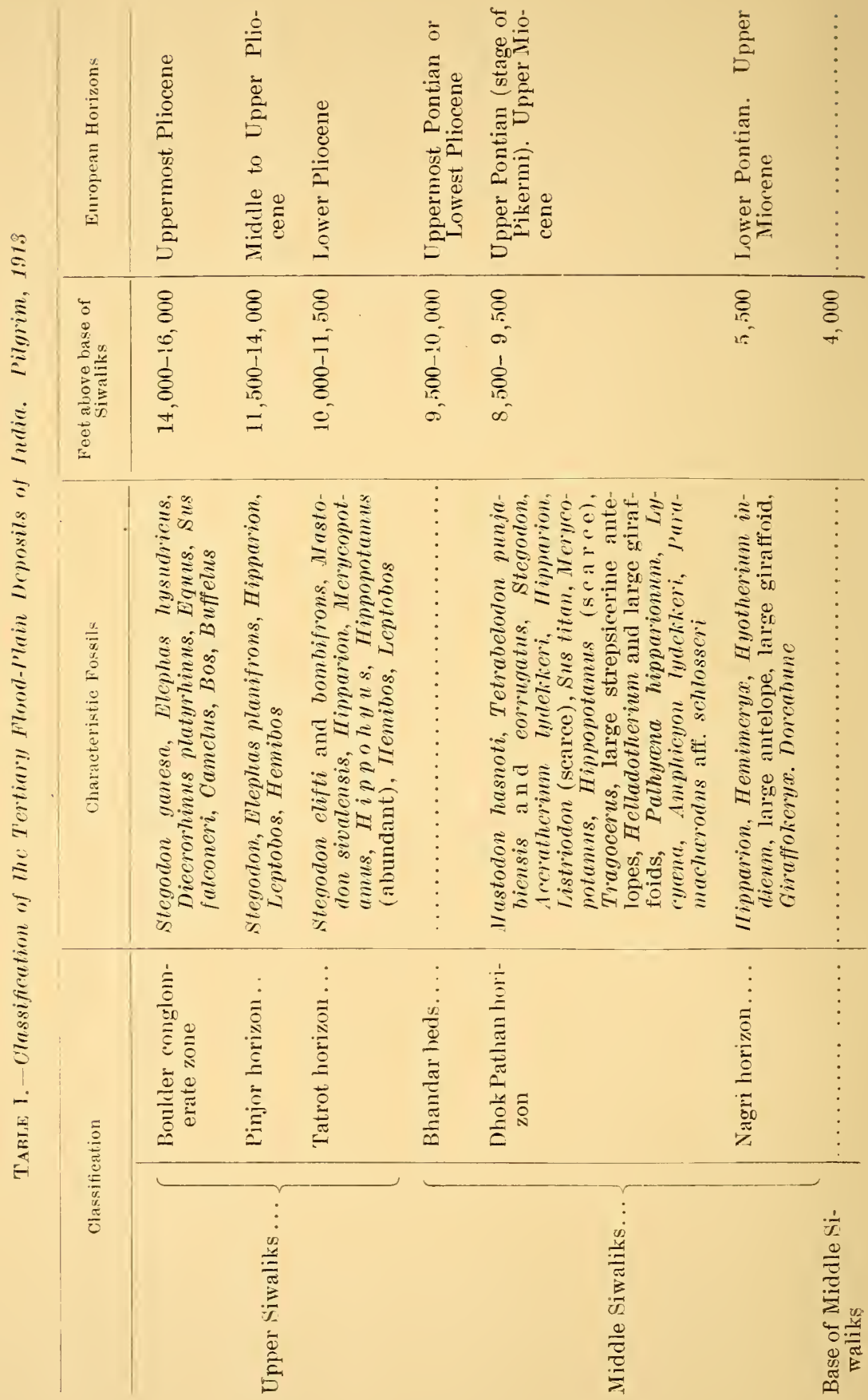




\begin{tabular}{|c|c|c|c|c|c|}
\hline 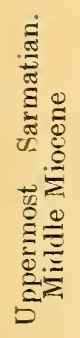 & 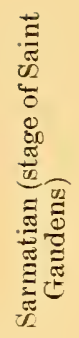 & 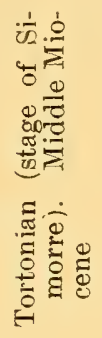 & 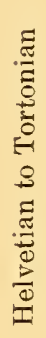 & 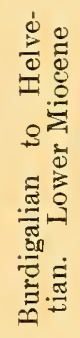 & 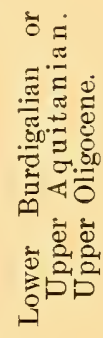 \\
\hline$\S$ & $\begin{array}{l}\mathbb{8} \\
\text { of } \\
\text { of } \\
8 \\
-\end{array}$ & 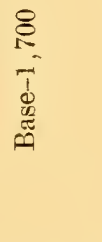 & $\begin{array}{l}\vdots \\
\vdots \\
\vdots\end{array}$ & 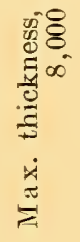 & 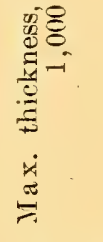 \\
\hline
\end{tabular}

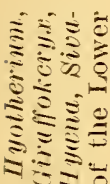

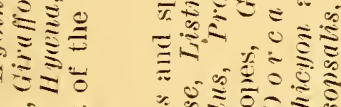

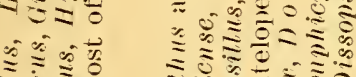
करें

(1)

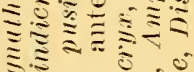

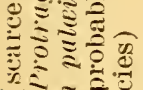

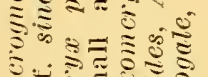

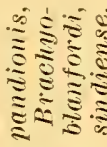

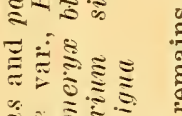

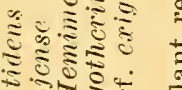

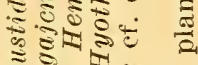

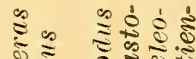

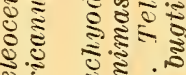

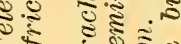

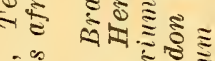

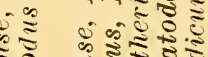

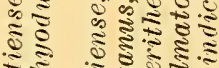

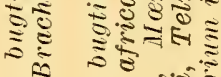
ค. ₹ ज约

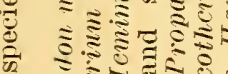

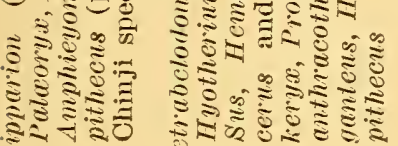

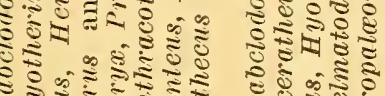

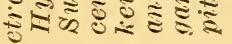

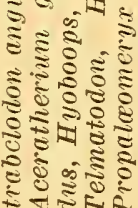

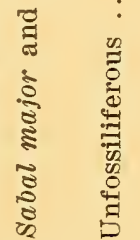
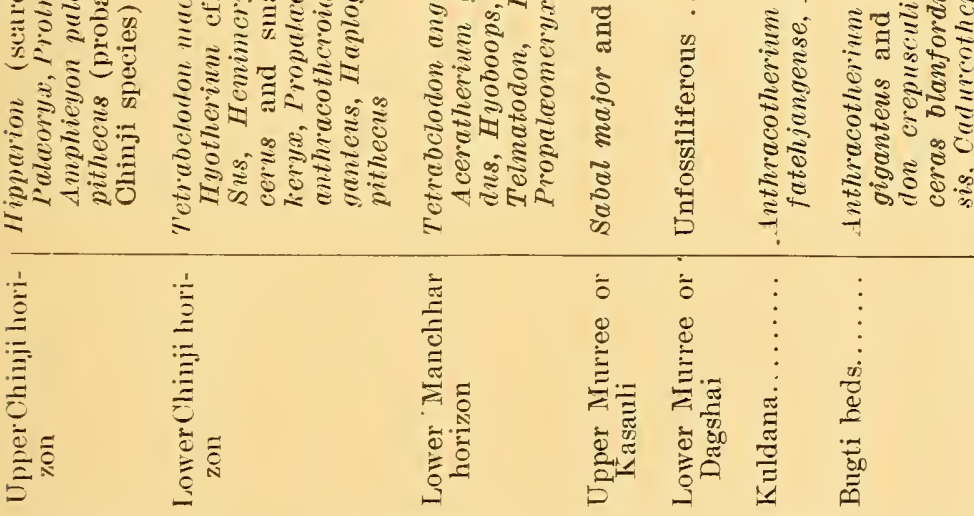

娄
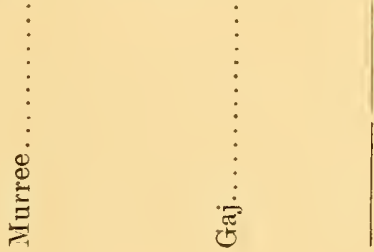
The precise researches of Pilgrim, ${ }^{3}$ published subsequent to the correlation proposed by the author in 1910 in the Pliocene chapter of the "Age of Mammals," have resulted in a new classification and correlation of the Tertiary flood-plain deposits of India which are of the utmost importance and interest to students both of phylogeny and of geographic distribution and migration.

In geologic time the Indian series extends from the Bugti beds, which are of Aquitanian or Upper Oligocene age, to the uppermost Pliocene of the Upper Siwaliks. The correlation with the successive intermediate phases of European life appears to be quite close.

As regards the origin of the Proboscidea, the author discovers in the Upper Oligocene of India animals which he believes resemble the Lower: Oligocene Palcomastodon as well as the Moritherium of the Fayûm deposits of northern Egypt. These animals are referred to respectively as Hemimastodon and Mcritherium. This discovery would favor the hypothesis that the Proboscidea may have originated in southern Asia rather than in Africa. Pilgrim believes that the Mastodon cautleyi of the Upper Miocene of Perim Island gave rise to the Stegodon types of the uppermost Miocene of Pikermi age, namely, to S. clifti and S.bombifrons, from which originated the genus Elephas which first appears in the dominant type Elephas planifrons of Middle to Upper Pliocene times in strata 3,000 feet above those in which the earliest forms of Stegodon occur.

The species E. planifrons is especially important because it has recently been recognized by Schlesinger" in the Pliocene "Belvederschotter" north of Dobermannsdorf near Vienna. The horizon is regarded as of Middle Pliocene or even earlier age. Pavlow ${ }^{6}$ has also recorded the occurrence of $E$. planifrons from beds in Bessarabia which are regarded as of Lower Pliocene age. In the Upper Pliocene of Furope occurs Elephas meridionatis which is regarded as a descendant of E. planifrons, while in the Tpper Pliocene of India occurs the Elephas hysudricus, which Pohlig considers as a geographic variety of the European E. meridionalis. In the uppermost Pliocene of India also oceurs the Dicerortimus platyrhinus, which is believed to be closely related to the D. etruscus of the Upper Pliocene of the Tal d'Arno of Ttaly.

Some authors mistakenly regard the "Altelephant" (E. antiquus) of

\footnotetext{
${ }^{3}$ Pilgrim, GUy E. : "The Correlation of the Siwaliks with Mammal Horizons of Europe." Records, Geol. Surv. Inaia, Vol. xliii, Part 4. pp. 264-326, 1'l. 26. 1913.

4 See Life of Southern Asia, pp. 323-332, "Age of Mammals."

5 Schlesingre, PAUl: "Studien über die Stammesgeschichte der Proboscidier," Jahrb. d. k. Geol. Reichs., Vol. 62, pp. 87-182. Vienna, 1912.

"Pavlow, Marie: "Les éléphants posttertiaires de diver'ses localités en Russie," Ana. gêol. et mineralog. de la Russie, vol, xi, pp. 171-174. Moscou, 1910.
} 
the European Pleistocene as related to $E$. hysudricus of India, but Pilgrim and Pohlig rightly compare $E$. antiquus with the Narbada elephant (E. namadicus), which first occurs in the Pleistocene of Asia. In fact, it is not known whether the phylum of $E$. antiquus, which is quite distinct from that of $E$. planifrons-E. Meridionalis, originated in Asia or in Africa.

To sum up, among the contributions of southern Asia to the Pliocene and Pleistocene fauna of Europe are the following:

Elephas planifrons, entering Europe in the Pliocene, related to the Elephas meridionalis, the southern elephant.

Elephas hysudricus.

Hippopotamus. $H$. javadicus, related to $H$. major.

Bison sivalensis. the short-skulled bison, related to Bison priscus.

The long-skulled 7,eptomos. related to the L. etruseus of the Val d'Armo and Bos primigenius of the First Interglacial Stage.

The Sumatran type of rhinoceros, Dicerorhinus platyrhinus, related to $D$. etruscus and $D$, merchii.

T'he hyæenas, related to $H$. crocuta, the spotted hyæna, and $H$. striata, the striped hyæna.

The horse. Equus sivalensis, related to the Arab, or desert type of Europe.

Among the mammals which did not find their way from Asia into western. Europe are the camels and the various giraffoids. The absence of the antelopine members of the Bovidæ is also a very characteristic feature of the Pleistocene of Europe as contrasted with their abundance in Asia and their presence in diminished form and numbers in the Upper Pliocene of Europe.

\section{LIFE OF NORTH AFRICA}

It would appear that in Lower Pleistocene times when there were broad land connections between Europe and Africa the latter continent contributed to Europe some of its indigenous mammals and others which had been derived originally from Asia. It is natural to suppose that the hyæna and hippopotamus, now so characteristic of Africa, entered Europe either from Asia or from the north African region. With these animals may have come the lion (Felis leo) and the "old elephant" ( $E$. antiquus), which is a primitive offshoot of the same stock that gave rise to the African elephant (Loxodon africanus).

The observe that in Lower Pleistocene times north Africa is still distinctively a part of the Ethiopian Region, closely connected with central and southern Africa in its fauna. Throughout the Lower Quaternary the fauna of north Africa is also closely related to that of Asia. Morenver it has a number of species in common with the Quaternary fauna of 
Europe, including those noted below which came into Europe from Africa. The contrary theory of the relative geographic isolation of Africa and Europe in Quaternary times originated with $\mathrm{Pomel}^{7}$ as the result of his exhaustive review of the entire fauna of north Africa. He concludes that since the resemblances between the European and north African faunas are rare and often doubtful, the two continents were for long periods separated by the Mediterranean Sea and Straits of Gibraltar.

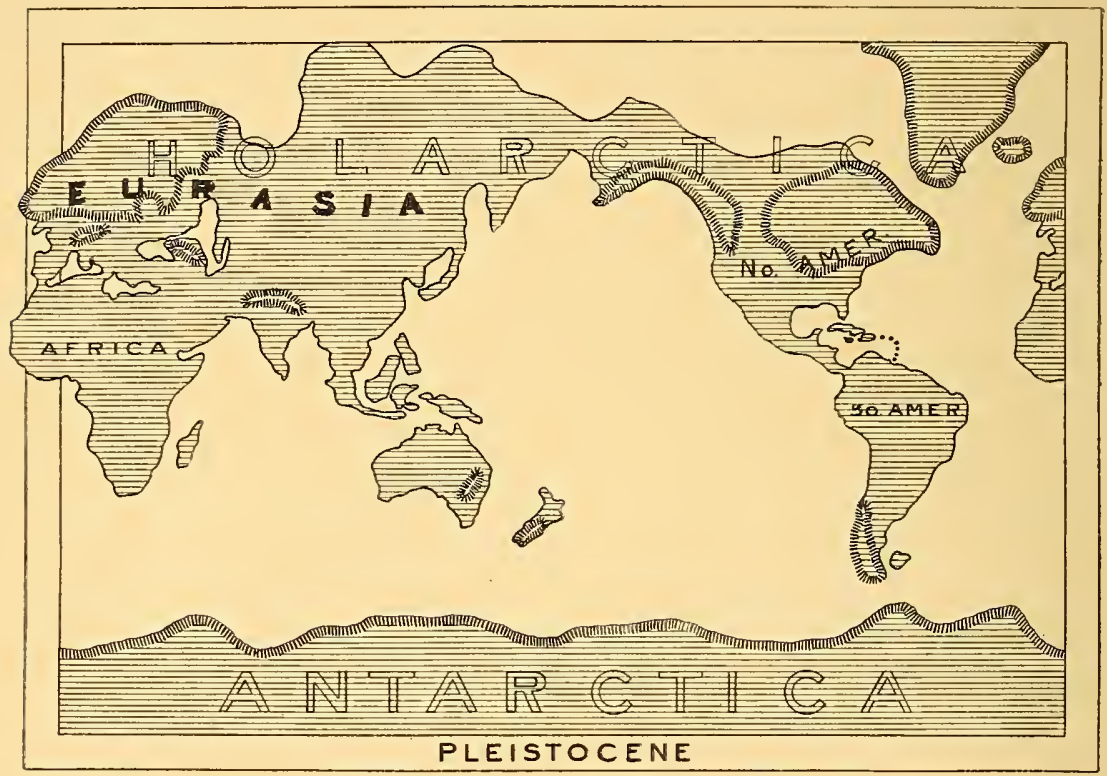

Fig. 1.-Pleistoccne, or Ice Age

A period of maximum total elevation facilitating free migrations and invasions of life, culminating in the Glacial epoch, and followed by a prolonged depression. Portions of northern Europe and the coasts of North America greatly depressed. Then a period of reëlevation. Rearranged after W. D. Mathew, 1nos.

Climate.-At the beginning of the Quaternary Period north Africa was characterized by abundant rainfall which led to the formation of great alluvial or flood-plain depositions. In the Barbary and Sahara regions the life was closely similar to the grand plateau life of equatorial Africa at the present time, including elephants, rhinoceroses, zebras, wild asses, giraffes, wild cattle, buffalo, antelopes. gazelles, gnus, elands, hippopotami. wart-hogs, lions and hyæuas. The presence of these ani-

"Pomnd, A.: "Les Eléphants Quaternaires." Carte Géol. Algérie, Paléont. Monogr. A]giers, 1895 . 
mals is consistent with the climatic theory of subtropical temperature and alternate dry and rainy seasons.

Tarious phenomena point to increasingly long periods of drought and progressire secular desiccation of this great region as the Pleistocene adranced, resulting in the partial extinction and partial migration of the great equatorial life into central and southern Africa.

Eurasiatic Invasion.-At the close of the Quaternary the bear ( $C$ rsus), as a characteristic forest-dweller, requiring a moist climate, became extinct, while the Eurasiatic deer, wild sheep, wild boar, smaller mammals of European type, survived and established for this region its present affinity with Europe and its Palæarctic fauna. We must account for this northerly, or Eurasiatic, fauna of north Africa as having entered the continent during the latter part of the Pleistocene Epoch and as surviring in the forested regions of present and prehistoric times so as to unite northern Africa closely with modern and prehistoric Europe. North Africa thus becomes a part of the Palæarctic Region.

Thus in no region of the world have more profound changes occurred during and since Pleistocene times than in Africa north of the Sahara Desert.

Sources of the Pleistocene African Life.--It is premature to attempt to ascertain the original sources of all the varjous members of this imposing assemblage of mammals. There remains always a great element of doubt which can be eliminated only by the discovery of the complete Cænozoic history of Asia and Africa. It would appear probable from our previous studies that the several continents contributed to the remote original ancestry of the African fauna somewhat as follows:

Africa or Asia, elephants and mastodons.

Northern Eurasia, deer and bear, wild sheep, wild boar.

Southern Eurasia, wild cattle and buffalo.

North America or northern Eurasia, rhinoceroses. various Equirtre, camels.

The most comprehensive comparison of the fauna of Africa and Europe is that of Stromer, ${ }^{s}$ in which the entire fauna of Europe and north Africa, including the Reptilia and Mammalia, is compared from Lower Eocene to Pleistocene times. This author observes ${ }^{9}$ that during the middle period of the Tertiary the mammal fauna of southwestern Europe, western Asia, India to China, partook of the tropical or subtropical

\footnotetext{
${ }^{8}$ Stromer, Ernst : "Über die Bedeutung der fossilen Wirbeltiere Afrikas für die Tiergeographie." Verhandl. d. Deutsch. Zoöl. Gesellschaft, pp. 204-218. 1906.

"STrourer, ERvst: "Die einstige Verbreitung afrikanischer Säugetiere." Naturwissenschaftliche Wochenschrift. N. F., X Band; der ganzen Reihe, XXVI Band, No. 51, pp. 814-816. Lec. $17,1911$.
} 
character of the African high plateau fauna, rich in antelopes, giraties, zebra-like ancestors of the horse, elephants, rhinoceroses, hyænas and apes. Late in Diluvial times in Europe numerous representatives of what we now consider a tropical African fauna, including hippopotami, lions, hyænas and apes, were widely distributed.

Asiatic and European Affinities. - The total assemblage of the Pleistocene life of north Africa may be summarized as follows from Ponel:

Man (Homo, Late Pleistocene)

Mastodon ( Early Pleistocene only)

Elephants (sereral species related both to Loxodon and to Elephas)

Rhinoceroses (two species of the African, or Diceros type)

Hipparious, zebras and asses

Camels

Giraffes (Libytherium, Giraffa)

Wild cattle $(B \circ s)$, three species

Buffalo (Bubalus)

Dwarf antelopes, gazelles, gnus, oryx, nagor: elands

Hippopotami

Wild boar (Sus)

Wart hogs (Phacochorus)

Lions (two carern species)

Hyænas (spotted and striped)

Jackals (Canis aureus), India

Macaques (of northern origin)

Deer (of the Cerrus type, one species !

Eear (of the Helarctos group)

Wild sheep and goats (Ovis palcotragus, O. promaza)
A noteworthy distinction between north Africa and Europe is the survival in north Africa of the mastodons throughout early Pleistocene times; also of several species of hipparions side by side on the plains of Numidia with the early north African horses ${ }^{10}$ or zebras. Both the mastodons and the hipparions are absent in the Pleistocene of Europe.

WVe may now leview the life of north Africa itself in Pleistocene times. Six species of elephant oecur, including the mastodons, the southern mammoth (E. meridiona7is), and the "old elephant" ( $L$. antiquus). The most characteristic and widespread elephant ( $L$. atlanticus) belongs to the African subgenus Loxodon while differing from the recent African elephant ( $L$. africanus) in several points. The latter species only occurs in the recent deposits of the latest prehistoric period.

Similarly the two species of rhinoceros (D. mauritanicus, D. subinermis) resemble the modern African types, but there is nothing to indicate the presence either of the modern African "black" (D. bicornis) or "white" (D. simus) species.

Among the Pleistocene horses, in addition to the surviving hipparions and the species (E. numidicus) related to the Val D'Arno type of Europe, there is a third species ( $E$. mauritanicus) which exhibits tooth characters of the recent zebra. Thus there is every reason to believe that

\footnotetext{
${ }^{10}$ Boule, M. : "Observations sur quelques cquidés Fossiles." Bull. Șoc. Gêl. France, Ser. 3, vol. xxvii, pp. 531-542. 1899 .
} 
in Pleistocene times ancestors of the zebras, which are now confined to equatorial Africa, extended to the extreme north of the continent. To the same period belongs a wild ass very similar to the Ethiopian ass (E. asinus), an animal which survived in this region until exterminated by the Greeks and Romans, and is now confined to the highlands of Abyssinia.

Among the Artiodactyla the presence of camels ${ }^{11}$ (C. thomasii) in Palæolithic Pleistocene times and even in deposits of Neolithic age $(C$. dromedarius) is extraordinarily interesting. There is no evidence as to domestication. The earlier of these two camels of ancient Libya had longer legs and was of heavier build than the dromedary. The rare remains of the later form, probably identical with the recent dromedary, may be those of a race which was already emigrating or becoming extinct. The presence of the camel is one of the most convincing proofs of connection of this fauna with that of the Upper Siwaliks of southern Asia, and thus of North America.

Especially significant of Asiatic and Siwalik affinity are the Pleistocene cattle and buffaloes of north Africa, including contemporary species of Bos, all belonging to late Quaternary or to the Neolithic age, partly domesticated, and with remote resemblances to the Pleistocene cattle of France and Spain. Similar Asiatic affinity is found in the remains of a buffalo (Bubalus antiquus) allied to the existing Indian form; this was a powerful beast which presumably lived in herds, frequenting grassy plains and swampy districts, and in its presence here we seem to find confirmation of what geology teaches us in regard to the dampness of the Quaternary climate. The disappearance of the buffalo from north Africa at the commencement of the Recent Period was no doubt due to the increasingly dry conditions, and partly to destruction by man.

The great number and variety of antelopes is most astonishing in this legion, which at present is inhabited only by the gazelles (Gazella), the hartebeests (Bubatis) and addax antelopes (Addax). The Pleistocene fauna includes gnus (Connochotes), several species of Bubalis still represented in the Barbary States, an aberrant form (Oreonagor), related to the nilgai of India, nine species of gazelles (Gazella), the oryx (Oryr), the nabor (Cerricapra redunca), several large elands (Oreas), such as now inhabit south Africa, as well as dwarf antelopes (Cephatophus). Beside these plains and desert types of ruminants, the hills were covered with wild sheep (Ovis palootragus) very similar to the existing Barbary sheep, as well as goats (Ovis promaza).

11 Pomel, A. : "raméliens et Cervidês," Carte Géol. Algêrie, Paléont. Monogr. Algiers, 1893. 
In the rivers there lived in early and later Pleistocene times a series of species of hippopotami (H. hipponensis, H. sirensis, H. icosiensis) leading to a form ( $H$. annectens) related to the existing Nile hippopotamus. There are also two types of wild boar (Sus), and more abundant than these were the wart-hogs (Phacochcrus) found in the cares and alluvial deposits of Barbary.

Preying upon these Herbivora were lions, leopards and hyænas, which are compared by Pomel with Pleistocene cave forms of Europe. 'There are also jackals, wolves. the ichneumon and, possibly, a polecat.

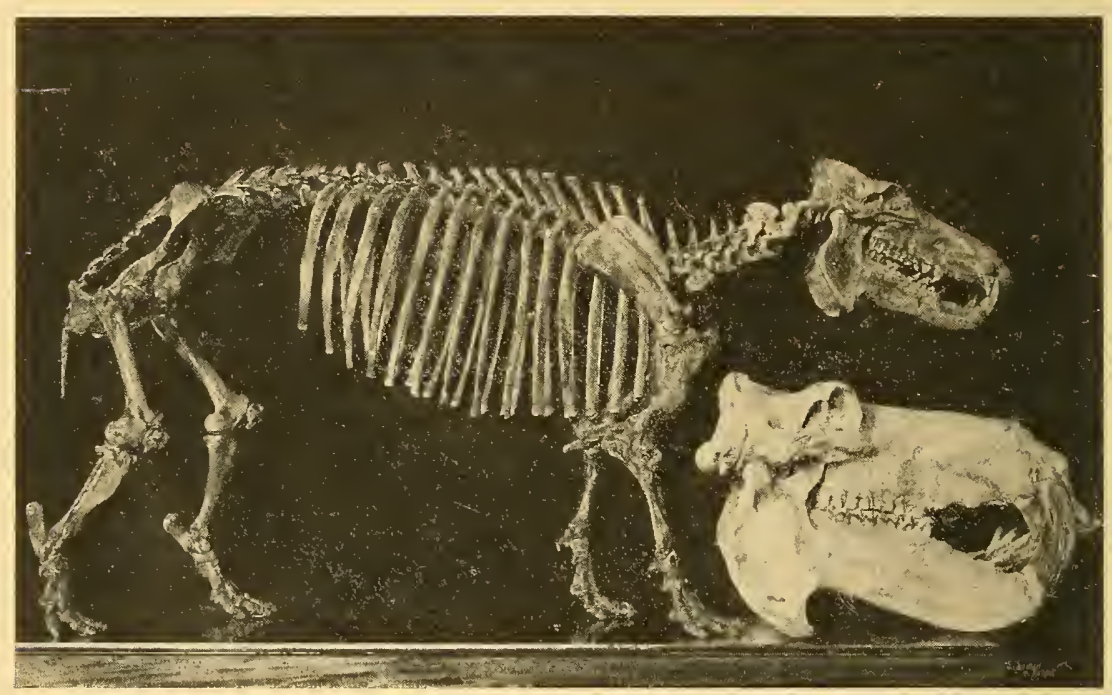

FIG. 2.-Skeleton of the Pleistocene pigmy hippopotamus of Madagascar, Hippopotamus madagascariensis, together with a skull of the recent hippopotamus, H. amphibius

In the American Museum of Natural History.

African-European Distribution.-Of this imposing list the following types occur both in Africa and in the Lower and Middle Pleistocene of Europe, the species being similar if not in some instances identical.

Southern elephant (E. meridionalis). which is also found in Pliocene and early Pleistocene deposits of Europe.

bilephants similar to $E$. antiquus of Europe and its dwarf representatives in Malta and other Mediterranean islands are found in the Upper Pleistocene deposits of north Africa.

Long-headed rhinoceroses. It would appear probable that the woolly rhinoceros (D. antiquitatis) which is closely related to the "white" rhinoceros (D. $\operatorname{sim} u s)$ originated in Africa, but no animal resembling it has been discovered in the African Pleistocene. 
One of the Pleistocene horses of north Africa (E. numidicus) is closely similar to the Upper Pliocene $E$. stenonis of Europe.

With these animals may have come the lion (Felis leo) which was widely spread over southern Europe.

Hrænas. The striped (H. striata) and spotted hyænas (H. crocuta) are common to Europe.

Bears. The bear (Ursus lybicus) found fossil in Algeria seems to belong to the Helarctos group, possibly derived from the small $U$. etruscus of the European Pliocene and now represented by the Malayan sun bear.

Machærodonts. Recently (Stromer) sabre-tooth tigers have been discovered in Pleistocene Egypt.

Primates. The primates are represented by the macaque (Macacus), not very different from the existing forms which frequent the region of the Straits of Gibraltar. In Pleistocene times the macaques ranged northward into southern France (Harlê).

Suillines. Wild boar (Sus) may have affinities with the Pliocene types of Europe.

With the exception of the above list, there is little in common between the large fauna of north Africa and that of Europe in Pleistocene times.

\section{AFRICA IN PALEOLITHIC AND NEOLITHIC TIMES.}

Giraffes very similar to the recent African giraffe ( $C$. giraffa) have been found in mid-Pleistocene deposits associated with Palæolithic stone - implements of the Chellean type. ${ }^{12}$ Industry ${ }^{13}$ similar to the Chellean but not necessarily of the same age is found in Africa from Egypt to the Cape. Giraffes are also depicted in rock drawings of Neolithic age in Algeria.

In Neolithic times there existed at least one species of deer, whereas at present there are two kinds of deer, the red and the fallow, ${ }^{14}$ in north Africa, both undoubted Eurasiatic migrants.

The prehistoric men of the Barbary States apparently obtained and domesticated the horse, species of sheep and several dogs, and left many sketches of animals on the rocks of the legion. ${ }^{15}$

\section{Pleistocene or Glaciat Epoch ix Europe}

After the establishment of the single glacial theory by Charpentier and Louis Agassiz (1836-1840), there gradually developed in Europe and

12 Pallary, P.: "Note sur la Girafe et le Chameau du Quaternaire Algérien." Bull. Soc. Géol. Erance, Ser. 3, Vol. XxVIII, pp. 908-909. 1900.

13 Obermaier, Hugo : "Der Mensch der Vorzeit, Band I. of Der Mensch aller Zeiten." Alleg. Verlags-Gesellsch. m. b. h. Berlin, Munich, Vienna, 1912.

14 See Lydekger, Richard: Deer of all Lands. The North African red deer (Cervus elaphus barbarus) is smaller than the European race. Evidence on the range of the com. mon fallow deer (Cervus dama) in northwestern Africa is not very full.

15 See Ромег, '93, '94, '95, '96, '97, '98. 
America the hypothesis of several glacial advances of varying duration and severity alternating with interglacial temperate periods during which the ice retreated and conditions of climate prevailed which in some instances were even milder than the present in the same latitudes.

As early as 1856 Morlot observed a relatively warm flora between two Swiss glacial deposits at Diirnten, and he subsequently advanced a theory of three glacial stages. James Geikie (1871-1894) developed the hypothesis of a succession of six glacial and five interglacial stages and climates. In 1883 Boule from his observations along the Mediterranean coast main-

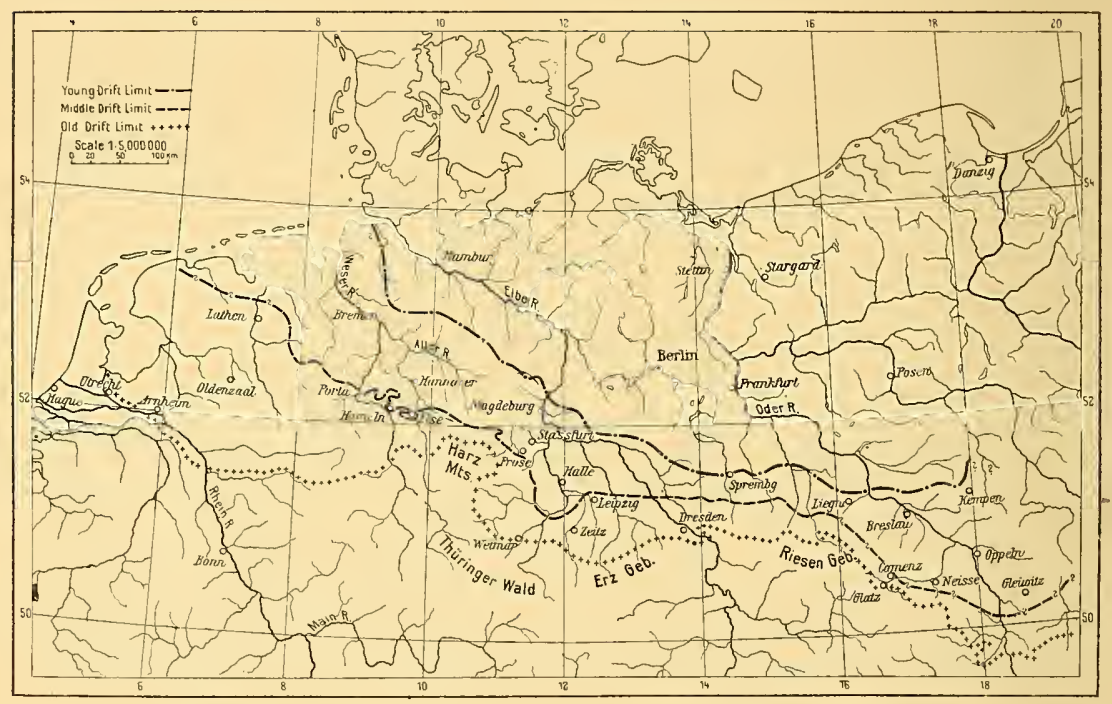

FIG. 3.-Glacial map of northern Germany and the Tetherlands

This map shows the drift and terminal moraines of Glaciations I-II, Scanian + Saxonian (old drift), III Polandian $=$ Riss (middle drift), IV Mecklenburgian $=$ Würm (upper drift). After Leverett, 1910.

tained that there is evidence of three great glacial advances, the first falling within the close of the Pliocene Epoch, the second falling properly within the Pleistocene. The firm foundation of the quadruple theory in Europe was laid, however, by the researches of Penck and Brückner ${ }^{16}$ in the Alpine region, published in 1909. According to this classic work the entire Glacial Epoch is assigned to the Pleistocene or Quaternary Period. Its deposits include the entire "Diluvium" and "Drift" of earlier geologists.

All the river gravels. boulder-clays and moraines of the Glacial Epoch

16 Penck, Alerecht, and Brẗckner, Edouard: Die Alpen im Eiszeitalter. III. Die Eiszeiten in den Sudalpen und im Bereich der Ostabdachung der Alpen. Leipzig, 1909. 
are of later date than the marine Pliocene deposits of southern Europe. Before any of these glacial deposits occurred there was an elevation of the marine Pliocene strata along the southern Alpine borders from sea level to a height of from $300-500 \mathrm{~m}$.; there also occurred erosion of these marine strata by rivers. Thus in the valley of the Po there is a considerable time interval between the closing marine conditions of the Pliocene and the opening Pleistocene conditions. In the valley of the Rhone also there is a marked interruption between the strata of the Pliocene and of the Glacial epochs, the latter overlying the strata recognized as Upper Pliocene, which in turn overlie the marine Pliocene. ${ }^{17}$

This interval between the Pliocene and Pleistocene corresponds with rery important changes which occur in the mammalian life of Europe, namely, in the extinction of many characteristic Pliocene mammals, such as the anthropoid apes, the antelopes and the mastodons.

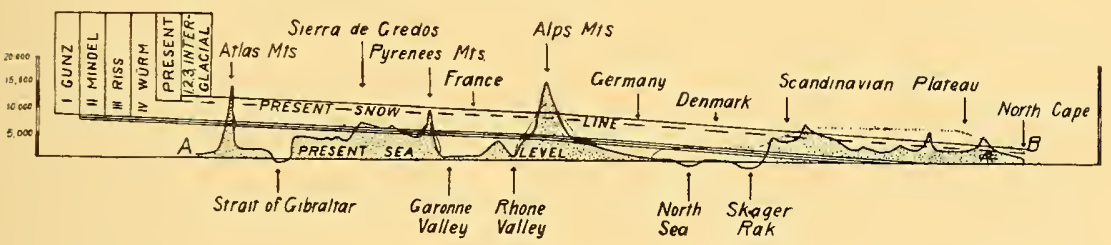

PROFILE OF PAST AND PRESENT SNOWLINES AND CLACIERS OF EUROPE

F1G. 4.-Theoretic snow levels during the Glacial Epoch

Prepared under the direction of the author by Chester A. Reeds from data given by J. Geikie, Penck, Brüchner, Leverett and Stieler's Hand-Atlas, December, 1914.

The traces of four different glacial advances and retreats observed around the northern slopes of the Alps by Penck and Brückner ${ }^{18}$ were followed with their "river drifts" and moraines down the Danube to the neighborhood of Vienna; they were found to be clearly marked in the region of the upper Rhine and of the Rhone around Lyons, and distinguishable both by the greater or the less extension of their borders and by the greater or less erosion which has occurred in the intervals between their successive depositions. These four advances were named respectively the Günz, the Mindel, the Riss and the Würm.

As an instance of the disparity between the duration of these several glacial advances with the accompanying descent of the ice and snow line, the old moraines of the Riss or third glaciation form a girdle around the more recent Würm or fonrth glaciation, proving that the Riss was not

\footnotetext{
${ }^{17}$ Op. cit., pp. 654-655.

${ }^{18}$ Op. cit., p. 47 .
} 
only a more extensive glaciation but that the snow line was $100 \mathrm{~m}$. lower. It is also estimated that the climate of the Riss was one-twelfth more severe than that of the Würm.

In northern Germany only three great glacial advances are recorded, while still farther north, in Scandinavia, there was in a sense only one Glacial epoch, since the ice cap never retreated so far as to permit of interglacial deposits. This is in accordance with the anthropological fact that only toward the close of Postglacial times does Scandinavia show traces of human habitation in the arrival of the Neolithic men; whereas in France and Germany there is evidence of human habitation as early as the Second and Third Interglacial Stages.

In the meantime American geologists have also discovered similar proofs of four successive glacial advances and more temperate interglacial stages. The correlation of these conditions in the New and Old Worlds suggested by Penck, Chamberlin and others has recently been reviewed with great precision by Leverett, ${ }^{19}$ to whose work we shall frequently refer. The most recent results of geologic and anthropologic correlation with some original modifications are graphically presented in the accompanying diagram (Fig. 5) by the author and Reeds. ${ }^{20}$

The river terraces are of great importance both in geology and in anthropology. In general the "high terraces" belong to the earlier glaciations and the "low terraces" to the latest. Thus the "high terraces" of the Alpine region belong to the Riss or glaciation III; in the valley of the Rhine the "high terrace" is visible near Bâsle; the "low terrace" of the Würm or glaciation IV occupies vast surfaces on the upper Rhine and contains a mammoth (E. primigenius) fauna. The "high terraces" in the Paris basin reach $30 \mathrm{~m}$. above the level of the Seine, while the "low terraces" are only $5 \mathrm{~m}$. above the level of the Seine and subject to floods; the "high terraces" in the valley of the Seine contain the First Interglacial ( $E$. meridionalis, $E$. stenonsis) fauna, while the "low terraces" of the Seine and of the Somme contain the Second and Third Interglaciai faina (E. trogontherii, E. antiquus, and D. merckii).

\section{DURATION OF THE PLEISTOCENE}

The Pleistocene was estimated by the American geologist Dana (1874) to be equal to about one-fourth of the entire Cænozoic Era, i. e., 700.000 years. By Ward (1885) and Williams (1895) it has been estimated at

${ }^{10}$ LeVERETT, FrANK : "Comparison of North American and European Glacial Deposits." Zeitschr. f. Gletscherkunde, Vol. iv, pp. 241-316. 1910.

20 Reeds, Chester A.: Dr. Reeds has prepared the climatic curve from data furnished by l'enck, Leverett, Taylor, Chamberlin, Salisbury, Geikie, Schmidt, Coleman and Osborn. Dated October, 1914. 


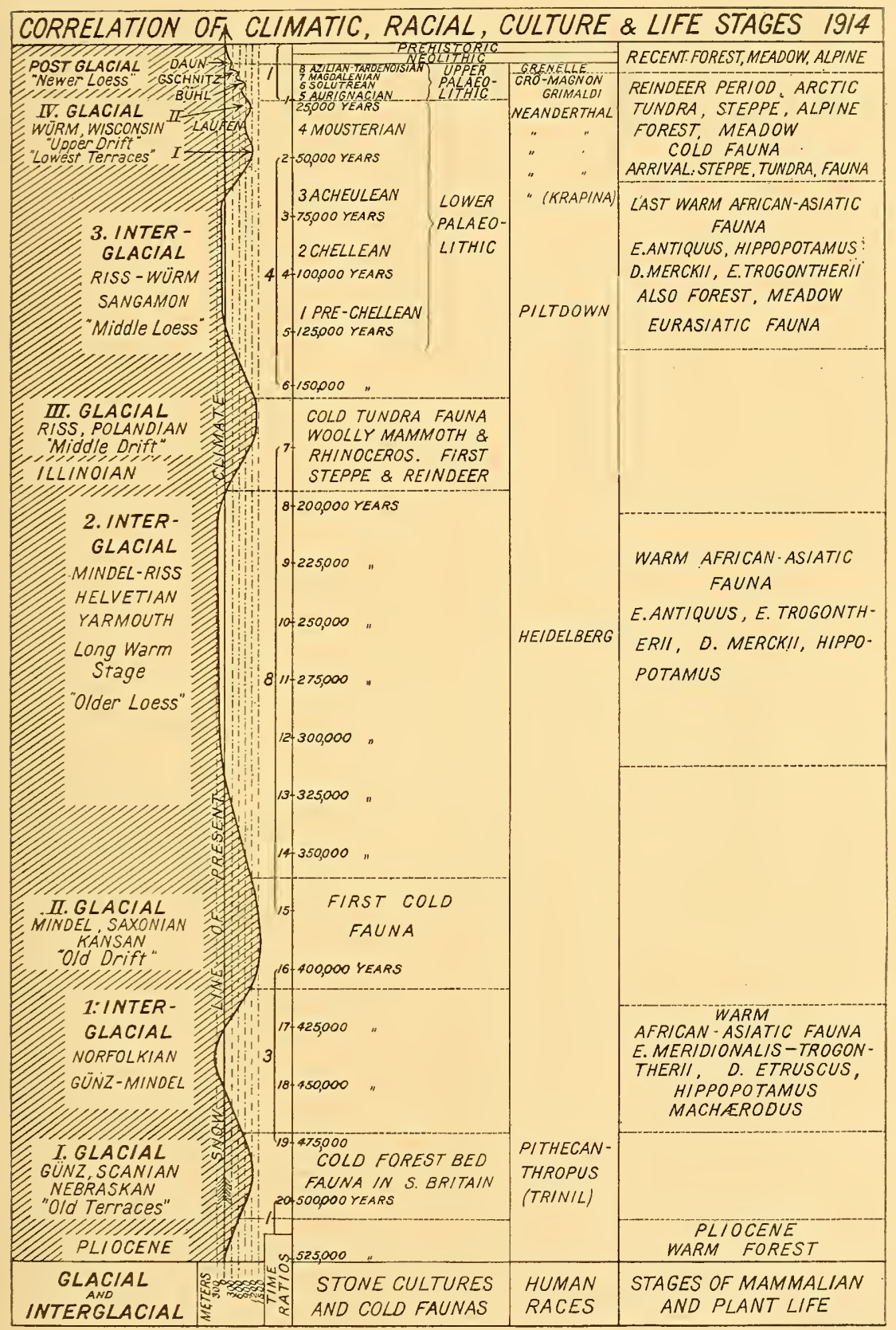

Frg. 5.-Divisions and contemporaneous events of the Glacial Epoch

Prepared under the direction of the author by Chester A. Reeds from data observed and correlated by J. Geikie, Penck, Chamberlin, Salisbury, Leverett, Schmidt, Coleman and Oshorn. October, 1914. 


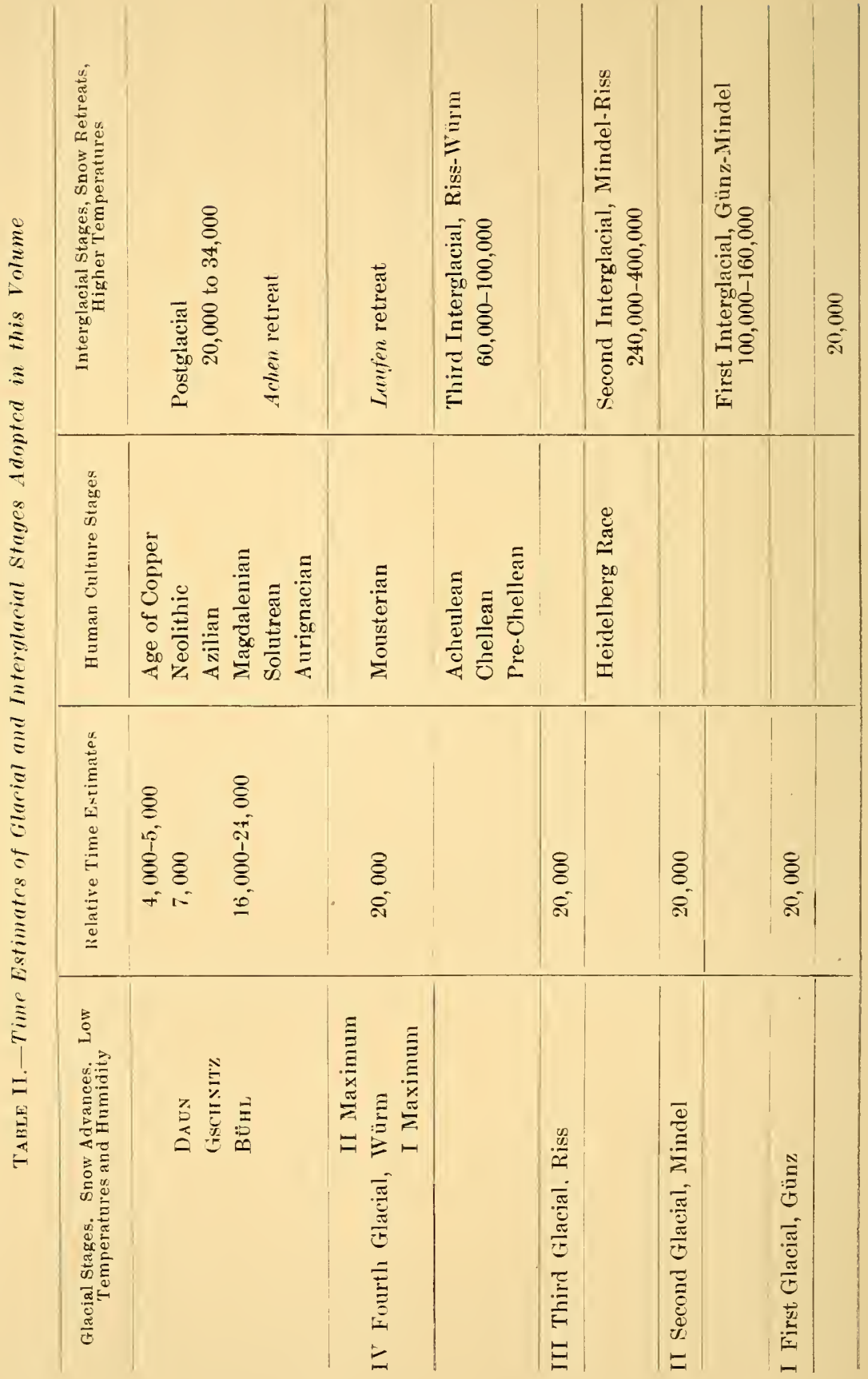


(ne-third the entire Camozoic, i. e., 1,000,000 years. If with Wallace we accept Croll's theory and estimate, the last glacial advance would date back to the last perior of great eccentricity of the earth's orbit, namely, 200,000 years, but this we now consider excessive. The following figures show the rariations of opinion on this subject and the two opposite tendencies of greatly expanded or greatly abbreviated estimates of Pleistocene time :

\begin{tabular}{|c|c|}
\hline Lyell, "Antiquity of Man”. . . . 1863 & 800,000 years \\
\hline Upham ............... 1898 & 100,000 \\
\hline Walcott ... & 400,000 \\
\hline Sollas .. & 400.000 \\
\hline Penck . . . . . . . . . . . . . . . 1909 & 520,000 to $\$ 40,000$ vears \\
\hline
\end{tabular}

The rery high estimate of $\$ 40,000$ years made by an eminent and usually conservative authority such as Penck appears excessire unless we are to expand our estimates of Tertiary time (see p. 63) to $20,000,000$ years and of the pre-Tertiary into hundreds of millions of years.

All the arguments for the briefer estimates of Pleistocene time have recently been brought together by Tright. ${ }^{21}$

Antiquity of Man.- Tast interest attaches to this duration problem in connection with the antiquity of man. In the calculations of Penck ${ }^{22}$ the time since the Fourth or Würm glaciation has been used as a measureunit to calculate the length of the previous glacial and interglacial periods. It is beliered that since the climax of the Würm glaciation from 20,000 to 34,000 years have elapsed. Geologic, prehistoric and historic erents since the close of the last glaciation make this estimate appear not excessive. In regard to the previous time intervals, the author does not pretend to give an absolute age estimate, but simply a survey of the relative magnitude of the time periods with which we are dèaling.

The unit of measurement is Postglacial or post-Würm time which Penck ${ }^{23}$ estimates at 20,000 years. On the basis of this estimate the time (520,000 years) covered by the whole Glacial Epoch is relatively distributed as follows :

21 Wright, G. Frederick: The Ice Age in North America and its Bearings upon the Antiquity of Man. 8vo. Bibliotheca Sacra Co. Oberlin, 1911.

22 Pexck, A.: "Das Alter des Menschengeschlechts." Zeitschr. Ethnol., No. 3, pp. 390-407. 1908.

z Penck, A., and Brïckyer. Edocard: "Die Alpen im Eiszeitalter. Dritter Band, Die Efszeiten in den Sudalpen und im Bereich der Ostabdachung der Alpen." 8vo. Tauch. nitz, Leipzig, 1909. (pp. 1153-1176, "Chronologie d. Eiszeitalters in d. Alpen." Penck.) 


\begin{tabular}{|c|c|c|c|c|c|}
\hline & & & $\begin{array}{l}\text { Iielative } \\
\text { duration }\end{array}$ & Totals & $\begin{array}{l}\text { Descent of } \\
\text { snow line. }\end{array}$ \\
\hline & & $\mathrm{lni}$ & Years & & Meters \\
\hline & Postglacial, post-Würm hemicycle. & 1 & 20,000 & 20,000 & .. \\
\hline or & Würa Glactation... & 1 & 20,000 & 40,000 & 1,200 \\
\hline & 3rd or Riss-Wiirm Interglacial Stage & 3 & 60,000 & 100,000 & 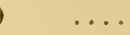 \\
\hline II or & 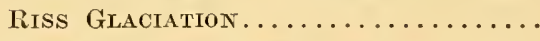 & 1 & 20,000 & 120,000 & 1,250 \\
\hline & 2nd or Mindel-Riss Interglacial Stage & 12 & 240,000 & 360,000 & \\
\hline II or & Mindale Glaciation $\ldots \ldots \ldots \ldots \ldots \ldots$ & 1 & 20,000 & 380,000 & 1,300 \\
\hline & 1st or Güinz-Mindel Interglacial Stage & 5 & 100,000 & 480,000 & \\
\hline I or & GüNz Glaclation....... & 1 & 20,000 & 520,000 & 1,200 \\
\hline
\end{tabular}

The three chief conclusions of Penck are as follows:

1. If the whole Ice Age extended over a period of 500,000 to $1,000,000$ years, the Second very long warm Interglacial Stage, also known as the Mindel-Riss or Helvetian, is reckoned at more than 200,000 vears, while, the final relatively short interglacial stage, the Riss- ITürm, is reckoned at $60,000-100,000$ years.

2. The duration of the Lower Palæolithic culture periods, the preChellean, Chellean and Mousterian, would by this reckoning be much longer than that of the Upper Palæolithic culture periods, the Aurignacian, Solutrean and Magdalenian. Penck estimates that since the beginning of Magdalenian times 24,000 years may have elapsed and since its close about 16,000 years.

3. Compared with these prolonged Palæolithic divisions the Neolithic Stone and Metal periods have occupied an almost unappreciable length of time. If the beginning of the Neolithic lake dwellings is dated about 5,000 to $\%, 000$ years ago we estimate that the beginning of the Copper Age in Europe dates back between 3,000 and 3,500 years; in Africa it is much more ancient.

The human culture stages are arranged above not according to Penck but according to the more recent correlations of Obermaier, Breuil, Schmidt and others.

\section{GEOLOGIC AGE OF THE CULTURE STAGES}

The trend of Palæolithic research lately has been to draw all the human culture periods from the pre-Chellean to the Magdalenian closer together and to reduce the time assigned for their evolution. All the French authorities, led by Boule, Cartailhac, Breuil and Obermaier, are now agreed in assigning the earlier Palæolithic cultures. the pre-Chellean, Chellean and Acheulean, to the Third Interglacial Stage and not to the Second. Schmidt has also lately declared himself in favor of this view after a most exhaustive and valuable investigation of this problem. 
A summary of the correlation presented in this chapter is embodied in the Table of Osborn and Reeds above. A summary of the very diverse opinions on this subject is embodied in the Table of Wiegers below.

A rery strong reason for abbreviating our estimates of the period which has elapsed since the appearance of man of the pre-Chellean culture stage in Europe is found in the relatively unchanged condition of the river valleys of the Somme in northern France and of the Vézère in Dordogne, in which the earliest human cultures occur. The Vézère has not materially changed since Acheulean times. The pre-Chellean, Chellean and Acheulean specimens found in the Somme valley are also connected with the present river system. Both on the Somme and the Marne the Chellean and pre-Chellean cultures occur on the "lowest terraces." Again, there is no faunal break between late Chellean and early Acheulean times nor between late Acheulean and early Mousterian times. The first great faunal break is that produced by the Fourth glaciation.

In favor of Penck's contention as to the earlier geologic age of the Chellean is the occurrence of pre-Chellean and Chellean palæoliths in association with a very primitive mammalian fauna such as is characteristic of Second Interglacial times.

\section{ELEVATION AND SUBSIDENCE OF LAND IN QUATERNARY TIMES}

The relations of the mammals of Europe with those of Asia on the east and Africa on the south were profoundly affected in Pleistocene times by the periods of elevation of the continental shelf, resulting in the creation of new land connections which facilitated migration, or of subsidence which cut off and isolated many migrating forms from their centres of origin and dispersal. The maximum elevation, as represented in the accompanying diagram (Fig. 1), never occurred in all portions of the continent of Europe at the same time, because there were oscillations both on the northern and southern borders of Europe and Asia.

The beginning of the Pleistocene Epoch is one of elevation and is remarkable for the broad land connections between Europe, Africa and Asia. It represents the last stage in that vast community of mammalian life which during Pliocene times distinguished the entire region of Europe, Asia and Africa.

The theoretical relation which elevation and subsidence respectively bear to the glacial and interglacial stages and phenomena is, broadly speaking, as follows:

ELEVATION, emergence of the land from the sea, broad land connections facilitating migration, retreat of the ice caps, periods of erosion of the river valleys and formation of terraces. 


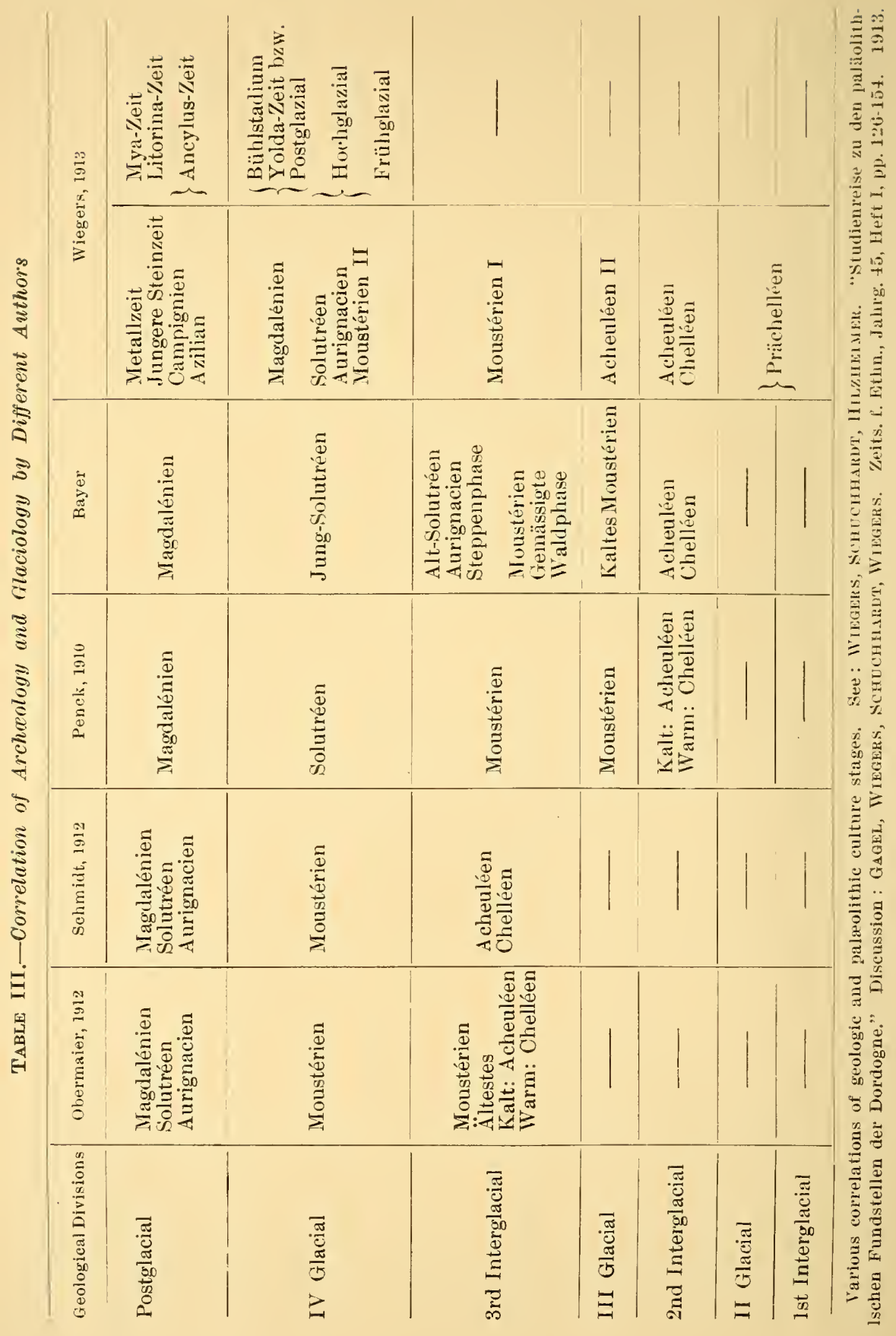


STRSIDENCE. submergence of the land and advance of the sea, land connections interrupted, advance of the glaciers, periods of deposition and filling of the valleys.

Thus Boule and Geikie consider the glacial stages as mainly periods of continental subsidence and filling of the valleys, the interglacial as times of elevation and erosion of valleys and terraces. Penck estimates the elevation of southern Europe at $100 \mathrm{~m}$. in the beginning of Pleistocene times: he speaks of the elevation of the Alps during the Second Interglacial Stage. Geikie describes the southern half of the North Sea as dry land during the First Interglacial Stage traversed by a northern extension of the River Rhine, while the approach of the Second Glacial Stage was heralded by a submergence of this area of the North Sea. Again (Geikie) during the Second Interglacial Stage the English Channel and probably a large part of the North Sea became dry land. Finally (Pohlig) during the Third Interglacial Stage there was a period of continental elevation and a dry, cold steppe climate in western Europe.

Consistent with this hypothesis is the deposition of loess during the Second and Third Interglacial Stages, also during the Postglacial Stage, because loess deposition is characteristic of dry and elevated continental climates with winds prevailing in one direction.

Final Subsidence.-Consistent with this hypothesis also is the fact that general and local subsidence in the northern hemisphere was the chief feature of closing Pleistocene times or the very cold Postglacial Stage; all the old continental connections which had been characteristic of the Tertiary were cut off; in the northwest the English Channel was formed, Great Britain became isolated from Europe, Ireland first lost its land connection with Wales and then with Scotland; to the eastward the Mediterranean Sea extended into the Egean region and cut off the old land connection between Greece and Asia, which had so long served to connect Greece with the mammalian life of southern Asia. During a period of extreme subsidence, the Black Sea, the Caspian, the Sea of Aral formed a large single sheet of water known as the Hyrcanian Sea. In southern Asia similar subsidence and separation phenomena were in progress; the islands of the East Indies, Sumatra and Java were cut nff from the Malay Peninsula. The separation of the Japan and Philippine archipelagos probably occurred in late Postglacial times. To the far northeast late in Pleistocene times Asia lost its connection with America, Bering Straits were reopened, and the so-called Nearctic region of North America was completely isolated from the Palæarctic region of Eurasia after a long period of community and free intermigration of Holaretic life. 
Final Elevation.- I'his extreme subsidence was followerl in late Postglacial times both in Europe and America by reëleration which gave the contiments their present contomrs and climates.

\section{ALTERNATIONS OF CLIMTATE AND FLORA}

Fluctuations of temperature and of moisture in Pleistocene times are indicated first by the advances and retreats of the ice caps, second by the presence of arctic or temperate Mollusca in the coast waters, third by the rariations in the flora in glacial and interglacial times, fourth by the alternate appearance of the northerly or southerly types of mammals and birds, fifth by the nature of the geologic depositions, sixth by the nature of the land Mollusca in the loess. Combining the evidence derived from these various sources the theoretic broad divisions of the climatic sequence are as follows: (1) the cold and moist phases connected with the successive glacial advances and retreats; (2) the warm to temperate climates of the First and Second Interglacial Stages and first half of the Third Interglacial; (3) the dry and cold climate of the second half of the Third Interglacial Stage and early Postglacial times; (4) the damp. and cool climate of late Postglacial times favorable to forests.

The theoretic alternating conditions of each complete glacial cycle are as follows : ${ }^{24}$
Subsidence: Glacial Maximum: Tundra flora and fauna
Glacial Retreat:
Cool and moist forest flora and fauna
Elevation :
Interglacial :
Dry conditions, flora and fauna. Steppe Glacial Advance: Cool forest fauna and flora
Subsidence: Glacial Maximum: Cold tundra flora and fauna

Low Glacial Stage Temperatures.-Low temperatures dnring the periods of glacial advance are attested both by the advent of northern Mollusca, marine and terrestrial, northern flora, and the repeated arrival in Furope of members of the cold fauna of the arctic tundras, including both the smaller and the larger mammals and the birds, as well as the cold fauna of the high, arid steppes of western Asia. Low temperatures are attested also in early Postglacial times during the great AurignacianMagdalenian art period by the heavy covering of hair indicated on all the animals depicted by the Upper Palæolithic artists. This hairy covering coincides exactly with that of the extreme northern tundra types of reindeer, woolly rhinoceros $(D$. antiquitatis) and woolly mammoth $(E$. primigenius) found imbedded in the ice or frozen soil.

24 Compare Wist. 
Moderate Estimates of Temperature.-That the advancing glaciers alone do not constitute proof of very low temperatures is observed in Alaska, where very heary snowfall or precipitation causes the accumulation of great glaciers, although the mean annual temperature of the glacier region is $40^{\circ}-45^{\circ} \mathrm{F} .\left(4.44^{\circ}-7.22^{\circ} \mathrm{C}\right.$. $)$ as compared with that of northern Germany, $45^{\circ}-50^{\circ} \mathrm{F}$. $\left(\% .22^{\circ}-10^{\circ}\right.$ C. $)$, $i$. e., from mouth of Rhine S. E. along source of northward flowing rivers, e.g., Elbe, Vistula, etc. Neumayr estimated that during the Ice Age there was a general lowering of temperature in Europe of not more than $6^{\circ} \mathrm{C}$. and held that even during the glacial advances a comparatively mild climate prevailed in Great Britain. Martins estimated that a lowering of temperature to the extent of $4^{\circ} \mathrm{C}$. would bring the glaciers of Chamonix down to the level of the plain of Geneva. Penck estimates that all other atmospheric conditions remaining the same as now a fall of temperature to the extent of $4^{\circ}$ to $5^{\circ}$ C. Would be sufficient to bring back the Glacial Epoch in Europe. Perhaps the strongest proof that Europe was not refrigerated during the first, second and third glacial advances is the survival of the African-Asiatic fauna throughout the whole period until the fourth glaciation, which was accompanied by widespread severity of climate.

Tharm and Temperate Interglacial Stages.-Similarly the early hypotheses of extremely warm or subtropical conditions, based chiefly upon the northerly distribution of hippopotami and rhinoceroses, animals which we now associate with tropical conditions, are not supported by the study of the interglacial flora. It is quite probable that both the hippopotami and rhinoceroses of the so-called "warm fauna" were covered with hair although by no means so thickly covered as the woolly rhinoceros and elephant of the arctic tundras. There is evidence that in the First Interglacial Stage southern England and France enjoyed somewhat warmer and moister conditions of climate than the present. The Second Interglacial Stage also, which is commonly distinguished as the "long warm" Interglacial Stage, was of somewhat higher temperature than the present. The general evidence is that both in Europe and North America, especially in the First and Second Interglacial intervals, the climate in the northern hemisphere was somewhat more equable and milder than at present, with a higher mean temperature, at certain intervals with greater precipitation of moisture, at other intervals much more cool and arid. There was perhaps more sunshine than now.

As a result of favorable interglacial conditions arboreal vegetation flourished to the far north along the Arctic ocean, and the present tundra regions of Siberia and British America then supported forests which 
liare long since been extirpated, the northern limit of similar living trees now lying far to the south.

- Aternations of Flora.-It is clear from these great sncessire fluctuations of temperature, moisture and aridity during Pleistocene tines that the flora cannot be treated as a unit nor as progressing in a single direction like the flora of preceding epochs: the flora as well as the fauna presented alternations of arctic, boreal and temperate species which migrated southward and northward following the advances or retreats of the glacial cap. Thus we may observe evidences of changes of climate and flora from forested conditions to steppe conditions and back to forested conditions. From the beginning of the Fourth Interglacial interval to the present time, the Alps region (Penck, Brïckner, 1909) bas apparently gone through a cycle of changes such as the following:

\section{VEGETATION}

Fourth, forest conditions

Thild, steppe conditions

Second, tundra contitions

First, forest conditions

\section{Climate}

Wester'n European, oceanic Western Asiatic, continental

\section{Northeastern-European. subarctic}

Western-European, oceanic

EPOCH

\section{Modern \\ Fourth Glacial and \\ Postglacial \\ Fourth Glacial}

Third Interglacial

The elephants (Hilzheimer, 1913) in the structure of their grinding teeth afford clear indications of the plant life, whether consisting mainly of grasses or forests, but not of elimate except in so far as regetation is dependent upon moisture. The advance and retreat of the ice is dependent both upon moisture and extreme cold and involves the frozen subsoil conditions of the tundras which are fatal to forests. Cases of alternation of conditions favorable to Elephas trogontherii, which is believed to be a grass-eating form, and of Elephas antiquus, which is believed to be a forest-living form, are observed in Taubach by Wüst. ${ }^{25}$ This author observes in the lower layers Elephas antiquus succeeded in the middle layers by $E$. trogontherii and then in the upper layers again by E. antiquus, and deduces from this succession a change of conditions from forest, to steppe, to forest.

\section{FAUNAL LIFE ZONES OF EUROPE}

In the whole history of the Mammalia in various parts of the world we know of no conditions so unusual and complex as those which prevailed in Europe in Pleistocene times. These conditions were the product of

§ WÜST, EWAID : "Die plistozänen Ablagerungen des Travertingebietes der Gegend von Weimar und ihre Fossilienbestände in ihrer Bedentung für die Beurtellung der Klimaschwankungen des Niszeitalters." Zeitschr. Naturw.. Bd. 82. pp. 161-252. Leipzig, 1911. 
cycles of environment and of life which have never prevailed before and will nerer recur even if the world were to enter a fifth glacial stage, for besides the extraordinary geographic and climatic changes which hare been outlined in the previous pages there was the prodigal profusion of life which survived from Pliocene times and has since become extinct.

The result of these complex conditions was the assemblage in Europe of animals indigenous to every continent on the globe except Soutl

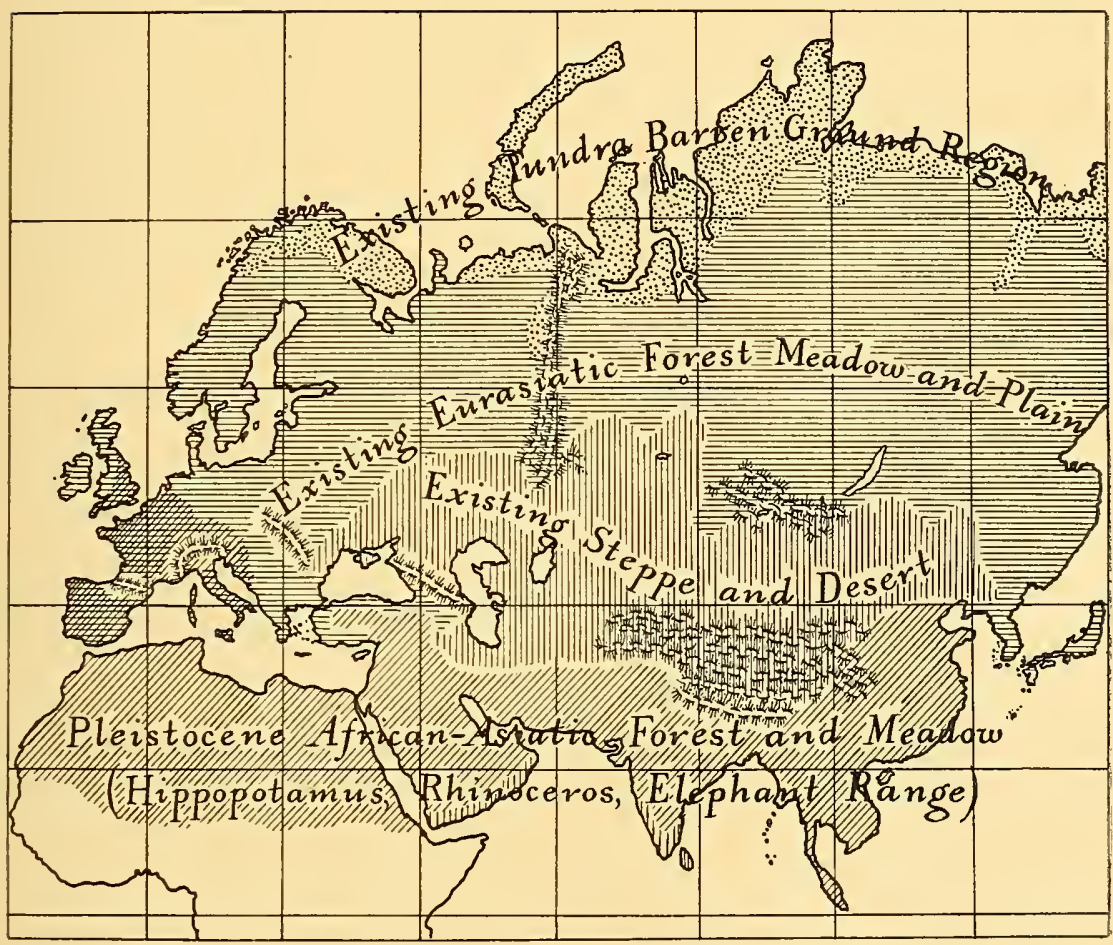

FIG. 6.-Five chief zö̈geographic regions of Europe, Asia and northern Africa from which the mammals migrated into western Europe during the Pleistocene

America and Australia, and adapted to every climatic life-zone from the warm and dry plains of southern Asia and northern Africa to the temperate forests and meadows of Eurasia, from the alpine heights of the Alps, Pyrenees and Altai Mountains to the high, dry steppes of central Asia with their alternating heat of summer and cold of winter, from the tundras or barren grounds of Scandinavia, northern Europe and Siberia to the mild climate of southern Europe. All these animals had been evolving during the Pliocene Epoch in these varions habitats and they 
also underwent a very considerable evolution during Pleistocene times in their respective habitats.

Owing to successive migrations and invasions into Europe of these exotic types of the north and south we should not expect to find a continuous phyletic evolution or transformation such as we have observed in the earlier epochs, excepting only that which occurred anong the Eurasiatic forest and meadow types which appear to have been native or indigenous in Europe from the earliest Pleistocene to prehistoric times. These Furasiatic forest and meadow mammals were continuous residents, retreating in the coldest periods to the shelters on the east and south. Cervus elaphus, for example, passed through several subspecific stages of evolution. The invading hordes from the tundras, the steppes, from northern Africa and from Asia represent branches which had their evolution elsewhere. This is true both of the mammals and of the races of men which had their genesis in the far east and southeast and arrived in Europe when it was a fertile peninsula, a region too small to be the seat of a continental evolution or adaptive radiation.

The five great regions which contributed to the European Pleistocene were as follows :

African and Aslatic, Plains and Forest Types

European and asiatic, Forest and Meadow Types

European and Asiatic, Arpine Types

Steppe Regions of Soutiern furasia and Eastern Siberia Arctic Tundra Regions of Northern Eurasia

Literature.-The African-Asiatic element in these Pleistocene faunas was the first to be recognized and commented upon by the early writers; it is commonly known as the "warm fauna." We owe especially to Nehring the discrimination between the tundra and the steppe faunas. Gaudry, Harlé, Noldrich, Studer and Boule have added to our knowledge of these faunæ. Other contributors are Pohlig, Soergel, Förster, Hilzheimer, Wüst and Dietrich. A strict systematic revision and introduction of the trinomial system is greatly needed. The most complete recent faunal lists of the late Pleistocene deposits in which traces of man are found are those of Koken and Schmidt (1912), who have also instituted the closest correlation between the migrations of the Mammalia and the successive stages of human culture.

African-1siatic Mammals. Warm Fauna.-These mammals include those which first appear in the Upper Pliocene and survive into Lower Pleistocene times: also those which first appear in the Second Interglacial Stage and constitute the so-called "warm fauna" which survived in Europe until the middle or close of the Third Interglacial Stage. The 
principal members of this list together with the probable continental centres of their origin are as follows:

Hacacus? sp. (Africa)

Elephas meridionalis (Asia)

Elephas antiquus (Asia-

Africa)

Dicerorhinus etruscus (Asia) Nishorn

" merchii (Asia)

Hippopotamus major (Asia)

Bos primigenius (Asia)

Bison priscus (Asia)

Equus stenonis

Machørodus latidens

Hyana speloxa (Asia-Africa) Höhlenhyäne

" striata (Asia-Africa)

Canis aureus (Africa)

Felis leo antiqua (Africa)

"pardus
Sudelefant

Altelefant

Mercksches Nashorn

Flusspierd

Urochs, Auerochs

Wisent, "Auerochs"

Schakal

Altlöwe

Leoparde
Macaque baboon

Southern mammoth

Straight-tusked elephant

Etruscan rhinoceros

Broad-nosed rhinoceros

Hippopotamus

Urus

Plimitive bison

Upper Pliocene horse

Sabre-toothed tiget.

Cave hyrena

Jackal

Lion

Leopard

The remains of these animals play a very important part both in the subdivision of the geologic horizons of Europe and in theories regarding the alternation of climates, as well as in the determination of the antiquity of man. They are found chiefly in the river sands, river deposits and "High Terraces" of the First and Second glaciations and "Low Terraces" of the Third Glacial and Interglacial Stages. Some survivors are found in the shelter and cavern deposits of the Third Interglacial Stage as objects of the chase. Only two of these animals, the urus and the bison, survive to become members of the Prehistoric Forest and Meadow Fauna of Europe. The lion also survived into Postglacial times but disappeared in Europe before the Prehistoric and Neolithic periods.

Although originally derived from southern Asia or from Africa, the woolly elephant (E. primigenius) and woolly rhinoceros (Diceros antiquitatis) are not to be placed with the African-Asiatic fauna because they appear in Europe only with the northern Glacial or Tundra Fauna and are invariably indicative of cold climatic periods.

Eurasiatic Forest and Meadow, Temperate Fauna.-These animals were resident in the forests and meadows of Europe during the entire Pleistocene Epoch and survived with a few exceptions into Postglacial and Prehistoric times. In fact, they are probably separable by differences of specific and subspecific value from their successors in prehistoric Europe, but many authors still embrace them within the existing specific terms. They are divided into Forest and Meadow types, the former with brachyodont teeth adapted to browsing habits and forest environment, the latter with elongate or hypsodont grinding teeth adapted to meadows and a diet 
of grasses. Some of them, like the beavers. are stream- and river-dwellers. Naturally there is not always a sharp line of division between the habitats of these Forest and Headow types: the Carmivora esecially wander after their prey from the forests into the meadows and along the stream borders. The cattle and bison frequent both the forests and meadows.

\section{Sus scrofa ferus \\ corvus claphus \\ Megaecros Germania \\ Cerius maral (Persia) \\ Capreolus eapreolus \\ Alces latifrons \\ Equus mosbachensis \\ Trogontherium euvieri \\ Castor fiber. \\ Sciurus vulgaris \\ Lepus cuniculus \\ Arvicola amphibius \\ " rattiecps \\ " agrestis \\ " glareolus}

Myoxus

Mus sylvaticus

Talpa europaa

Ursus deningeri

" aretos

“ spelaus

" arvernensis

Felis eatus

Lynehus lynx

Lynx cervaria.

Canis lupus

“ nesehcrsensis

“Suessi

Vulpes alopex

Meles taxus

Mustela vulgaris

" nuartes

Gulo luscus

Fotorius putorius

Lutra vulgaris

Bison priscus

Bos primigenius

Equus caballus (?sp.)

\section{Forest Mammals}

Wildschwein

Edelhirsch

Riesenhirsch

Reh

Elch

Biber

Eichhörnchen

Wildkaninchen

Wasserratte

Nordische Wublratte

Erdmaus

Rötelmaus

Deninger Bär

Brauner Bär

Iöhlenbär

gem. Wildkatze

gem. Luchs

Silberluchs

Wolf

gem. Fuchs

Dachs

gem. Marden

Edelmarder. Baummarder

Iltis

Fischotter

Meadow MammaLs

Wisent

roochs
Wild boar

lied deer, stag

Giant deer

Maral deer

Roedeer

Moose (broatd-faced)

Horse of Mosbach

Giant beaver

Beaver

squirrel

IVild rabbit

Dormouse

Forest mouse

Mole

Brown bear

Cave bear

$V$ al d'Arno bear

Wild eat

I.vnx

Furasiatic lyux

Wolf

\section{Common fox}

Badger

Marteu

I'ine marten

Wolverine

Polecat

otter

Bison

Urus 
Futorius ruluaris

Sorex vulgaris

cricetus rulgaris

Arricola terrestris

ariatis
Wriesel

Schermaus

serm. Feldnaus
Weisel

Shrew

Hamster

Meadow vole

Of these forest-living animals the giant deer (Megaceros), the cave bear (Crsus spelceus), the Maral deer (Cervus maral), the giant beaver (Trogontherium) and the early Pleistocene species of horse are among

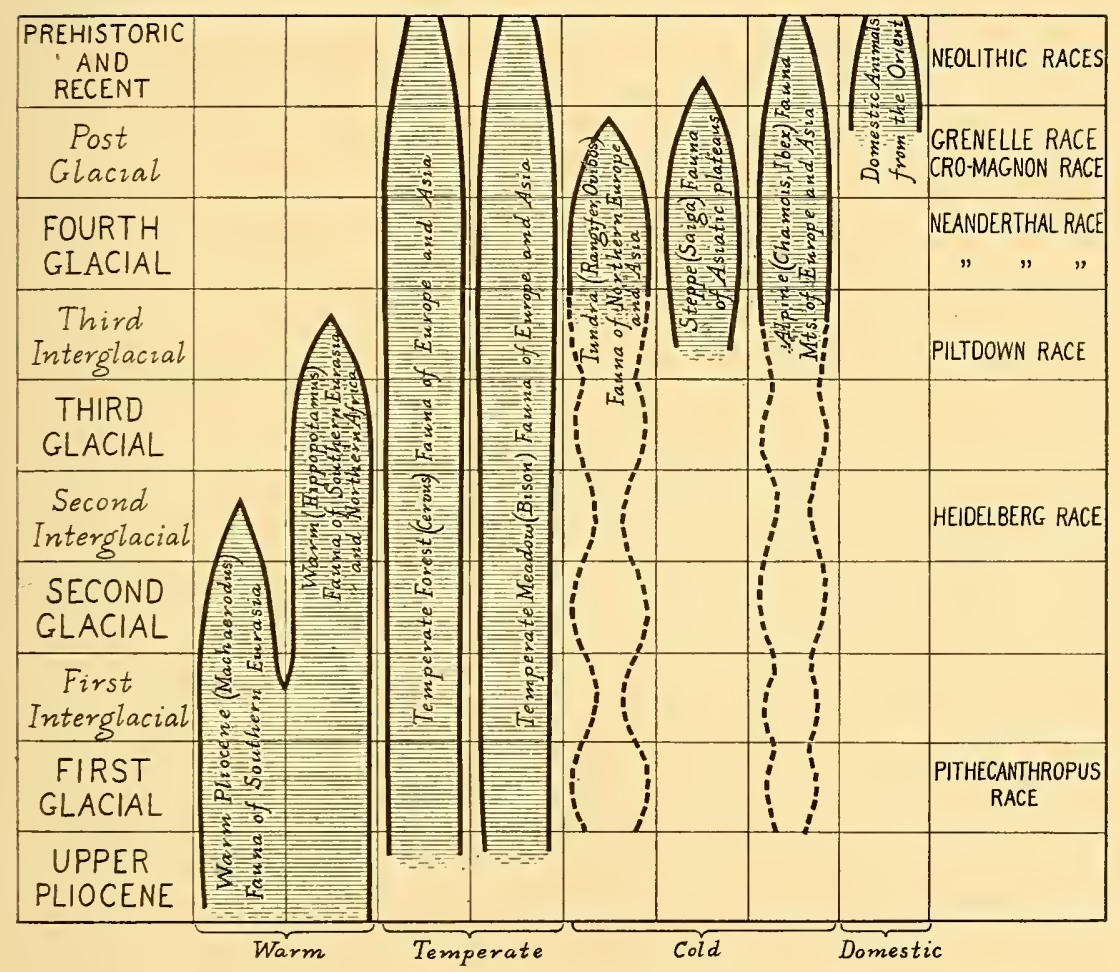

FIG. 7.-Introduction, succession and extinction of the faunde from the five chief zoiggeographic regions

African-Asiatic, Eurasiatic Forest and Meadow, Tundra, Steppe and Desert, Alpine.

the few forms which became extinct during the Glacial and Postglacial epochs. The great majority of these species survived with successive subspecific modifications.

It is a very remarkable fact that this true forest fauna of Europe is frequently found in the same deposits with the "warm fauna" of AfricanAsiatic origin. The bison and wild cattle appear in Europe from early 
Pleistoeene times, and in late Glacial and Postracial times they oceur as companions of the mammotli and the woolly rhinoceros.

Ilpine Mammuls, Cold Fauna.-During the serero onditions of late Pleistreene times the Alpine mammals were driven down into the plains or to the lower mountains and hills. and their remains occur principally during the last Glacial atrance. They are representerl buth in the drawings and in the soulptures of the men of the reindeer or eave period.

Ibex priscus

Rupicapra tianus

oris argaloides (Altai Mts.)

Arvicola nivalis

Lagopns alpinns

\section{Steinbock}

Gemse

Argalischaf

Schneemaus

Gebirgsschneehuhn
I'rimitive ibex

Cha mois

Argali sheep)

Alpine role

r'tarmigan

Steppe Fauna of Russia and Siberia.-Steppe conditions of climate were rendered possible in Europe by the elevation and extension of land much farther to the north and northwest than at present. At such periods all the tempering influences of the Atlantic Ocean were cut off from northern Europe and helped to gire central Europe a cold, dry continental climate farorable to dust storms.

Boule, Kobelt ${ }^{26}$ and Scharff ${ }^{27}$ have agreed in the opinion that the presence of steppe mammals affords inadequate proof of steppe conditions in the country. Other authors (Hilzheimer, 1913), however, strongly sustain the steppe-climate theory. The evidence for steppe conditions of climate has been strengthened in recent years by the discorery of three successive loess deposits.

The steppe regions of eastern Europe around the Caspian Sea and of central Asia still maintain this highly charaeteristic steppe fauna. The climate is usually one of hot, dry summers with high winds and prolonged cold winters with sweeping snow storms. The animals are consequently very hardy. The fauna inchudes the jerboa. suslik, bobac marmot, dwarf pica, hamsters, northern roles, corsac fox, the manul, or Pallas's cat (Felis manul). Corering the plains are the larger grazing animals such as the saiga antelopes, wild asses and wild horses (including the Equus przewalskii type). Another animal which probably belonged to the Steppe fauna is the Elasmotherium.

Elasmotherium sibiricm $m^{28}$

Equus pracualskii

" hemionus

Dschiggetai

Elasmothere

Mild Gobi horse

Dzegretai, wild ass, kiang

${ }^{2}$ KoвeLT, W. : Die Verbreitung der Tierwelt. Gemässigte Zone. Leipzig, 1902.

${ }^{27}$ ScharfF, R, F.: The History of the European Fauna. London, 1899.

28 Gaudre, Alrert and Bolle. Marcenhix: Jateriaux pour l'Histoire des Temps Quaternaires. Trois. Fasc. L’Elasmotherium. 4to. Libr. F. Savy, pp. 83-104, pll. xvixix. Paris, 1576. 
Naiga tartarica

- tactaga jaculus

Lagomus pusillus

s゙nermopluitus rufescens

Cricetus phous

Arctomys bobac

lyodes lagurus

Arvicola gregalis

Canis corsac

Putorius ciersmami.

Tetrao tetrix
Saiga antilope

Gr. Pferdespringer

Zwergpfeifhase

Rötliche Ziesel

KI. Steppenhamster

Sibirische Zweibelmaus

Pirkhuhn
Saica antelope

Jerboa

Dwarf pica, or tailless lare

Suslik, or pouched marmot

Steppe hamster

Bobac, or Polish marmot

Steppe lemming

Steppe vole

Corsac wolf

Steppe weasel

Ioorhen

Tundra or Barren Ground Fauna and Flora. ${ }^{29}$-Certain nembers of the Tundra Fauna adapted to the long cold winters and short summers of the lands bordering the Arctic Ocean appeared in Europe at the height of each of the great glacial adrances. The remains of these animals are al ways found within or close to the glacial drifts until the Fourth Glaciation when they spread all orer France, Germany and Austria. Thus the must-ox (Ovios moschatus). is recorded in the (?) First Glacial adrance of the Forest Bed of England. A tundra fauna including the reindeer (Rangifer tarandus) is recorded (Förster, 1913) with the Third Glacial adrance (Upper Mauer sands). An extensive Tundra Fauna also appears with the Third Glacial, or Riss Stage, in the "Mammutlehm" of Cannstatt (Koken, Schmidt, 1912, p. 2\%0): this is termed the "Older Primigenius" Fauna and occurs on the "high terraces" with the older Dilurium; it includes the woolly mammoth, the rhinoceros, the horse and the reindeer. The Tundra Fauna reappears toward the close of the Third Interglacial Stage (i. e. "Lower Rodent" layer), but the full series of species characteristic of the Tundra Fauna are not recorded in Europe until the Postglacial Stage (i. e. "T'pper Rodent" laver), when the entire Tundra list given below is discovered either mingled with the culture remains of the Neanderthal race of men in Mousterian times or is represented in the art of the Crô-Magnon men of the reindeer period. The full or typical Tundra list of the Fourth Glacial Epoch is as follows:

Elephas primigenins

Diceros antiquitatis

Rangifer trarandus

Oribos moschatus

Lepus variabilis

Myodes obensis
Mammut

Wollhariges Nashorn

Ren

Moschusochse

Schneehase

Oblemming
Mammoth

Woolly rhinoceros

Barren ground reindeer '

Musk-ox

Arctic hare

Obi lemming, or Siberian lemning

${ }^{29}$ Nehrisg, A.: ¿̈ber Tundren und Steppen der Jetzt- und Vorzeit, mit besonderer Berucksichtigung ihrer Fauna, pp. 81-166. Berlin, 1890. 


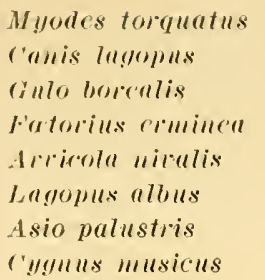

Myodes torquatus

r'anis lugupus

Cillo borecrlis

frestorius ermine'a

Arricolla niralis

Lagopus albus

('ylunus musicus

\author{
If:Ilshandlemmuniug \\ Eisfuchs \\ Vielfiass \\ (ir. Ilermelin
}

Moorschneehuhn

Sumpfeule

Ningsehwall bambled lemming

Aretic fox

Wohrerine (glutton)

Erinine

Arrice vole

I'tarmigall

Animals like the banded lemming adapted to extreme northerly conditions generally cling to these very obstinately and perish rather than conform to an altered enviromment (Nehring). 'This species dwells immediately to the north of the region of coniferous forests. among scattered shrubs of the common juniper (Juniperus communis), the dwarf birch (Betula nana), the polar willow (Salix polaris) and the mountain dryas (Dryas octopetala). Thus we may be confident that the lemmings discorered in Pleistocene times in England, France, Belgium and a large part of Germany are proof of climatic conditions similar to those of the present circumpolar region. We must conclude that the borders of the ice caps rrere surrounded by tundra or barren ground conditions at sereral Pleistocene stages. The lemmings probably dwelt in the immediate neighborhood of the glaciers. The existing tundras are characterized by frozen subsoil and the absence of trees or shrubs except along the river borders.

The reason for associating the woolly mammoth with this fauna is that the mammoth as depicted by the men of the Postglacial Stage agrees precisely in its form, its proportions, and its hairy covering with the mammoths which hare been discovered in the frozen subsoil of northern Siberia and are washing out in large numbers along the northern Siberian and American coast at Eschholtz Bay and elsewhere. At Thiede near Braunschweig, a classic locality, the lemming remains are associated with those of the arctic fox, arctic hare, reindeer, musk-ox and mammoth. Thus the comparison of certain regions of Pleistocene France and Germany with arctic Eurasia and the barren grounds of northern Asia and North America is based on the strongest evidence.

\section{MIGRATION THEORY OF FLORAS AND FAUNAS}

The principal contributors to the theory of northward and southward migrations and to the succession of faunas and floras are Nehring (18801896), Woldrich (1882-1896) and Penck (1896-1909). Such alternation is held by Penck to be demonstrated in Switzerland, where during the Third or Riss glaciation the woolly mammoth and woolly rhinoceros 


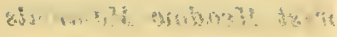

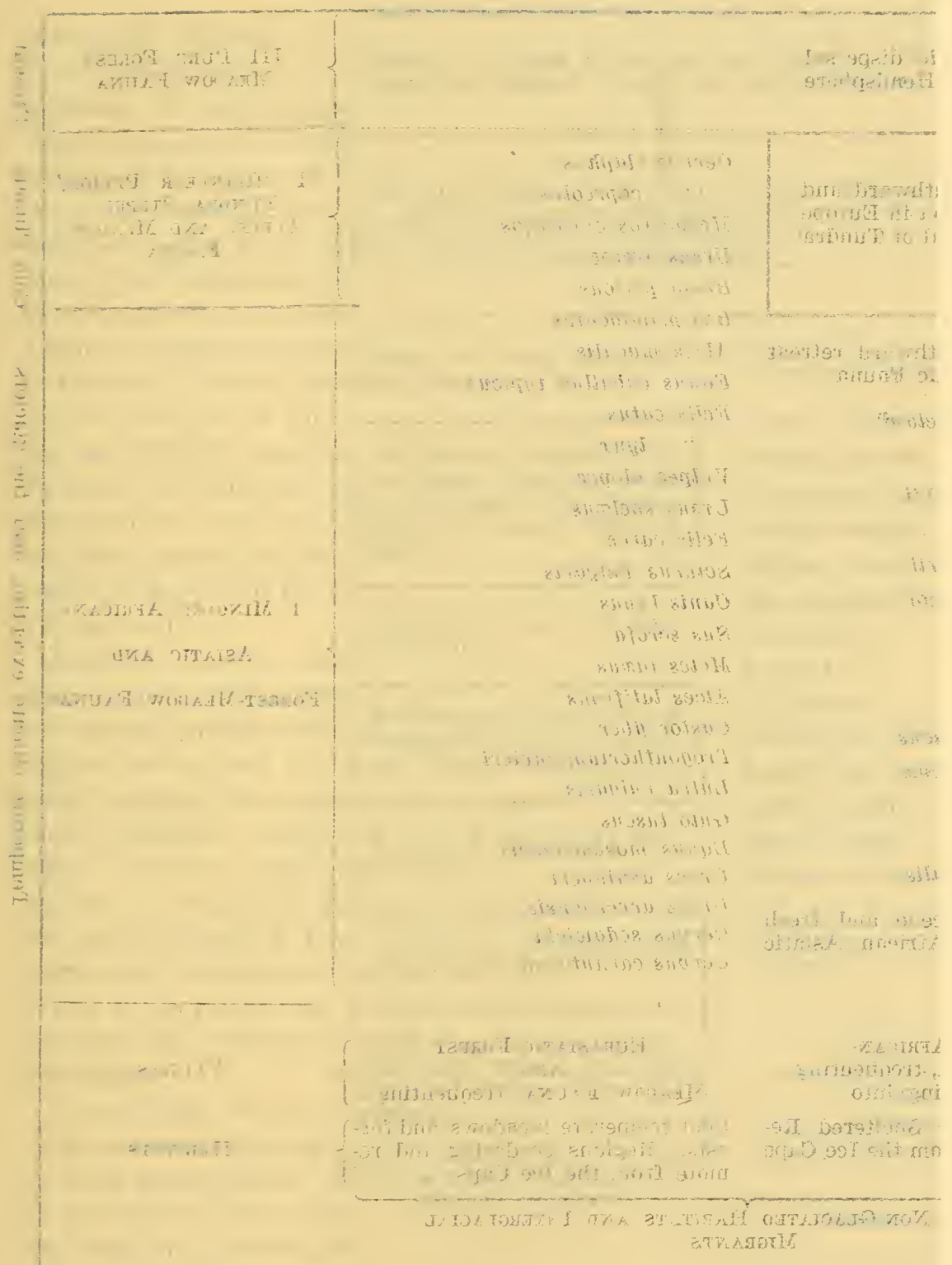

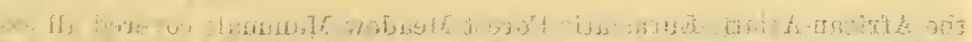

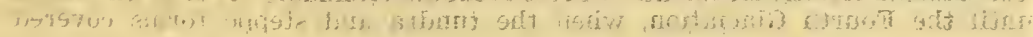




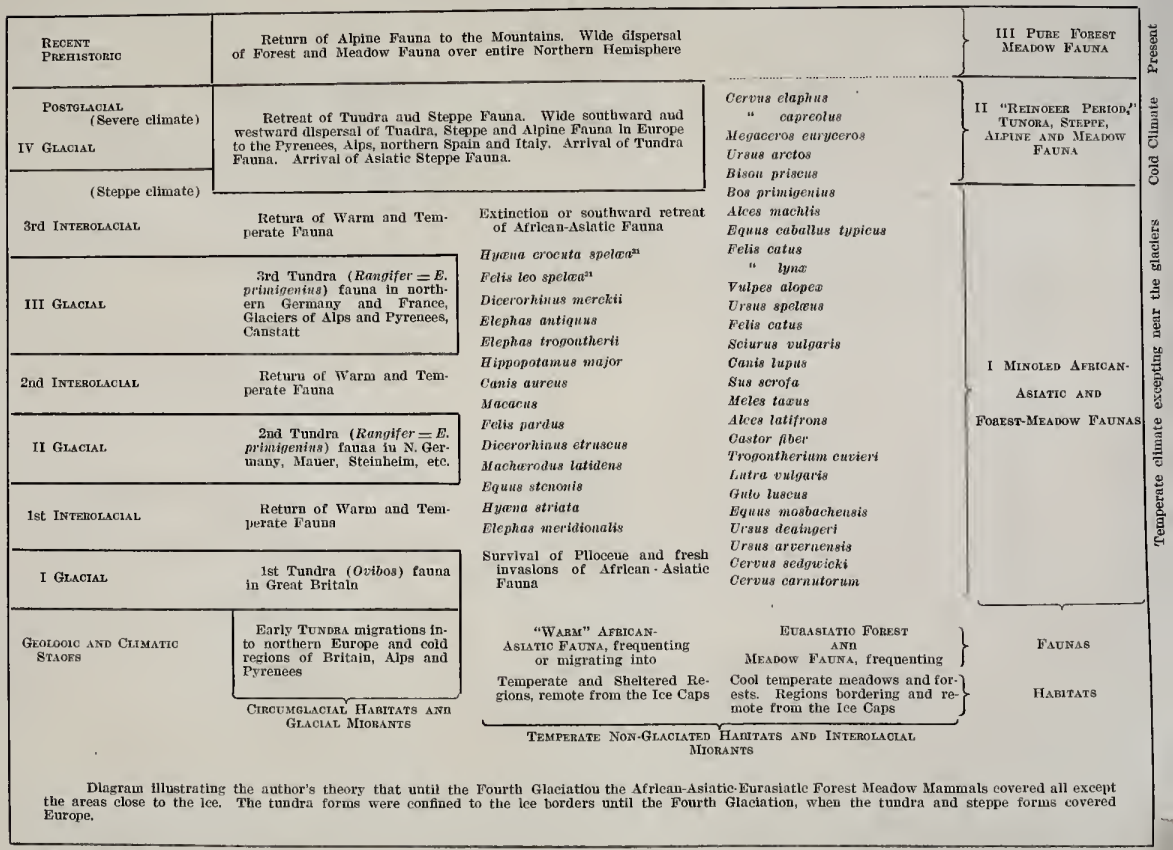

"Hyone spelaa and Felis leo spelac, the sole survivors of the African Asiatic Fana in the Cold Reladeer period of IV Giacial and Postgiacial timea, 



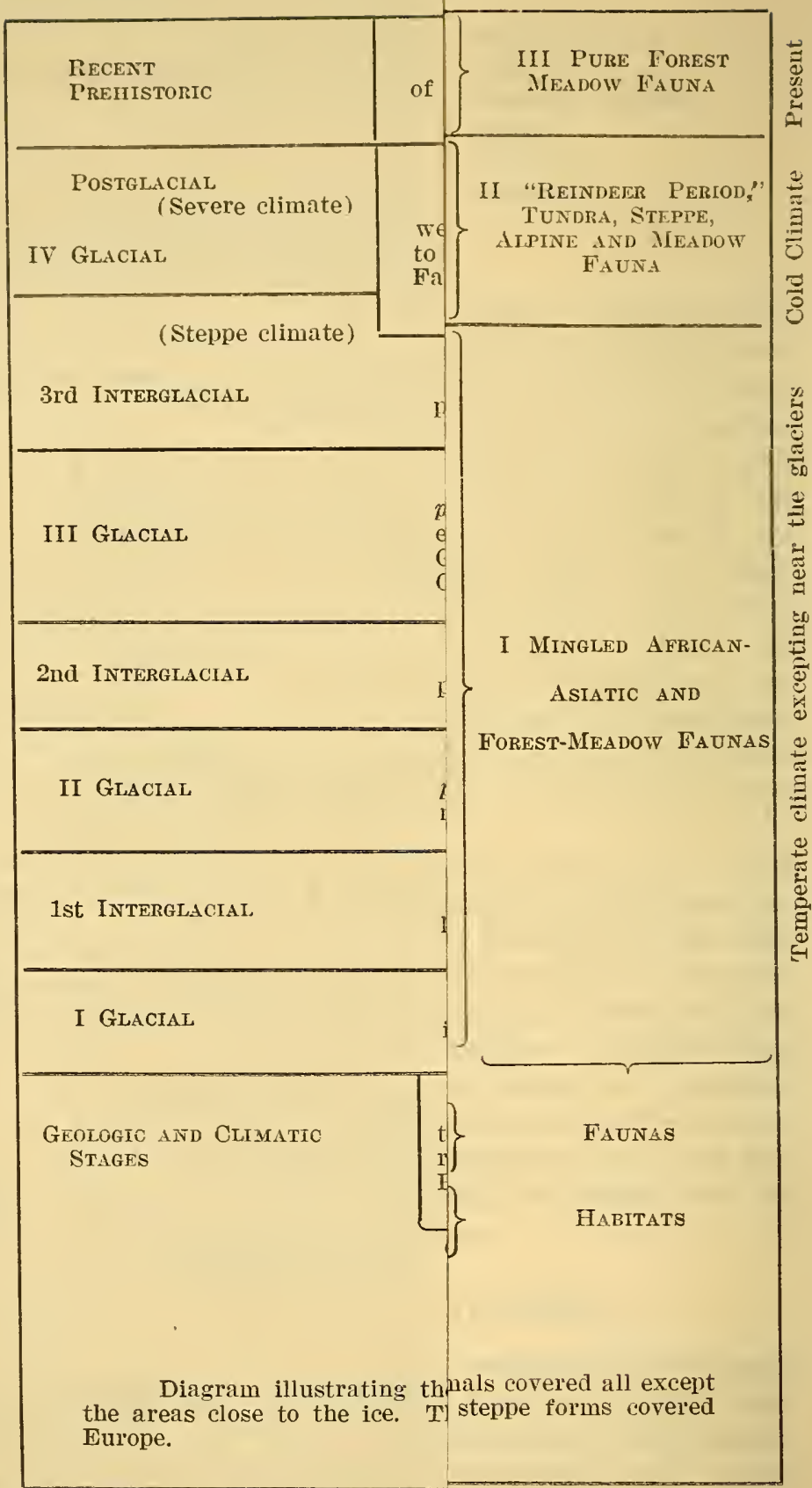

${ }^{81}$ Hyana spelaa and Felis leo spelaea, 
first appear in Europe, only to be succeeded in the Third Interglacial or Riss-II iirm Stage by the reappearance of the warm African-Asiatic fauna, including the straight-tusked elephant (E. antiquus) and the broadnosed rhinoceros (D. merchii). Theoretically this warm fauna was again dricen out during the Fourth or Wiirm glaciation by the reappearance of the woolly elephant and the woolly rhinoceros. Penck ${ }^{30}$ observes, as noted above, that we cannot hope to trace a continuous evolution of forms during the Pleistocene because we are not dealing with the development of one successive series in one locality but with the cycical evolution of a number of different faunas compelled to migrate because of alternations of temperature and of flora, the mammals disappearing ant returning at intervals too brief to allow of any marked erolutionary changes. Herein lies our difficulty when we attempt to distinguish between the Tundra Fauna of the Third and Fourth glaciations and the Forest Fauna of the corresponding interglacial stages, because the faunas return not only with the same generic but with the same specific types, as is especially illustrated in the case of the mamnoth (E. primigenius) and the giant deer (Hegaceros).

Resident Theory.-Another theory is presented in the accompanying table, namely, that during the First, Second and Third Glacial Stages the climatic conditions of Europe were temperate except in the immediate regions surrounding the glaciers. It was these glacial border regions which attrasted the tundra fauna of the north, the reindeer and the woolly mammoth. Supporting this theory is the fact that the tundra and steppe fossils are found only in proximity to the ice caps and glaciated regions. It is not until the Fourth Glacial Stage and the Postglacial that the general climate of Europe was so severe as to cause the gradual emigration and extinction of the African-Asiatic fauna. At this stage remains of the tundra and steppe mammals occur in all parts of Europe, including the Pyrenees and Cantabrian Alps, but only partly extending into Spain.

Latitude and Altitude.-In considering the distribution and migration of the mammals throughout the Glacial Epoch, we must constantly keep in mind the differences of latitude and of climate which prevailed then as now between Italy, Spain, southern and northern France. Germany and Belgium: also the differences of altitude as between the lowlands of the rivers Rhone and Dordogne and the highlands of the Alps and other mountains. Italy had a more moderate climate than central Europe: the reindeer seems never to have found its way there, yet a lowering of tem-

\footnotetext{
35) PExck, A.: "Die alpinen Eiszeitbildungen und der prähistorische Mensch." Arch.
} Anthropol., X. S., Vol. I. No. S. pp. Theo. 1:04t. 
perature in Italy is indicated by the fact that the Alpine mammals such as the mamot (Arclomys marmolla). chanois (Rupicapra) and stembok (Ibere) came down to the plains." The "old elephant" (E. antipuus) fama appeared in laty earlier tlan in northern Europe. Similarly the hippopotamus survived in laly longer than in France and Germany, so it is not surprising to find its remains associated with those of the blomelnosed rhinoceros (D. merckii) in a cave near Mentone on the French Riviera which belongs just prior to the Postglacial period of Aurignacian conlture corresponding with the period immediately succeeding the Fourth glaciation. ${ }^{33}$ Italy was a forested country at the time that central Furope was tundra-like or steppe-like.

Culture Stages.-Under all these varying conditions of climate human evolution progressively adrances, and where the "species" of lower manmals fail us the successive human culture stages enable us to sharply distinguish the intervals of time.

Repetition of Loess Depositions.-According to Wiust ${ }^{34}$ (p. 229) the First (I) and Second (II) Glacial and the First Interglacial Stages (1st) are represented in the single northern (Saxonian + Scanian) glaciation of Thuringia. The successive depositions of loess therefore occurred as follows :

Postglacial stage, the youngest loess. Postglacial terraces.

IV (WÜRM) GLACIAL STAGL, equivalent to northern glaciation MIT.

3 id (Riss-Wïrm) Interglacial stage, rounger loess. The lower terrares. of the 2nd (i. e.. 3rd Interglacial).

III (RISS) GLACIAI STAGE, equivalent to glaciation II of the north.

2nd (Mindel-Riss) Interglacial stage, older loess. The higher and middle terraces of the First (i.e., 2nd) Interglacial.

I-II (GÜNZ-IIINDEL) GLACTITION, equiralent to glaciation I of Thuringia.

\section{First Glacial Stagli-güx\%, Scaxian, Nebraskan}

The First Glacial Stage is believed to have been nearly contemporaneous in Europe and North America. It is estimated (Penck) that the various ice caps reached the climax of their advance 520,000 years ago and that the snow line in the Alpine Region descended 1,200m. lower than the present snow line. In the north of Germany and in Sweren

${ }^{32}$ Issex. A. : "Liguria geologie e preistorica." Ref, by Boule in L'Anthrol., pp. 602604. 1893 .

${ }^{33}$ Pexck, A. : "Die alpinen Eiszeitbildungen der prähistorische Mensch." Arch. Anthropol., N. S.. Vol. I. No. S, pp. 7s-90. 1904.

${ }^{34}$ Wíst, WwaLD: "Die plistozanen Ablagerungen des Trarertingebietes der Gegend von Weimar und ihre Fossilienbestände in ihrer Bedeutung fiir die Berrteilung der Klimaschwankungen des Eiszeitalters." Zeitschr. f. Naturwissensch., Band 82, Heft 3-5, pp. 161-252. Leipzig. 1910. Published Mar., 1911. 
the deposits of this glacial advance are known as the old "Diluvium" or the "Oldest Drift;" the advance is termed the Scanian by Geikie. In the Alpine Region it has been termed the Günz by Penck and Brückner, and the drift deposits have a general thickness of $30 \mathrm{~m}$. At about the same time a great ice cap was formed in British North America west of Hudson Bay from a centre known as Keewatin which sent its ice sheets into Iowa and Nebraska. The resulting Nebraskan deposits, consisting largely of compact boulder clays, are often thickly set with woody ma-

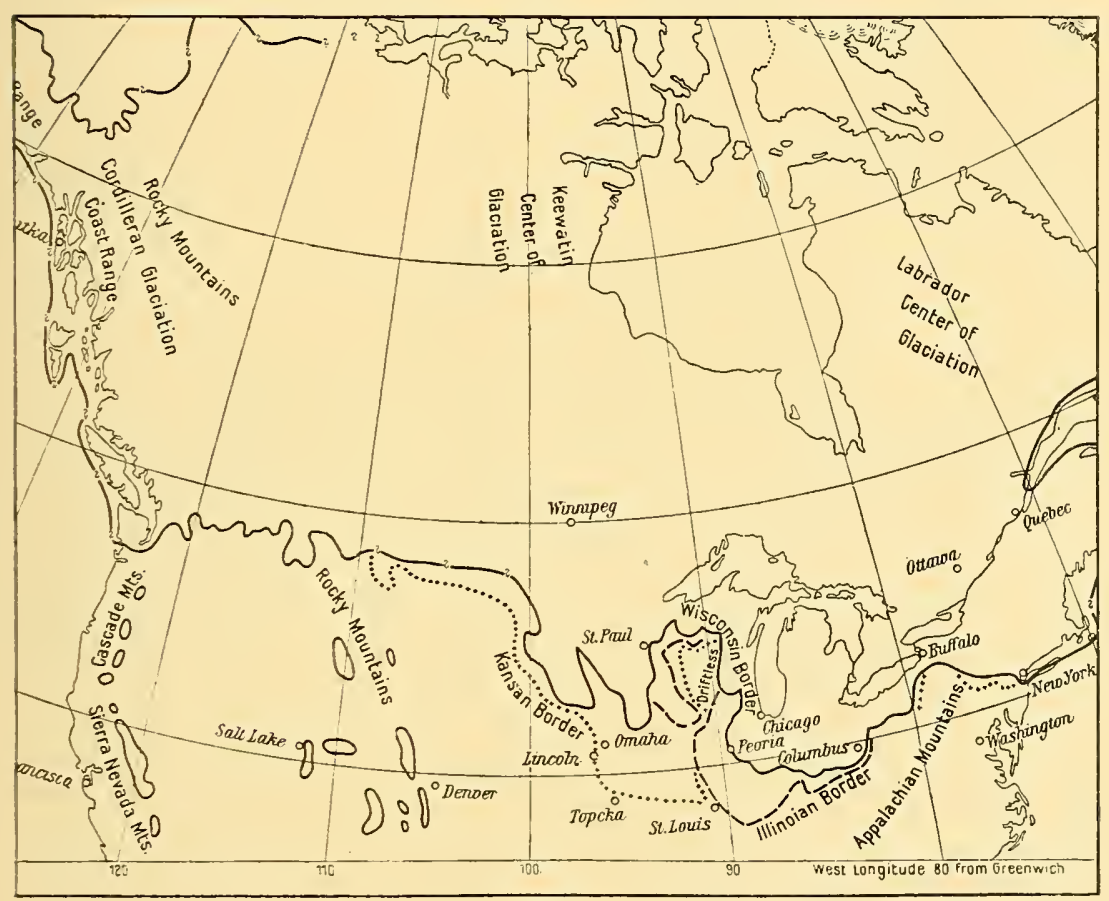

Fig. 8.- Chief centers of North American glaciation

Keewatin, Labradorean, Cordilleran. After Leverett.

terial gathered from forests of spruce and other coniferous species that indicate the development of a cool temperate flora in advance of the glaciation. ${ }^{35}$

It does not appear that a glacial cap of any considerable extent was formed in Great Britain; but Geikie ${ }^{36}$ shows that along the British coast

35 The above correlation is presented chiefly on the authority of Penck and Levereft (op. cit., 1910).

${ }^{36}$ Geikie, Jayes: The Great Ice Age, 2nd Ed. London, 1877. 
in Upper Pliocene times cold conditions began to manifest themselves in the Pliocene Red Crag and continued with increasing intensity during the deposition of the post-Pliocene Chillesford and Weybourn Crags, which mark a culminating time in which the sea abounded in Arctic molluses, and this may represent the first glacial stage in Britain.

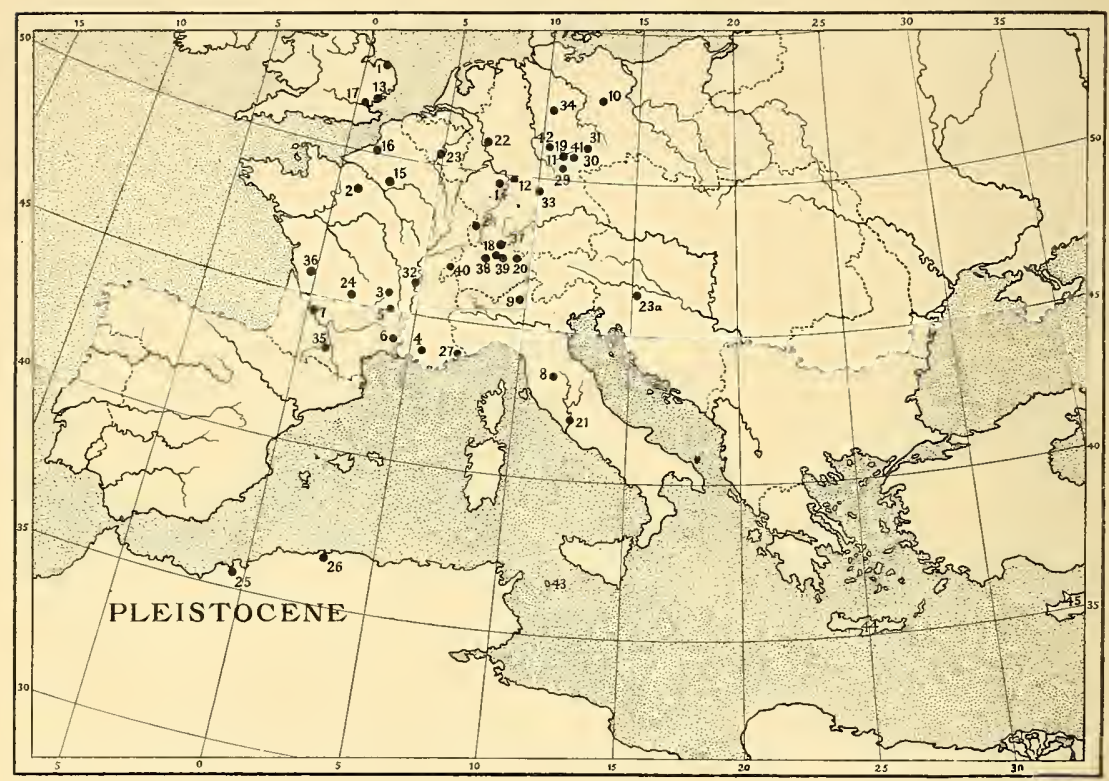

FrG. 9,-Principal mammal deposits and culture stations of the Pleistocene of Europe

1. Forest Bed of Cromer (Norfolk). Sables de 2. St. Prest near Chartres (Eure-etLoire). 3. Malbattu (Puy-de-Dôme). 4. Peyrolles (Bouches-du-Rhône). 5. Solnilac near Puy. Clay deposits of 6. Durfort (Gard). 7. Cajarc (Lot-et-Garonne). 8. Val d'Arno (Tuscany). 9. Leffe neal Bergamo (Lombardy). 10. Rixdorf near l'otsdam (Brandenburg). Gravels of 11. Süssenborn near Weimar, Sands of 12. Mosbach in northern Baden. Fresh-water deposits of 13. Clacton (Essex). Sands of Maur near 14. Heidelberg (western Germany). 15. Chelles on the Marne, near Paris. 16. St. Acheul (Somme), 17. Ilford and Grays Thurrock (Essex), Lignites of 18. Dürnten and of Utznach, near Zürich. 19. Taubach near Weimar. 20. Wildkirchli cave on Mont Silntis (eastern Switzerland). Tuffs of 21. the Tiber Valley, near Rome. Caves of 22. Neandertal, near Diisseldorf (western Germany), 23. Spy, near Amur (Belgium), $23 a$. Krapina (Croatia), 24. Chapelle-aux-Saints (Corrèze). Caves and alluvial deposits of 25. Ternifine (or Palikao) near Oran (Algeria), 26. Pointe Pescade, near Algiers (Algeria). 27. Prince's Cave (Monaco). Sandy clays of 28. Vöklinshofen (Alsace). 29. Saalfeld (Saxe-Meiningen). Travertines, etc., of 30. Gera. Jena (Saxe-Weimar). 31. Leipzig (Saxony). 32. Solutré, north of Lyons. Loess of 33. Nïrzburg (Bavaria). 34. Thiede near Braunschweig (Prussia). Cave of 35. Montmaurin (Haute-Garonne). 36. Châteauneuf-sur-Charente (Charente). Caves of 37. Schweizersbild near Schaffhausen, and Kesslerloch near Thayngen (northern Switzerland). Remains of lake dwellings at 38. Wauwyl (Lucerne), 39. Robenhausen, south of Lake Pfäfikon, 40. Concise on Lake Neuchâtel (Switzerland). Peatbogs of 41 . Hassleben. near Weimar. Travertines of 12 . Langensalza (Erfurt) in central Germany. Caves of the 43. Island of Malta, 44. Island of Crete, 45. Island of Cyprus. 
First Ixterglaclal S'tage-Norfolkian, Aftontax, Günz-Mindel

Inmediately after the deposition of the Weybourn Crag in Essex there is eridence of a climatic reaction because the overlying deposits, both estuarine and fluviatile. of the so-called Forest Bed of Cromer (Norfolk) contain a flora and mammalian fauna of warm temperate type which contrast strongly with the assemblage of the northern and Arctic molluses in the subjacent deposits of the Red, Chillesford and Weybourn Crags. From this classic locality of Norfolk the First Interglacial Stage - has derived its designation Torfolkian. It is also known as the Cromerian.

The first cold period or glacial advance was succeeded both in Europe and America by climatic conditions milder than the present. In the Alpine region Penck and Brückner have found evidences of a long Giunz-Mindel interval of time, estimated relatively at 100,000 rears, which separates the climax of the first or Günz glaciation from the second or Mindel. but they believe that this First Interglacial Stage was much shorter than the Second Interglacial. Owing to the warmth of the climate the snow line of the Alps is believed to have risen $300 \mathrm{~m}$. higher than at the present time. The deposits of this stage include the Paludinembank of northern Germany; these fresh-water deposits near Berlin are of true interglacial time, since they lie between the deposits of two Glacial adrances. The most abundant species, Paludina alluviana, has its present habitat far to the south on the borders of the Black Sea. In general the other fresh-water and land molluses belong to modern species common to the same region to-day, indicating that climatic conditions were not greatly dissimilar from the present. The plant remains include the mosses and conifers, also indicating a climate similar to the present, but they probably do not afford evidence of the higher ranges of temperature which may have occurred at other times and places during this First Interglacial Perior. In America the deposits of this First Interglacial Stage, known as the Aftonian, are widely distributed and vield a rich mammalian as well as a land molluscan fauna and abundant plant remains which generally indicate a temperate to warm climate.

\section{HUIID FOREST CONDTTIONS}

A striking characteristic of this interglacial stage is the evidence of prolonger humid conditions of climate and abundant forestation favorable to forest-living mammals. There is no evidence either in the north r.f Germany or in the northern Lnited states of loess deposits such as occur during the Second and Third Interglacial Stages and are believed to be due to recurrent arid conditions and dust storms. 


\section{FLORA OF THE FIRST INTERGLACIAL PERIOU}

In the "Forest Bed of Cromer" on the eastern coast of England the arrival of Abies is significant because although known in Miocene times in the Arctic region of Grinnell Land this is the first appearance of the fir tree in central Europe; the fir is also found in the interglacial lignites of Switzerland and has since constituted an important member of the European forests. Including the fir, all the trees composing the forests in the region of Norfolk belong to living species, such as the maple, elm, birch, willow, alder, oak, beech, pine, spruce, still indigenous to this region, latitude $52^{\circ} 40^{\prime} \mathrm{N}$. A notable fact in examining this flora of the Norfolk and Suffolk coasts of England is its correspondence with the modern flora in spite of the immense period of time that has elapsed and the great changes in climate during which all these plants were driven to the south and again permitted to return. "However," continues Reid, "though very similar, we find in the fossil flora several exotic species which give it a slightly different character and we notice also the absence of several modern forms." From this tree flora Reid concludes that the climate of southeastern England was nearly the same as at present, but slightly warmer.

The flora of Durfort (Gard) in southern France is associated with remains of the southern elephant ( $E$. meridionalis), the etruscan rhinoceros (D. etruscus) and the Pliocene horse (Equus stenonis). ${ }^{38}$ It includes numerous plants of species now represented in the Caucasus, Persia, southern Italy, Portugal and Japan. Again. in the interglacial forests of Moret (Seine valley) we find the fig (Ficus) and the Judas tree (Cercis), indicating a mild temperature. The tree flora of France like that of Torfolk thus indicates somewhat warmer conditions of temperature than prerail at the present time, a temperature of $4^{\circ}$ of latitude to the south.

\section{MAMMALS OF TIIE FIRST INTERGLACIAL STAGE}

For our knowledge of the mammalian life of the Forest Bed of Norfolk and contemporaneous deposits of France we are indebted principally to Dawkins (1880, 1883), Newton (1880), Gaudry (1893). Bonle (1902), and Pohlig (190\%). Dawkins many years ago (1883, p. 589) estimated the ratio of living. extinct and newly arriving mammals in the Forest Ber as follows:

\footnotetext{
37 Reid, C., and Reid, E. M. : "The Pre-Glacial Flora of Britain." Jour. Linn. Soc., Botany. Vol. xxxriii, pp. 206-227. Jan., 1\%os.

${ }^{38}$ Garnix. A. : L:Eléphant de Durfort. Paris, 1893.
} 
Survivals from the Pliocene.............11 species

Newcomers. forms now extinct........... "

Newcomers. forms still liviug............

The specific determinations of many of these animals are based upon very incomplete materials and await careful revision; and upon this closer study will depend also the correlations between the various First Interglacial faunæ of Great Britain and the continent. From our present knowledge the following faunistic correlation may be made:

Northern Life. Forest Bed of Cromer, Norfolk, England (Fig. 9, 1), typical of the northern life.

Sables de St. Prest (Eure-et-Loire), France, (2) typical of the central life of France.

Malbattu (Puy-de-Dôme), France, (3) typical of the central life of France.

southern I.ife. Peyrolles (Bouches-du-Rhône), France, (4) typical of the southeru life of France.

Solilhac, near Puy, southern France, (5) typical of the southern life.

Durfort (Gard), southern France, (6) typical of the southern life.

Cajare, Lot-et-Garonne, ( 7 ) typical of the southern life.

Val d'Arno (upper, or Pleistocene deposits), northern Italy, (s) typical of the southern life of Europe.

Extinctions.-The survival of a number of Pliocene mammals into this period has led certain palæontologists, such as Boule, to place the First Interglacial fauna and the Glacial stage which preceded it in the Pliocene rather than in the Pleistocene Epoch. The true Upper Pliocene fauna, howerer, is characterized by a number of distinctively Pliocene mammals, especially the primates, mastodons, antelopes, gazelles and tapirs. Tone of these animals have been found in the Pleistocene of Europe; all had become extinct.

Survirals. - This First Interglacial fauna does include, however, a number of survivals from the Pliocene, such as the sabre-tooth eats (Machcorodus), the polycladine deer ( $C$. sedgwicki), the more primitive dicerorhine rhinoceros with brachyodont teeth ( $D$. etruscus), the primitire Upper Pliocene horse (Equus stenonis), the southern elephants ( $E$. meridionalis). the hippopotami, the roedeer (Capreolus capreolus), the giant bearer (Trogontherium), the Auvergne bear (Ursus arvernensis), the wild cattle (Leptobos).

It is noteworthy that Pohlig considers the E. mevidionalis of this stage to be of more recent type than the true Pliocene type of Italy described by Testi; hence he terms it $E$. (meritionalis) trogontherii. It is also 
noteworthy that the polycladine deer (Cerus sedgwirki) do not reappear in any of the subsequent Pleistocene formations of Europe.

Arivals.-Among the new arrivals in the Forest Berl of Sorfolk are the earliest members of the giant deer race (Megaceros) which continues into Middle Pleistocene times in Europe. We also note in the Forest Bed the presence of a form (Caprovis) intermediate between the goat and the sheep, as the name indicates, and most closely resembling the moufflon of Sardinia. Among the rodents the large beaver Trogonthe-

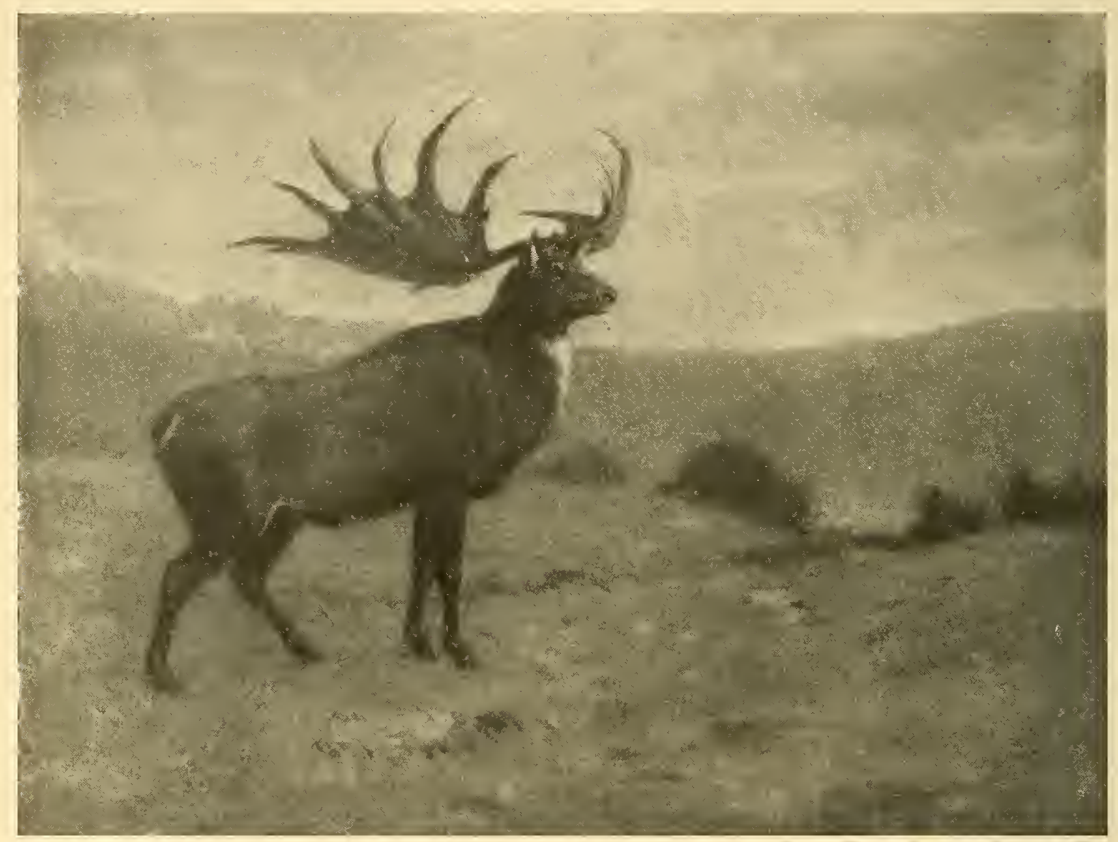

Fig. 10.-Giant deer. Megaceros, of the British Pleistocene

From a skeleton found in the Irish peat bogs. After original by Charles $\mathrm{R}$. Knight in the American Museum of Natural History.

rium cuvieri succeeds the smaller ancestral species (T. minus) first observed in the Pliocene of the Red Crag. The giant hippopotamus ( $H$. major) is certainly recorded in this region of Great Britain as well as to the south in Italy.

Among the proofs of a northerly climate is the first occurrence of the musk-ox (Oribus), which is attributed by Dawkins ${ }^{39}$ to the Forest Bed deposits.

${ }^{39}$ DAwKins, W. Boyd: "On the Alleged Existence of Oribos moschatus in the Forestbed. and on its Range in space and Time." Quart. Jour. Geol. Soc. London, Vol. 39, pl. $576-579.1883$. 
Anong the animals attributed by Dawkins to the Forest Bed fauna which Newton ${ }^{40}$ considers of doubtful reference are the hyæna, the true cattle (Bos primigenius), the red deer (Cervus elaphus), the moose (Alces latifrons) and the giant deer (Megaceros). These animals are, however, certainly recorded in France (Cajarc) with the exception of the moose (Alces).

The presence of deer (Cervidæ) in great numbers and representing many different phyla is one of the most distinctive features of First Interglacial times. There existed numerous and varied forms of deer life both in Great Britain and southern and western Europe, attesting the presence of forests. They belong to several, probably to as many as five distinct phyla. Among these the polycladine, or "many-branched" deer so distinctive of the Upper Pliocene of the Tal d'Arno now make their last appearance in Europe as Sedgwick's deer (C. sedgwicki) of the Forest Bed. with remarkably complex antlers closer to the $C$. dicranius of the Tal d'Arno. A second Pliocene European phylum is that of the roedeer (C. capreolus). A third phylum, numerous and highly diversified, is that of the giant deer (Megaceros) which is represented by a variety of species (M. verticornis, M. fitchii, M. dawkinsi). There is some doubt whether the true "deer of the Carnutes" (C. carnutorum) occurs here. As above noted Newton is uncertain whether the stag ( $C$. elaphus) has been truly recorded in the Forest Bed. Neither the true fallow deer (Cerrus dama) nor the reindeer (Rangifer tarandus) has been recorded there.

This Forest Bed fauna as a whole is an outlier of the Asiatic-African group with a strong northerly Eurasiatic forest element intermingled. We observe that browsing, forest-living and fluviatile types predominate. Among the forest-frequenting carnivores are the wolverine (Guto), the otter (Lutra), two kinds of bear (Ursus), the wolf (Canis), the fox (Tulpes), the marten (Mustela) and a true feline (Felis) in addition to numerous representatives of the sabre-tooth tigers (Macharodus). All the above are true Eurasiatic forest types from north-temperate latitudes. Among the forest-living browsers also is a large boar related to Sus scrofa, the primitive browsing rhinoceros (Dicerorhinus etruscus) with short-crowned teeth, while in the rivers disported the giant hippopotamus ( $H$. major). Among the grazing and meadow-living forms Bos or Leptobos is represented in the Forest Bed. There are also two species of horses including a lighter form resembling the $E$. stenonis

40) Newtos, F. T. : "Notes on the Vertebrata of the Pre-Glacial Forest Bed Series of the East of England." Creol. Mag., Vol, vii, I't. I, Carnivora, pp. 152-155, Pt. II, Carnivora, pp. 424-427, I’t. III, Ungulata, pp. 447-452. Jl. xv. 1880. 
corchi of the Val d'Arno, and a heavier type of horse, probably forestliving.

Cool estuarine eonditions are represented by the presence of the walrus (Trichecodon), the seal (Phoca) and the cormorant (Phalacrocoror).

The ehief members of the mammalian assemblage of the First Interglacial Stage in Britain and France are as follows:

Southern elephants

E. meridionalis (troyontherii)

Dicerorhine rhinoceroses

I). etrusens

Primitive horses

L. stenonis, $E$. eaballus fossilis ?

Hippopotami

H. major

Polycladine deer

C. sedguichi

Roe deer

C. capreolus

Giant deer, Megaceros

11. dawkinsi, M. verticornis

Primitive cattle

Bos primigenius

Giant beaver

Trugontherium euvieri

Sabre tooth cats

Macharodus ? eultridens

Wolverines or gluttons (in Great

Britain)

Gulo 7uscus

Bear of the Ursus aretos type

Otters and martens

Wolves and foxes

Walrus (in Great Britain)

Trichecorlon huxleyi

(In Italy only)

Straight-tusked mammoths

E. antiquns

(In France)

Bison

Bison? priscus
Stag
Cervus elaphus
FIRST INTERGLACIAL OE FRANCE

The Lower Pleistoeene deposits of Franee, which are approximately of the same age as the Forest Bed (Norfolk), are those of St. Prest (near Chartres), of Durfort (Gard), of Solilhae (near Puy) and the recently discovered phosphorite deposits of Cajare (Lot-et-Garonne) (Fig. 9, \%). All these beds are considered by Boule as of Upper Plioeene age: they are placed in the transition period between Pliocene and Pleistocene times by Harlé and Stehlin ${ }^{41}$ as well as by Depéret (St. Prestien).

We are disposed to consider all these deposits of approximately the same age as the Forest Bed, namely, Early Pleistoeene. In none of them have remains of primates, mastodons, tapirs or other eharacteristic Upper Pliocene mammals been found. On the other hand, these beds contain several forms surviving from the Pliorene, such as the southern mammoth (E. meridionalis), the etruscan rhinoceros ( $D$. etruscus), a primitive species of horse (E. stenonis), the giant hippopotamus (H. major), the giant bearer (Trogontherium). In France oecur the first remains attributed to the bison (B. priscus). In Durfort was

41 Harle, E., and Strhlix, H. G.: "Une Nouvelle Faune de Mammifères des Phosphorites du quercy." [Cajarc.] Bull. Soc. Géol. France, Ser. 4, Vol. IX, pp. 39-52. 1909. 
obtained the skeleton of the southern mammoth described by Gaudry. ${ }^{42}$ The giant deer (Megaceros) are represented at St. Prest by the species C. carnutorum, or "deer of the Carnutes."

The most recently discorered fauna of this age is that of Cajarc in the northern part of the Rhone basin. Harlé and Stehlin consider the Cajarc fauna as transitional between that of St, Prest and Durfort and that of Montmaurin which we attribute to Second Interglacial times. The mammoth (E. meridionatis) is of a more recent type than the Tpper Pliocene form of Italy. The bison is a very large animal. Especially important is the fact that these authors positirely identify here remains of deer which are related to the stag or red deer of Europe (C'ervus elaphus). learing the species doubtful. There is also at Cajarc a large badger (Weles tarus) which is characteristic of early Pleistocene times, and a small wolf (Canis) no larger than the jackal. There is also a small species of sabre-tooth tiger (Macherodus).

Southern Elephant (Elephas meridionatis). - The "southern elephant" is Faulkner's "pre-Glacial rariety of the mammoth." It belongs to the same general group as the other mammoths (E. trogontherii, E. primigenius) and the Columbian mammoth ( $E$. columbi) of America. The southern elephant of First Interglacial times
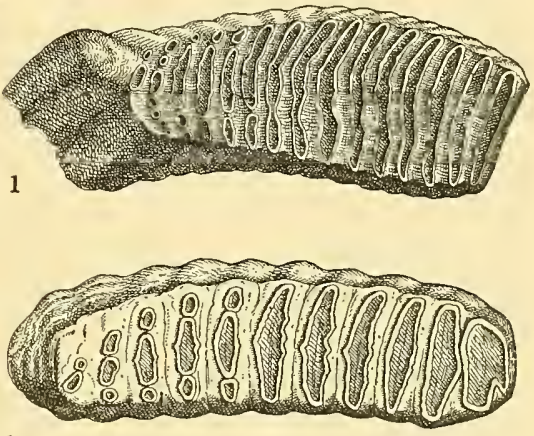

2

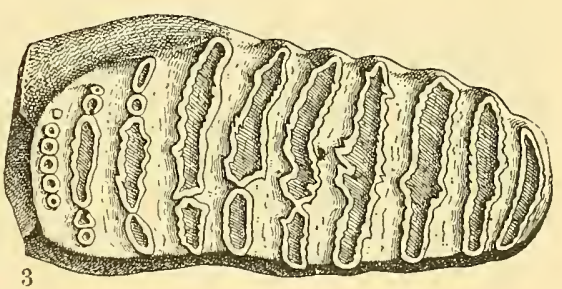

FIG. 11.- Molars of Pleistocene elephunts

(1) Elephas primigenius,

(2) Elephas antiquus,

(3) Elephas meridionatis.

After Lartet.

belongs to a somewhat more advanced type than that of the T'pper Pliocene of the Tal d'Armo: the Forest Bed specimens are, in fact, attributed by Pohlig ${ }^{43}$ to his species E. trogontherii. This mammoth series is distinguished both from the African (Loxodonta) and the Indian (Euelephas) elephants by the peculiarly flattened and concave forehead and the high. peaked cranium. It is probably descended from E. planifrons of the Pliocene and in tooth and skull structure it resembles the E. hysu-

42 GAUDrY, A.: L'Eléphant de Durfort. Yaris, 1883.

43 Poнlig, H. : "über Elephas trogontherii in England." Monatsber. Deutsch. Geol. res., Vol. f1, No. 5, pp. 242-249. 1909. 
dricus of the Upper Pliocene Siwaliks of India. 'Thus two distinct stages of the southern mammoth are known, the more primitive, occurring at the chose of the Tertiary in the Pliocene of the Val d'Arno, distinguished by very low, broad grinding teeth with thick enamel, the other more progressive stage, occurring in the Forest Bed, at Durfort, and in the Pleistocene deposits of the Tal d'Arno, and distinguished by dental plates of thimner enamel. The latter is said to be the original type of Yesti, who founded the species, but the matter of specific type requires investigation.

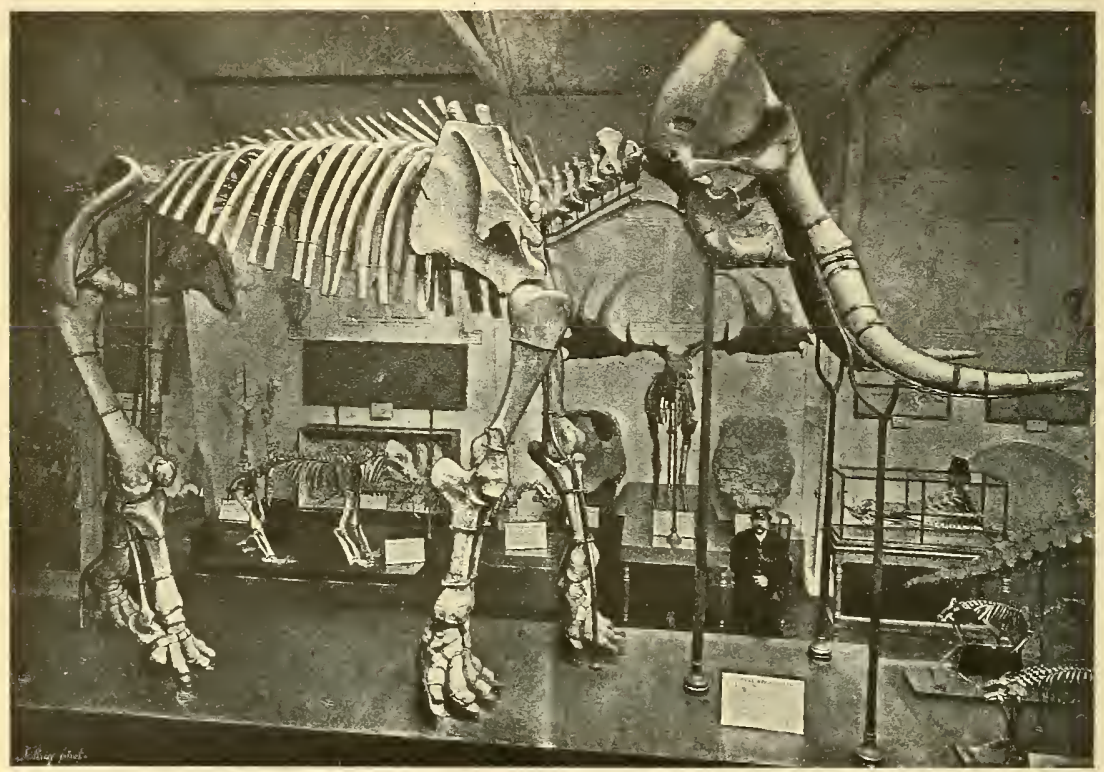

Fig. 12.-Skieleton of Elephas meridionalis of Durfort

Gallery of lalaontology in the Huseum dHistoire Naturelle. Jardin des I'lantrs, l'aris. After Gaudry.

The southern elephant is best known from the magnificent specimen found at Durfort and mounted under the direction of Gaudry in the Paris Museum. The height at the shoulders is $3.83 \mathrm{~m}$, or $12 \mathrm{ft} ., 9-1 / 5$ in. This animal was much taller than the true mammoth (E. primigenius) which first appears chiefly in the Third Glacial Stage. The tusks were shorter and less bent. We may infer from its original warm-temperate habitat that it was partially hairy but not corered with wool like E. primigenius.

The following table of comparison of the relative heights of the great Pleistocene and recent elephants is based so far as the extinct forms are concerned on a series of approximations because it is very difficult to 
estimate the height of these animals from the skeleton. In almost all cases of mounting these animals in museums the tips of the dorsal spines are unduly elevated above the superior spine of the scapula, which gives an exaggerated estimate of the height.

E. imperator, the imperial mammoth of North America,

$\overbrace{\text { English measule }}^{\begin{array}{c}\text { General estimated height at } \\ \text { shoulder }\end{array}}$

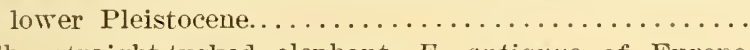

The straight-tusked elephant, E. antiquus of Europe,

(?) estimated (Pohlig, Pilgrim) at...........15' $16^{\prime}$

The southern elephant of Europe. E. meridionalis...... 12' $9^{\prime \prime}$

4.2672

$13^{\prime} 6^{\prime \prime}-14^{\prime}$

4.8768

3.8862

The largest living African elephant, L. africanus...... 11' $3^{\prime \prime}-11^{\prime} 4^{\prime \prime} 3.4544$

The Columbian mammoth of North America, E. columbi. $9^{\prime}-11^{\prime} \quad 3.3528$

The Indian elephant of Asia, $E$. indicus........... $9^{\prime} 10^{\prime \prime}-10^{\prime} \quad 3.048$

The true, or northern mammoth, E. primigenius (teste

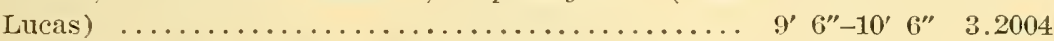

The living pigmy elephant of the Congo, L. cyclotis

pumilio (teste Hornaday)................. $4^{\prime} 5^{\prime \prime} \quad 1.3462$

The dwarfed elephant of Crete (E. antiquus creticus),

Malta (E. antiquus melitensis) and Cyprus........ 5

The American mastodon, Mastodon americanus........ $9^{\prime} 6^{\prime \prime} \quad 2.8956$

Hippopotami.-The hippopotamus is the invariable companion of the southern elephant and later of the Elephas trogontherii; it survived even in northern Europe until the middle of the Third Interglacial Stage. Outside of Asia the oldest hippopotamus remains known are from the Lower Pliocene of Gravitelli in Sicily; ${ }^{44}$ it is compared by Seguenza (1902) with the $H$. sivalensis of India but is clearly distinct from this species. The H. hipponensis of Gaudry is confined to the Middle Pliocene of North Africa and throws no light on the phylogeny of the hippopotami. These animals appear in the Lower Pliocene of India and of Sicily and in the closing Pliocene of Italy, India, and North Africa and perhaps China; in the Quaternary they spread into Java, India, Madagascar, Africa from north to south, the Mediterranean Islands, and from Spain and Italy on the south to England and west Germany on the north. Until additional data are secured it is difficult to decide whether this family originated in Africa (Stehlin, 1899) or in Asia (Schlosser, 1903).

Sabre Tooths.-Stromer ${ }^{45}$ has recently traced the history of the machærodonts in north Africa, Asia and Europe. A form closely similar to

\footnotetext{
44 Stroyer, ERnst: "Mitteilungen Über Wirbeltierreste aus dem Mittelpliocän des Natrontales (Ägypten). 3. Artiodactyla : Bunodontia: Flusspferd." Zeits. d. Deutsch. Geolog. Ges., Band 66, Abhandl., Heft 1, pp. 1-33. 1914.

45 Stromer, ERsst: "Mitteilungen Über Wirbeltierreste aus dem Mittelpliocän des Natrontales (Ägypten)." Zeitschr. d. Deutsch. Geologisch. Gesellschaft, Band 65, Abhandl., Heft 3 , pp. 350-372. 1913.
} 
M. aphanistus Kaup is the first known member of the sub-family to be discovered in Africa. He observes that the hyænas and otters (Lutra), the seals (Pristiphoca), and sabre tooths (Machorodus) speak strongly for a connection between North Africa (Egypt), Asia and Pliocene Europe. The sabre-tooth survives into the First, Second, and possibly into the Third Interglacial Stage (see note on Chellean culture).

Moose (Alces).--The earliest representative of the moose ${ }^{ \pm 6}$ is the Alces latifrons Dawkins from the Forest Bed of Cromer. It also occurs in the sands of Mosbach and of Mauer (Second Interglacial) and in the sands mnderlying the lower travertine layers of Taubach (Third Interglacial), always distinguished by the relatively simple palmation of its antlers from the existing A. machlis. The animal is also recorded in the Third Interglacial layer of Rixdorf and it survived in Germany into post-Neolithic times.

\section{PROBLEMATIC EVIDENCE OF MAN}

Saint-Prest is the most ancient Lower Pleistocene deposit in the basin of Paris. ${ }^{47}$ Coarse sands and gravels form part of the "high terrace" $50 \mathrm{~m}$. above the present level of the river Eure and contain a First Interglacial fauna of Elephas meridionalis and Equus stenonis as well as the "eoliths" known as Reutelien. This constitutes the Saint-Prestien stage of Depéret.

The locality of Saint-Prest is famous because in 1863 Desnover first reported the discovery of a number of bones with incision lines which he considered to be the work of man. These deposits were at the time regarded as Pliocene and gave rise to the theory of the occurrence of man in Pliocene times. The human origin of these incisions has long been a matter of dispute and is still doubtful. The associated fauna at SaintPrest includes the southern elephant, the etruscan rhinoceros, the hippopotamus, the giant beaver, three species of beaver and one of the bison. There is thus little doubt that this deposit is of First Interglacial age. Supposed confirmation of Desnoyer's discovery was the alleged finding by Abbott of several worked flints, two in situ, in the Cromer Forest Bed.

This question has become more or less identified with the eolithic theory which postulates a long stage of the artificial use of flints antecedent to the pre-Chellean and Chellean Stages, which are here considered as belonging in the Third Glacial Stage, although some authors place the pre-Chellean in the First Interglacial Stage.

\footnotetext{
4 Dietrich, W. O.: "Neue fossile Cervidenreste aus Schwaben," Jahresheite des Vereins f. vaterlänđische Naturkunde, Jahrg. 66, pp. 320-336. 1910.

${ }^{47} \mathrm{HAUG}$, Emile: "Traité de Géologie. II. Les Périodes géologiques," p. 1807. Libr. Armiand Colin, Paris, 1908-1911.
} 
Eolithic Theory. ${ }^{ \pm}$-Following Desnoyer's discorery in 1863 was that of L'Abbé Bourgeois in 186\%, who found in the Miocene of Thenay, Loire-et-Cher, flints supposed to be the work of man. In $18 \% \%$ Rames brought to notice flints from the Upper Miocene volcanic ash beds of Puy-Cournay. Cantal. in central France. In 1892 Brown proposed the term "eoliths" to distinguish these supposedly primitive artifacts from the "palæoliths" of Lubbock (Fig. 13). The Belgian geologist Rutot has deroted many years to the derelopment of the eolithic theory and has
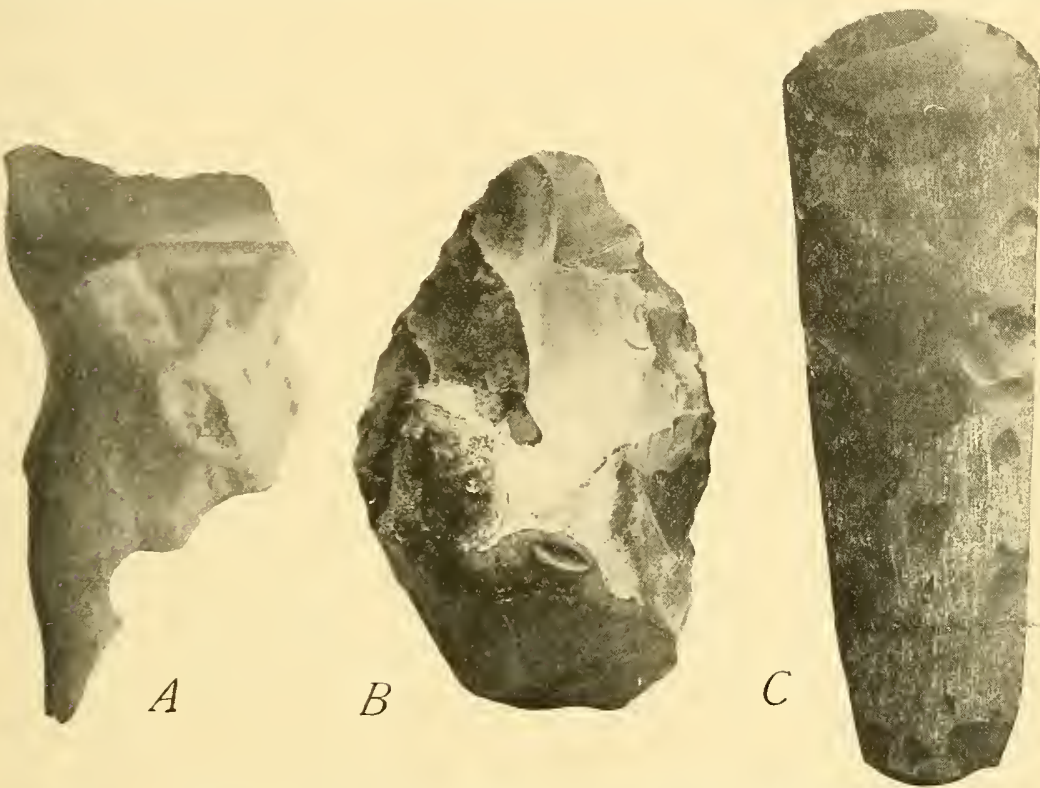

F'IG. 13.-Eolithic, Paloolithic and Neolithic implements

d Eolith, Mafflean Epoch, Belgium, B Palæolith, Chellean Epoch, Milton street, Kent, England. $C$ Neolith, Upper Robenhausian Epoch, Gille Leie, Denmark. Photograph by MacCurdy, 1909.

attempted to prove that like the Palæolithic the Eolithic period is capable of subdivision into a number of stages or industries which are geologically demonstrable.

The supposed eolithic flints are very rough, but rude as they are they generally exhibit one part shaped as if to be grasped by the hand while the other part appears to be edged or pointed for cutting. ${ }^{49}$ It is gener-

\footnotetext{
48 MacCurdr, G. G.: "The Eolithic Problem. Evidences of a Rude Industry Antedating the Paleolithic." Amer. Anthropol., N. S., Vol. VII, No. 3, pp. 425-479. July-Sept., 1905 .

49 PeNck, A. : "The Antiquity of Man." Lecture before Washington Acad. of Sci., Feb. 1, 1909. Abstr. Science, X. S., Vol. xxix, No. 739, pp. 359-360. Feb. 26, 1909.
} 
ally admitted that these flints are mostly of accidental shapes and show little or no proof of being fashioned by human hands. The chief difficulty in the eolithic theory is that flints of a similar character occur in deposits of Upper Oligocene agc (Rutot) and may even be found in deposits of Lower Eocene age (Breuil). 'The leading French archæologists, Cartailhac, Breuil, Obermaicr, Boule, accordingly reject the eolithic theory entirely. Breuil considers that the various eolithic shapes are entirely accidental products due to pressure of closely compacted flints. Boule observes :50 "As to the 'eoliths' I have combatted the theory not only because it seems to me improbable, but because a long geological experience has shown me that it is often impossible to distinguish stones split, cut or 'retouched' by purely physical agents from certain products of rudimentary workmanship."

It does not appear that the eolithic theory has been strengthened in recent years. If eoliths are to be regarded as human artifacts the antiquity of man or of a prehuman type given to shaping stone implements would be vastly increased. It is probable that the ancestors of early man possessed grasping power of the hand. The only known Miocene and Pliocene primate of Europe which might be considered as an eolithmaker or eolith-user is Dryopithecus; all the other known pre-Pleistocene primates belong to some one of the existing phyla of monkeys, baboons, or apes.

Pithecanthropus erectus.-Of late Pliocenc or early Pleistocene age is the Pithecanthropus erectus of Trinil, Java, discovered by the Dutch army surgeon Eugen Dubois in the year 1891. The remains were recorded by Dubois as of Upper Pliocene age because of their association with a rich fauna containing Stegodon ganesa, Elephas hysudricus, and other mammals similar to those of the Upper Pliocene of the Siwaliks of India. Reëxamination of the Kendeng stratum in which Pithecanthropus occurs, by Holz (190\%), Elbert (1908) and others appears to demonstrate that the Pithecanthropus occurs in strata corresponding with an early Pluvial period following a period of low temperature which wonld appear to accord with the early Pleistocene of Europe. It is therefore gcnerally agreed that Pithecanthropus is of early Pleistocene age. Following the monographic description of this very important type by its discoverer Dubois ${ }^{51}$ was the keen analysis of Schwalbe, ${ }^{52}$ who rcgards

\footnotetext{
${ }^{50}$ Boule, Marcellin : "L'Homme fossile de la Chapelle-aux-Saints." Ann. de Palæont. Vol. V1, pp. 111-172, pll. XVII-XX, 1911; Vol. VII, pp. 21-192, pll. IV-XIX, 1912: Tol. V111, pp. 1-T1, 1913.

51 Dubors, Eug. : "Pithecanthropus erectus. Eine Menschenaehnliche Uebergangsform aus Java." 4to. Landesdruckerei, :39 pp., 2 pll. Batavia, Java, 1894.

${ }^{52}$ Schwalbe, G.: "Ueber fossile Primaten und ihre Bedeutung für die Vorgeschichte. des Menschen." Mitteil. Philomat. Ges. Elsass-Iothringen, Vol. IV; No. 1, Decade 16. 1908. Strassburg, 1909 .
} 
these remains as representing either a direct or indirect ancestor of a human phylum which stands intermediate between that of the apes and Teanderthal man ( $H$. neanderthalensis) both in respect to its high brain capacity and the structure of its femur. The unusually straight femur indicates an erect attitude, to which the specific name $P$. erectus applies; in fact, from the structure of the thigh bone Dubois concluded that the "Trinil Ape-Man" had free use of the arm and hand, which were now no longer required for locomotion, and that the hand was already far advanced in the line of differentiation which developed it into an organ of touch and capable of fashioning tools.

\section{LIFE OF THE MEDITERRANEAN ISLANDS}

It appears that the continental elevation of southern Europe in early Pleistocene times established migrating routes or land connections between the islands of the Mediterranean with Europe on the north and Africa on the south. Rütimeyer (1869) was one of the first to maintain that north Africa, including Morocco, Algeria and 'T'unis, was stocked with mammals by way of Gibraltar and perhaps also by way of Sicily and Malta. In the islands of Malta, Cyprus and Crete as recently explored by Bate $^{53}$ we have proof, first, of a long period of connection with the neighboring continents through elevation, and second, of the isolation of the islands through subsidence. The isolation is followed by the dwarfing of several types of large mammals which, confined on the islands were made captive by the sea. Pohlig believes ${ }^{54}$ that toward the end of the First Glacial Stage large mammals migrated to Sicily which at that time was connected both with Europe and Africa. The land bridges then became submerged and the large mammals dwindled in proportions through interbreeding and isolation into dwarf races. It appears probable that Cyprus became isolated as an island first, because the extinct Elephas cypriotes and Hippopotamus minutus are both more primitive than the species of Malta and Sicily. That Malta retained its connection with Sicily for a long period is indicated by the common occurrence in the cavern deposits on both islands of the two species Elephas mnaidriensis and Hippopotamus pentlandi. The dwarf elephant race (E. melitensis) characteristic of Malta has also been found on the mainland near Rome, which would seem to indicate that land connection between the Italian mainland and Malta was renewed more than once.

\footnotetext{
${ }^{5}$ Bate, D. M. A. : "On Elephant Remains from Crete, with Description of Elephas creticus sp. n.," Proc. Zoöl. Soc. London, pp. 238-250. Aug. 1, 1907.

¿4 Pонцig, Н. : "Eine Elephantenhöhle Siciliens und der erste Nachweis des Cranialdomes von Elephas antigmms," Abhand. kïnigl. bayer. Akad. Wissensch., cl. ii, Bd. xriil, Abth. 1, pp. 75-109. pll. i-v. 1895. Sep. Tunich, 1893.
} 
The diminutive elephants of the Mediterranean islands were all descendants of the straight-tusked species $E$. antiquus. The researches of Bate confirm this relationship. They attained a height not exceeding fire feet. The adaptability to which $E$. antiquus owed its wide geographic distribution and continued existence through a long period of time may account for its surviral in the Mediterranean islands despite rapid diminution in size under adverse circumstances. The true African elephant (Loxodonta) never crossed the Mediterranean.

The reduced existing fauna of the Island of Cyprus contains a mingling of Eurasiatic and north African mammals and shows the effects of deforestation in historic times. Descendants of Eurasiatic ancestors prevail in the Mediterranean islands. The recently discovered Myotragus balearicus of the Pleistocene cave deposits of the Island of Majorca is now regarded as related to the Rupicaprinæ or Alpine chamois type (Andrews).

\section{Second Glactal Stage-Satoniar, Mrndel, Kansan}

The second glaciation was the greatest both in Europe and America. We observe that the most extended drift sheets are those in the Scandinavian region, on the British Isles, around the northern Swiss Alps, and from the Keewatin center west of Hudson Bay in British America. The whole rise and fall of the Mindel glaciation in the Alps is estimated by Penck as occupying a very long period of time. The snow line in the Alpine region descended $1,300 \mathrm{~m}$. lower than at the present time.

The only notable exceptions are in the Labrador region of eastern North America where the main ice field was formed at a later stage, known as the Illinoian. It also appears that the Third Glacial or Riss drift of the western Alps is the greatest in that region and of similar age to the Illinoian.

In this second glacial advance the Scandinavian ice field reached its farthest southerly limits. In northwestern Europe this main Saxonian (Geikie) glaciation extended to the northern slopes of the Carpathians, the Sudetes, the Erz Gebirge, the Thuringian and the Harz Mountains. From these ice sheets were given off the "Older Drift," or "Lower Diluvium" of northern Germany, and in the Swiss Alps this Second glaciation sent out its Mindel drift as the most extensive fringe along the northern borders of the Alps; on the eastern and southern borders of the Alps the Second Glaciation was about as extensive as the Third glaciation; on the western borders of the Alps the Second glaciation was less extensive than the Third. Similar conditions prevailed in America; from the Keewatin Centre the ice cap extended its drift southward into 
Missouri. Iowa, Kansas and Nebraska beyond the limits both of the First and the Fourth glaciation.

Thus the Saxonian drift of North Germany, the Mindel drift of the Smiss Alps and the Kansas drift of America are correlated (Penck, Leverett) both by their great antiquity and by their very wide extent. The eminent geologist Wahnschaffe, however. correlates the "Old Drift" of the north German lowland with the Third or Riss glaciation instead of with the Second.

\section{Śecoxd Ixterglactal Stage-Minuel-Riss}

Penck regards the Second Interglacial or Mindel-Riss Stage as by far the longest of the interglacial intervals in the Alpine region, estimating the period between the maximum Second glaciation (Mindel) and maximum Third (Riss) as high as 360,000 years. In America also by comparing the erosion of the Second Glacial (Kansan) drifts with those of the Third Glacial (Illinoian) drifts it would appear that the Second Interglacial Yarmouth Stage was of greater duration than the entire mterval between the Third Glacial and present time. In the north German lowlands it is shown to be a long interval from the amount of sedimentation effected by the interglacial rivers and streams, but whether in this region it is longer than the First Interglacial Stage is doubtful (Leverett, 1910, p. 273).

\section{MOISTURE FOLLOWED BI ARIDITY}

In course of this long warm Second Interglacial Stage the climate again moderated, becoming slightly warmer than the climate of to-day. The climate immediately following the retreat of the ice was cool and moist, then followed a long warm stage, but this stage was finally succeeded by a period of aridity both in Enrope and America in which the first loess deposits occurred. In Russia also the Second Interglacial seems to begin with a cool and moist phase followed by a more arid or steppelike climate farorable to the deposition of loess. It would appear that the height of the interglacial aridity was reached during the deposition of the loess. The "Older Loess" deposition certainly began both in Europe and America during the Second Interglacial Stage although in neither country is the "Older Loess" so continuous or so thick a deposit as the "Nerrer Loess." In Europe the "Old Loess" lies between the "Old Drift" of the First and Second Glacial advances and the "Middle Drift" of the Third Glacial advance. At Mauer near Heidelberg the loess lies immediately above the Upper Mauer sand layer which contains an arctictundra famna (Förster, 1913). The rarious lavers of loess are of the 
utmost importance both in Europe and America in the correlation of human and mammalian life, also in their significance as to the climate of interglacial times. Loess consists of a fine, porous, silicious, calcarcous silt, usually of light brown color, characterized by a peculiar competency to stand in vertical walls during erosion. Its origin and transportation a se believed to have been partly sub-glacial, partly fluviatile, partly aeolian. The fine mud carried by the sub-glacial streams in glacial times became desiccated and redistributed by the wind. Penck (1904) describes the Pleistocene loess as formed in districts traversed periodically by great streams leaving dry mud which in arid periods was redistributed by æolian agencies. Its Pleistocene distribution is quite independent of altitude since it occurs in the interglacial deposits of Europe from sea level to a height of $1,500 \mathrm{~m}$.

\section{CLIMATE}

A considerable part of the elevation of the Swiss Alps apparently took place (Penck, 1910) during the Second Interglacial Stage, and this increased altitude is considered by some European authorities to be the cause of the greater extent of the Third glaciation in the western Alps.

The Höttinger breccia near Innsbruck is referred by Penck (1909, p. $115 \%$ ) to the Second Interglacial Stage with its rich flora indicating a climate warmer than that of present times; this breccia lies on one of the old "High Terraces" of Second Interglacial times. The plants include the fir (Pinus sylvestris), spruce (Picea sp.), maple (Acer psendoplatanus), buckthorn (Rhamnus frangula), several willows (Salir nigricans. S. glabra, S. incana, S. triandra), the wayfaring tree (Tiburnum lantana), yew (Taxus baccata), elm (Ulmus campestris), strawberry (Fragaria vesca), self-heal (Prunella vulgaris), beech (Fagus silvatica), and mountain ash (Sorbus aucuparia), buckthorn (Rhamnus Hottingensis), related most closely to $R$. latifolia, now living in the Canary Isles, the box (Buxus sempervirens), also a southern species; and most important of all a rhododendron ( $R$. ponticum) which now lives in the Caucasus five degrees south of the latitude of Innsbruck and in a climate on the average $3^{\circ} \mathrm{C}$. warmer. 'Taking all the facts into consideration Penck concludes that the climate of Innsbruck in the days of the Hötting breccia was $2^{\circ} \mathrm{C}$. higher than it is now. In correspondence with this the snow-line stood 1,000 ft. above its present level, and the Alps save for the higher peaks were almost completely denuded of ice and snow. ${ }^{55}$

A picture of the flora of the Second long warm Interglacial Stage is also afforded in the Quaternary tuffs of Provence, where the remains of

55 Sollas, W. J.: Ancient Hunters and their Modern Representatives, p. 27. 870. MacMillan \& Co. London, 1911. 
plants are associated with elephants of the $E$. antiquus stage. "The flora of the Quaternary tuffs," observes Saporta, ${ }^{56}$ "is composed almost entirely of woody forms living in valleys and by the sides of streams." It is for the most part analogous with the present flora of Provence. Of the thirty-seren species, twenty-nine still occur in this region. Among the forms which have since retreated to the south are the sweet bay (Laurus nobitis) and another species of laurel ( $L$. canariensis) which is now confined to the Canaries. The greater humidity of the time is indicated by the presence of species of pine which require more moisture. As in the Torfolk Interglacial, the figs (Ficus) and the Judas trees (Cercis) flourished. The ash (Fraxinus) is of a species now found in Corsica and Italy. On the whole, the forest trees and forest ground flora are surprisingly modern, including oaks, elms, poplars, willows, lindens, maples, sumacs, dogwood. hawthorn. Among the climbing plants are the vine (Vitis) and clematis (Clematis).

\section{MATMALS}

This life period was first observed by Lyell and Evans in Essex, England, and was subsequently recognized in Germany and France. Geologically the deposits are partly of fluviatile origin, consisting chiefly of river sands and gravels in which the remains of hippopotamus, elephants and rhinoceroses occur. These animals were formerly cited as proof of an almost tropical climate, but the evidence of the flora, enumerated above, and the equally numerous hardy types of animals tend to modify the former theories as to extremely warm Second Interglacial temperatures. The geographic connections of Europe with the south through the land bridges of Lower Pleistocene times still persisted in Italy in whole or in part, because the depression of the southern portion of the continent of Europe had not yet begun.

Survivals.-The mammals occurring in these Older Diluvial sands and gravels include several Pliocene survivals from the First Interglacial Stage, associated with the etruscan rhinoceros (Dicerorhinus etruscus). If Montmaurin belongs to this stage we may include Machcerodus. At Mauer two primitive types of bear, Ursus arvernensis and $U$. deningeri, are recorded, also Trogontherium cuvieri. The Mauer horse first identified as E. stenonis is now referred to E. mauerensis.

Among the chief localities where the river deposits containing the mammals referred to the Second Interglacial Stage occur are the following :

50 DE SAporta, G. : "La Flore des Tufs Quaternaires en Provence." C. R. Sess. Congr. Sci. France. Aix, 1.967 . 
Early Phase. Warm Fauna.

Mauer Sands (Lower), near Heidelberg, Germany. Warm Fauma.

Montmaurin (Haute Garonne), Pyrenees, France.

St. Roche, France.

Middle Phase.

Mosbach, near the Neckar in northern Baden (Fig. 9, 12).

Süssenborn, near Weimar, Germany (11).

Iater Phase. Cold Tundra Fauna.

Maner Sands (Upper), near Heidelbers. Germany (14). Cold Fauna approaching the Third Glacial Stage.

Extinctions.-The mammals of this grand life zone have lost nearly all resemblance to those of Upper Pliocene times with the exception of the survival of the etruscan rhinoceros and possibly of the sabre-tooth tiger. The polycladine deer of Upper Pliocene times and of the Norfolk Forest Bed, or First Interglacial, have ranished; neither are there any traces of the axis deer (C. axis).

Arrivals.-The Second Interglacial Stage is readily distinguished both in France and Great Britain by a number of important new arrivals, chief among which are the "old elephant" (E. antiquus) and the broadnosed rhinoceros (D. merchii). Another very important arrival is the lion related to the African Felis leo. The southern elephant has now certainly passed into the Elephas trogontherii stage of Pohlig for the type specimen of this intermediate species occurs at Süssenborn; in fact, this is the "E. trogontherii stage" of Pohlig; it is also known as the "older E. antiquus" stage by Schmidt and other authors. The southern mammoth E. (meridionalis) trogontherii is replaced by the more progressive and typical $E$. trogontherii. The broad-faced moose (Alces latifrons), the giant deer (Megaceros) and the roe deer (Capreolus) are all present in the cooler and forested phases of this interglacial period. The true stag (Cervus elaphus) is certainly recorded. The cattle (Bos primigenius) begin to be numerous and the bison (Bison priscus) also appear in numbers. Horses of larger size occur (E. mosbachensis, E. süssenbornensis).

Among the river-living forms are the beavers (Castor). The giant beaver (Trogontherium) is by some authors said to make its last appearance in Europe in this sub-stage, but it is again recorded in the Third Interglacial at Chelles. Other rodents include the marmots (Marmolta) now found in the Alps, Carpathians and Pyrenees, whose remains may have been borne down by the streams. Beside the lions the carnivores include the typical Eurasiatic forest forms, namely, the lynx (F. Tynx), two varieties of bear ( $U$. deningeri, $U$. arvernensis), and the badger (Meles).

The chief components of the fauna of the Second Interglacial Stage 
are seen to belong, first, to the Eurasiatic Forest and Meadow Fauna, only separated by specific and sub-specific differences from the Prehistoric Fauna of Europe; second, to the surviving African-Asiatic fauna, including the hippopotamus, two very distinct kinds of elephant, and two rhinoceroses; third, there is evidence in the late colder phases of this period of the first occurrence in Europe of the Tundra Fauna as represented by the reindeer (Rangifer tarandus). This animal is recorded in the gravels of Süssenborn by Weiss. Hilzheimer ${ }^{57}$ also speaks of the remains of reindeer as occurring both in Siissenborn and Steinheim in association with the remains of $E$. trogontherii. This author regards $E$. trogontherii from the structure of its grinding teeth as analogous in habit to the Asiatic elephant which inhabits the forests of India, and believes that the presence of this animal indicates a relatively moist climate and well forested country.

Africax-Asiatic Types

Primates

Homo heidelbergensis

Africax-Astatrc Fauna

Straight-tusked elephant

E. antiquиs

Trogontherian mammoth

E. trogontherii

Broad-nosed rhinoceros

D. merckii

Etruscan rhinoceros

D. etruscus

Hippopotamus

H. major

(?) Sabre-tooth tiger Machorodus

Lion

Felis teo spelea

Eurasiatic Hardy Fauna

Urus

Bos primigenius

Bison

Bison priscus

Stas. roe deer, moose, siant deer

Bear. lrns, badger. wild cat

(Late)

Reindeer

Rongifer tarandus
In this assemblage it is noteworthy that the Eurasiatic Forest and hardy temperate types greatly predominate over the African-Asiatic types. This is another indication that the climate was of a warm-temperate character rather than such as now characterizes southern Asia and Africa. It follows that all the African-Asiatic mammals may have been well protected by hairy covering and adapted to a temperate climate.

In the caverns near Montmaurin in the Pyrenees ${ }^{58}$ we find remains of an early Pleistocene fauna which contains the sabre-tooth tiger ( $M$. Tatidens). the broad-nosed rhinoceros (D. merckii), the stag ( $C$. elaphus), the brown hyæna (II. brunnea striata).

The most typical fauna is that of Mosbach in northern Baden. Here there occur all the characteristic mammalian types of the period, the hippopotamus, the urus, the bison,

\footnotetext{
57 Hrlzhermer, Max: Handbuch der Biologie der Wirbeltiere, pp. 67S-679. Stuttgart, 1912-1913.

58 Bodle, M. : "La Caverne à Ossements de Montmaurin (Haute-Garonne)." L'Anthropol., Vol. XIII, pp. 305-319. 1902.
} 
the broad-nosed rhinoceros, two species of mammoth ( $E$. antiquus, $E$. trogontherii), and the horse (E. mosbachensis).

In the Lower sands of Mauer near Heidelberg there occur the first recorded remains of man and a fauna including some primitive species.

Homo heidelbergensis. - To the faunal stage of Elephas antiquus and the etruscan rhinoceros (D. etruscus) is to be added the Heidelberg man, determined from a lower jaw discovered by Otto Schötensack ${ }^{59}$ in $190 \%$ in the Lower Mauer Sands at a depth of $24.10 \mathrm{~m}$., one of the most important discoveries in the whole history of anthropology. The lower jaw is exceptionally massive, without chin projection, with a large but essen-

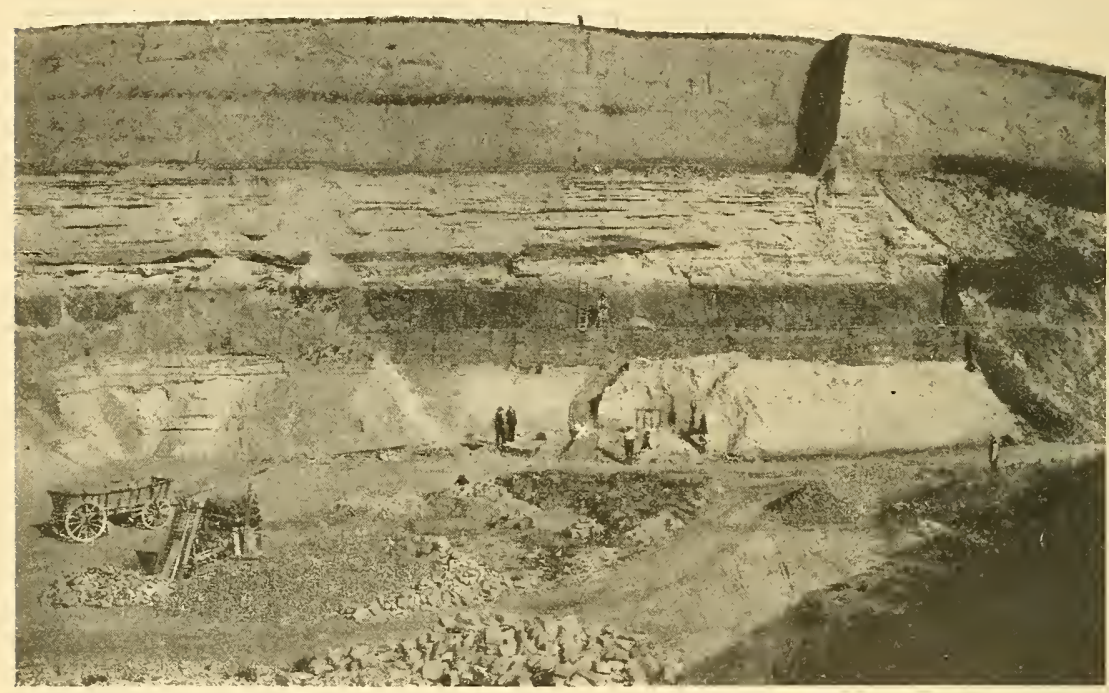

FIG. 14.- Sand pit at Mauer near Heidelberg

The lower jaw (Homo heidelbergensis) was found at the spot marked with a cross. After Schoetensack and MacCurdy.

tially human set of teeth; in other words, it is a jaw in some respects similar to that of an anthropoid ape but containing the dentition of a man, namely, typically human canine and molar teeth. The jaw is now regarded by anatomists as resembling on a very massive and primitive scale the jaw of the neanderthaloid human type (Homo neanderthalensis) which first occurs in the Third Interglacial Stage.

The fauna associated with Homo heidelbergensis is of an ancient char-

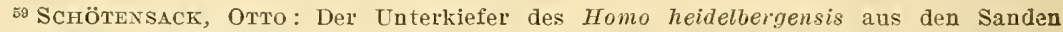
von Mauer bei Heidelberg: Ein Reitrag zur Paläontologie des Menschen. Verlag von Wilhelm Engelmann. Ieipzig, 1908.
} 
acter. Schötensack likened it to that of the First Interglacial or Norfolkian Stage. The presence of the etruscan rhinoceros would appear to justify this opinion, but it is overborne by the similarity to the fauna of Mosbach including the presence of Equus mosbachensis, a species highly characteristic of the Second Interglacial Stage. The entire fauna of these Lower Sands of Mauer is now identified (Schmidt, 1912), as follows: Elephas antiquus, D. (Pliinoceros) etruscus, ${ }^{60}$ Equus mosbachensis, Sus scrofa ferce, Alces latifrons, Cervus elaphus, Capreolus capreolus, Bison priscus, Bos primigenius, Ursus arvernensis, U. deningeri, Felis leo, ${ }^{61}$ Felis catus, Canis neschersensis, Castor fiber. The enumeration of

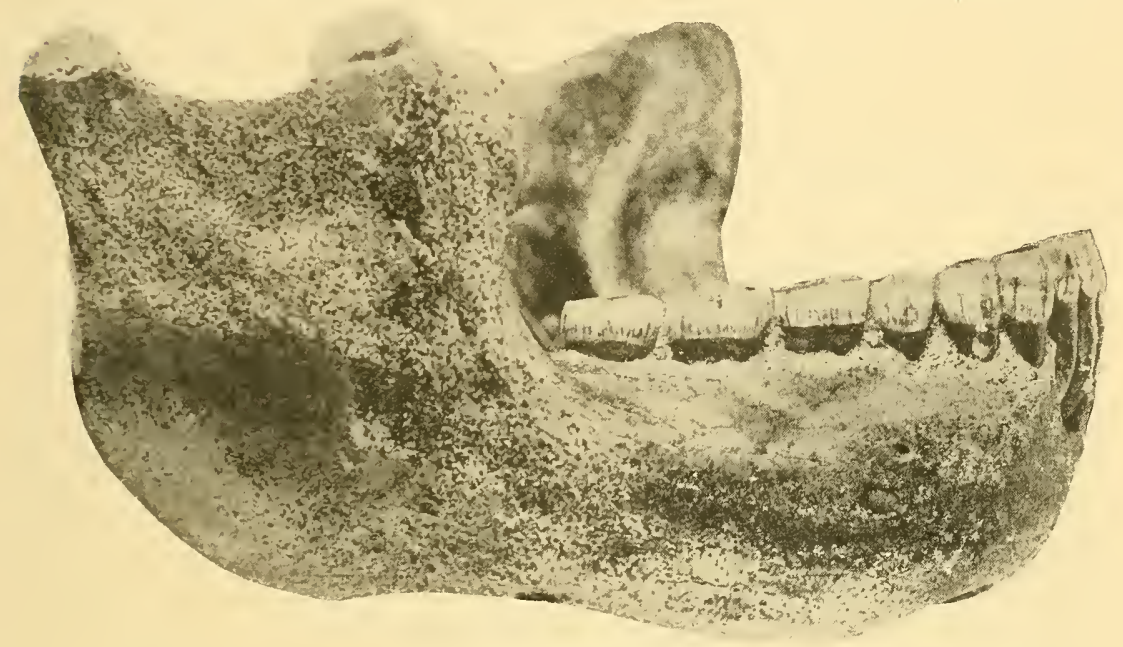

F1G. 15.-Heiliellery jow

The human lower jaw ( $3 / 4$ natural size) found near Heidelberg. on which is based the species Homo heidelbergensis. After Schoetensack.

this fauna is very important as indicating the temperate climatic conditions which surrounded the Heidelberg man. Wurm observes that the Etruscan rhinoceros only occurs in Mauer and that its variations indicate a transition towards the D. merckii which occurs at Mosbach and Süssenborn but not in Mauer. Above this layer occurs a deposit of the "Older Loess," indicating an arid climate. The Upper Sands of Mauer contain a cold fauna which by some is referred to the close of the Second

\footnotetext{
60 Wurs, A.: “Ủber Rhinoceros etruscus Falc. von Mauer a. d. Elsenz (bei Heidelberg)." Verh. d. Naturhist.-Medizin. Vereins zu Heidelberg, N. F. XII Band, 1 Heft, pp. 1-62, pll. I-IV. 1912 .

a Wurs, A. : Beiträge zur Kenntnis der Diluvialen Säugetier fauna von Mauer a. d. Elsenz (bei Heidelberg), I. Felis leo fossitis. Jahresberichte und Mitteilungen des Oberrhein. geol. Vereins, N. F., Bd. II, Heft 1, pp. 77-102. 1912.
} 
Interglacial stage, by others (Turm,6" 1913, p. 68) to the "Younger Luess:" that is, tu the Fourth Glacial or Postglacial stage.

\section{CHELLEAN CULTURE WITH ANCIENT INLERGLACIAL FAUNA}

In favor of the antiquity of the Chellean culture may be urged the fact of its association in several localities (Torralba, Abbeville, Piltdown) with the primitive mammals identified as Machcerodus, D. etruscus, Equus stenonis. The specific identifications may be incorrect, but these Pliocene species are characteristic of the Second Interglacial Stage and are not certainly recorded in the Third Interglacial Stage of northern Europe at least. For example, at Torralba, Province of Soria, Spain, there has been discovered (Harlé, 1910, p. Y5) an old typical Chellean camping site containing abundant remains of $D$. merckii and E. meridionalis (trogontherii) mingled with remains of other mammals of primitive type identified as Dicerorhinus etruscus and Equus stenonis. These associations with Chellean remains tend to support the theory that the Chellean culture began during the Second Interglacial Stage. Another very ancient fauna associated with very primitive Chellean or pre-Chellean implements is that found near Abbeville, Gisement de Champ de Mars. ${ }^{63}$ Beside typical members (such as E. antiquus, E. meridionalis trogontherii, and $D$. merchii) of warm Second Interglacial times this fauna is said to contain such primitive types as Trogontherium, $D$. etruscus, Equus stenonis, also very numerons specimens of Macharodus and Hycena brevirostris.

We cannot fully agree with Schmidt (1912) when he observes that the faunal separation of the Acheulean and Chellean is not so marked that we are obliged to separate these cultures by a long period of time.

FAINA OF THE PYRENEES, CANTABRIAN ALPS, SPAIN AND PORTUGAL ${ }^{64}$

The entire warm fauna characteristic of Germany, Great Britain and France also penetrated the Cantabrian Alps, Spain and Portugal as far south as Gibraltar.

A macaque (Macacus) related to the Algerian species occurs in the grotto of Montsauné (Haute Garonne) associated with the hyæna ( $H$.

\footnotetext{
62 Wurm, A.: "Úber eine Neuentdeckte Steppenfauna von Mauer an der Elsenz (bel Heidelberg)." Jahresber. u. Mitt. d. Oberrhein. geol. Vereins, N. F., Bd. III, Heft 1, pp. 62-78, pl. vi. 1913.

${ }^{3}$ D'Ault du Mesile, G.: "Note sur le Terrain Quaternaire des Environs d'Abbeville." Revue Mensuelle de l'École d'Anthropologie de Paris, VI year, pp. 285-296. 1896.

ot Harle, Edorard: "Les mammifères et oiseaux quaternaires connus jusqu'ici en Portugal. Memoires suivi d'une liste générale de ceux de la Peninsule Ibérique." Commun. du Servise Géol. du Portugal, T. viii, pp. 22-85, pll. I-V. 1910.
} 
striata), with a dhole (Cyon), and other members of the warm fauna of $E$. antiquus and D. merckii. The porcupine (Hystrix cristata) also occurs here.

The striped hyæna (H. striata brunnea) is associated with Machorodus latidens in the cavern of Montmaurin (Haute Garonne). The striped hræna occurs at five other localities in the Pyrenees, Spain and Portugal (Furminha); it has also been recognized in Germany (Mosbach), Austria (Hundsheim) and France (Harlé, 1910, p. 40); it disappears later or retires to the south, while the spotted hyæna (H. crocuta spelcea) becomes adapted to the extreme cold and survives with the reindeer to the end of Postglacial times. The Carnivora of this region are Felis leo spelca, the panther (Felis pardus), the wild cat (Felis catus), and the lynx (Felis pardina).

\section{Second and Third Glachal and Interglacral Epochs}

\section{AFRICAN-ASLATIC FAUNA}

Four great animals especially characterize this fauna: Elephas trogontherii and Hippopotamus major, Dicerorhinus merckii and Elephas antiquus.

Old Elephant (Elephas antiquus). ${ }^{65}$-The "old elephant" or straighttusked elephant (Elephas antiquus) does not occur in France or Great Britain until the Second Interglacial Stage, but it is said to occur in the Arno valley of Italy during an earlier stage in which it is associated with a warm fauna including the southern mammoth and the hippopotamus. The typical $E$. antiquus is recognized by its narrow, elongated grinding teeth with comparatively few plates which, combined with its skull characters, suggest its affinity to the modern African (Loxodonta) rather than to the Indian elephant (Euelephas) group. While during the first, or Norfolk, interglacial period it is confined to Italy, in subsequent interglacial times it wandered into northern Europe as one of the grandest and most distinctive forms, attaining a very wide distribution. Pohlig certainly orerestimates its $\operatorname{size}^{66}$ in assigning to it a height of $5 \mathrm{~m}$. at the back (16 ft. $8 \mathrm{in}$.), or $1 \mathrm{~m}$. more than the mammoth, and with tusks also $5 \mathrm{~m}$. in length. In consequence of the size and weight of the tusks, the head, shoulders and fore legs were enormously developed. The same writer believes that the habitat of this mammoth retreated and advanced

\footnotetext{
е PoHLig, H.: "Dentition und Kraniologie des Elephas antiquus Fale. mit Beiträgen über Elephas primigenius Blum. und Elephas meridionalis Nesti." Nov. Act. Ksl. Leop.Carol. Deutsch. Akad. Naturforsch., Vol. LIII, No. 1, p. 326. Halle, 1888.

Poflis, H. : Eiszeit und Urgeschichte des Menschen. Leipzig. 190\%.
} 
with the successive ice waves and warm interglacial times. Because of the resemblance of the grinding teeth of $E$. antiquus to those of the African elephant (L. africanus) it has been assumed perhaps too readily that this ancient elephant was characteristic of a tropical climate. It resembles the African elephant in the prominence of the enamel bands of the grinding teeth, which are adapted to the comminution of twigs and woody food, which justifies the belief that this animal frequented the forests. For these reasons Hilzheimer regards E. antiquus as indicative of forest conditions.

Rhinoceroses.-The three great rhinoceroses characteristic of the European Pleistocene are each of distinct geological value. In general $D$. etruscus belongs to the First Interglacial Stage, D. merckii characterizes the Second Interglacial Stage and most of the Third Interglacial, while D. antiquitatis is distinctive of the Fourth Glacial and the Postglacial.

The two species first named are apparently related to the Sumatran phylum (Dicerorhinus sumatrensis). The D. etruscus of the Val d'Arno, of the First Interglacial and of the early phases of the Second Interglacial is a relatively small animal, distinguished by brachyodont grinding teeth and long, slender limbs, a small anterior and a larger posterior horn. It is remotely related to the Sumatran rhinoceros but differs in the absence of cutting, or incisor teeth. It is essentially a browsing type. Its remains in Mauer are said ( $\mathrm{Wurm}, 1912$ ) to afford a transition to $D$. merckii.

Related to this animal in the Second Interglacial Stage in Great Britain, Germany, France, Italy, there appears the broad-nosed rhinoceros known as $D$. megarhinus, or $D$. merckii. It resembles $D$. etruscus in its smaller anterior and larger posterior horn and in the elongation of its limbs and feet, but differs from it in the possession of relatively longcrowned (hypsodont) grinding teeth adapted to grazing habits. This animal is very widely distributed geographically in the Second and the first half of the Third Interglacial Stage, and is in most localities associated with remains of the hippopotamus and "old elephant."

Quite distinct from these animals is the woolly rhinoceros (Diceros antiquitatis, D. tichorhinus) which belongs with the colder climates of tundra and steppe conditions and is almost invariably associated with remains of the true woolly mammoth (E. primigenius). Like the above described Sumatran species it lacks the front, or cutting teeth and has in consequence been improperly considered as related to Dicerorhinus, but really belongs to the modern African group of Diceros, resembling espe(ially the species $D$. simus, with which it closely agrees in its dolicho- 
cephalic cranial proportions, its long-crowned teeth, and especially in the presence of a square upper lip and very large anterior horn and small posterior horn. It is thus distinguished both by the proportions of its horns and by the characters of its teeth and lips from the two species of Dicerorhinus. It is distinctively a grazing animal.

\section{STNONOMY OF RHINOCEROS GENERA}

1. Indian rhinoceros: $R$. indicus $=$ RHINoceros Linnæus 1758

2. Black rhinoceros of Africa: D. bicornis = Drceros Gray 1821

$\because$ Woolly rhinoceros: $R$. antiquitatis (Blumenbach 1799) = CeLodonta Bronn 1831

4. Sumatran rhinoceros: D. sumatrensis = DICERoRHINUs Gloger 1841

5. White rhinoceros of Africa : D. simus = Ceratorhinus Gray 1867

The names of these three rhinoceroses are almost hopelessly confused in the early literature. The animals converge toward each other in sereral characters, namely, in the loss of cutting teeth and in the development of an osseous septum for the support of the nasal bones. The woolly rhinoceros ( $D$. antiquitatis) is first recorded in Europe in deposits correlated with the Third Glacial or Riss Stage, the Mammut Lehm of Cannstatt (Koken, Schmidt, 1912).

Bovines.-The bison (B. priscus) rivalled the mammoth as a wanderer and was able to adapt itself to wide diversities of climate in Europe, Asia and America. Originally of African-Asiatic origin it became thoroughly acclimated as a Eurasiatic meadow and plains type and may have extended also into the forests like the existing woodland bison ( $B$. athabascee) of Canada. It is readily distinguished as brachycephalic while its contemporary, the gigantic urus, is long-headed (dolichocephalic), as well as less agile than the bison. In external appearance, as depicted in the very numerous engravings and paintings in the Font de Gaume and other caverns, this animal resembled the existing American bison (B. americanus) more than the still surviving Lithuanian and Caucasian form ( $B$. bonasus). The animal appears in the First Interglacial, or Torfolkian Stage in France. In the Second long warm Interglacial Stage there existed a bison (B. priscus antiquus) which enjoyed a wide distribution. The animal found its way to the Mediterranean islands and gave rise to the pigmy varieties.

The wild ox (Bos primigenius) also occurs in the First Interglacial Stage and survived the vicissitudes of the entire Pleistocene Epoch. The "urus" of Cæsar survived in its wild state in Europe as late as the seventeenth century A. D., where it was still to be found in the forests of Poland and in a few game preserves. It then disappeared so completely 
that even its popular designation "auerochs" was transferred to the Lithuanian bison. ${ }^{6 \tau}$ The designations of these two types are therefore rery confusing and are distinguished by Kiobelt as follows:

Urus (Pliny).

wiln ox, urochs, atuerochs (Old Ger-

min), tur (Polish). urstier

$=$ Bos primigenius

Bonasus (Aristotle) wisent or wisont, subr (Polish), aner-

ochs (of recent date)

$=$ Bos priscus

The relations of the wild cattle of Asia to domestication will be considered on a later page.

Megaceros giganteus.-During the first half of the Pleistocene this noble animal was widely distributed in Ireland, England, Scotland, the Isle of Man, France, Denmark, Germany, Austria, northern Italy and parts of Eurasia even into Siberia. The famous Megaceros beds of Treland are freshwater clays which frequently underly the peat bogs. As observed by Williams these are "boulder-clays" which were redistributed as lake sediments and accumulated under genial or temperate climatic conditions like the present. Owing to the similarity in the palmation of its antlers the giant deer has been generally (Lydekker, Weber, Trouessart) placed within or very close to the subgenus Dama, the fallow deer; but Lönnberg.68 regards the likeness between the giant deer and fallow deer as convergence and considers that the giant deer is more closely related phylogenetically to the reinteer, but it is nevertheless so specialized as to hold an independent place in the system of Cervidæ. The Megaceros last appears in early Postglacial times associated with the Aurignacean culture in Germany : it is not recorded (Schmidt) with the succeeding Solutrean or Magdalenian culture. It thus became extinct before the close of the Palrolithic.

Elaphine or Red Deer. ${ }^{69}$-Sir Victor Buck held that the Cerrida originated in Asia and from there spread westward into Europe or eastward into America. The Asiatic origin of the red deer race has since been ably maintained by Köppen. A very large race of late Pleistocene times has been compared by Nehring with the $C$. canadensis of North America.

Reindeer.--The reindeer of Pleistocene times are generally referred to the Barren Ground or Tundra type. In this type, which is typified by the existing Old Torld reindeer ( $R$. tarandus, $R$. spitzbergensis) and by the American arctic forms ( $R$. arcticus, $R$. Gronlandicus, $R$. granti, $R$.

${ }^{6 \pi}$ Pohlig, H. : Eiszeit und Yrgeschichte des Menschen. p. 131. Leipzig. 1907.

Rütimerer, L. : "Die Fauna der Pfahlbauten der Schweiz." Neue Denkschr. schweiz. Ges. gesam. Naturwiss., Vol. xix, pp. 68-112. Zürich, 1862.

Koвelt, W.: Die Verbreitung der Tierwelt. 8vo. Leipzig, 1902.

as Lörcerg, E. : "Which is the Taxonomic Position of the Irish Giant Deer and Allied Races?" Ark. Zoöl., Vol. 3, No. 14, pp. 1-8. एpsala, 1906.

${ }^{69}$ ScharfF, R. F.: The History of the European Fauna, pp. 246-251. London. 1999. 
pearyi), the antlers are round. slender and long in proportion to the relatirely small size of the animal, while the spreading beam and brow tines are as a rule but little palmated, although in some forms the brow tine is palmated.

The woodland type, which is now extinct in Europe, is typified by several American species ${ }^{70}$ (R. caribou, R. montanus, R. osborni) in which the antlers are heavier, flatter, thicker, and more heavily palmated on the spreading beam and on the "brow tine" especially, while the tine above the brow, which corresponds to the bez-tine of the stag (Cervus), is elaborately developed and palmated thus contrasting sharply with the simple bez-tine of the Barren Ground group.

Some writers ${ }^{71}$ (Scharff) maintain that the Barren Ground reindeer entered Europe first during the First and Second Glacial Stages while the woodland group first appears in the Third Glacial Stage. Others (Hilzheimer) maintain that all the known Pleistocene reindeer belong to the Tundra form and not to the woodland form. Again, Dietrich ${ }^{\text {i }}$ recognizes a woodland caribou in the "high terrace" gravels of Steinheim in the valley of the Murr.

Carnivores.The larger Pleistocene carnivores embrace the wolves (Canis Tupus), the bears ( $U$. arctos, $I$. spelcea), the hyænas ( $H$. crocuta spetaa, H. (brunnea) striata), the leopards (Felis pardus of Spain) and the lions.

The chief enemies of the wild horses and cattle of the Pleistocene were the lions (Fetis leo spelca), descended either from the great cats of the Pliocene of France and Italy (Felis arvernensis) or more probably migrants from northern Africa. These lions are known from deposits in England, Belgium, Austria, southern Russia, France, Spain, ${ }^{73}$ Italy, Sicily, Greece and Algeria. ${ }^{74}$ The fact that remains of this animal are so often associated with those of the cold Postglacial fauna makes Nehring's ${ }^{75}$ suggestion seem plausible that the cave lion was a northern race of the recent African and western Asiatic lion adapted to a colder climate and with a heavy coat. After examination of specimens from central and northern Europe Boule ${ }^{74}$ reaches the conclusion that these lions

${ }^{70}$ Grayt, Madrsoy : "The Caribou." Ann. Rept. N. Y. Zoöl. Soc., no. 7, pp. 175-196. New York, 1892.

$\pi 1$ op. rit.. p. 154 .

72 Dietrich. W. O.: "Neue fossile Cervidenreste aus Schwaben," Jahreshefte des Vereins f. vaterländische Naturkunde, Jahrg. 66, pp. 320-336. 1910.

${ }^{73}$ HARLE, EDOTARD: "Les mammifères et oiseaux quaternaires connus jusqu'ici en Portugal. Memoires suivi d'nne liste générale de ceux de la Pêninsule Ibérique." Com. mun. du Service géol. du Portugal, T. VIII, pp. 22-85, pll. I-V. 1910.

${ }^{74}$ Bodle, Marcelis : "Les Grands Chats des Cavernes." Ann. de Paléont., Vol. I. pp. 20-27. Jan., 1906.

75 Nenrivs, A.: ¿̈ber Tundren und Steppen der Jetzt-und Forzeit. mit hesonderer Beriicksichtigung ihrer Fauna. Berlin, 1890. 
are not related to the tiger ( $F$. tigris) as was supposed formerly by De Blainville and Lartet. While rich in individual variations Felis leo spelca is nearer the lion than the tiger in most of its characters; it should, in fact, be considered a veritable race of the recent lion with the name Felis leo speloxa. It differs from both the recent lion and tiger in the more gentle and uniform slope of its facial profile and in its large, flat forehead, but its limb bones are longer and proportionately thicker. It sometimes equals and often surpasses the existing lions and tigers in size. It is represented in the cave engravings and drawings both of early and late Postglacial times.

The cave hyæna (Hycena crocuta spelcea) is a variety of the living spotted hyæna (Hyæna crocula) of East Africa, but it attained dimensions considerably greater than that of its living ally. It has the larger proportions, the heavier build, the broad skull, the powerful carnassial teeth which distinguish the spotted from the striped hyæna (H. striata) of the present day. Although proportionately heavier the hind limbs may have been shorter than in the spotted hyæna in adaptation to the cavern life which the inclement climate made necessary. The cave hyæna was a very abundant type and is responsible for scattering of the vast numbers of the bones of the contemporary animals in a manner not pleasing to the palæontologist.

In the caves of southern France a variety (Hycena priscus) of the striped hyæna (Hyæna striata) also occurs and there are also discovered here additional remains of an animal ( $H$. intermedia) resembling the cave hyæna. Thus the Pleistocene species of Furopean hyænas underwent an evolution of their own. As a result the living African forms differ more from the Pleistocene hyænas of Europe than they do from those of Pliocene times.

Harlé $^{76}$ records the striped hyæna (H. striata) as characteristic of the earlier or warm Pleistocene of Spain and Portugal; the cave hyæna ( $H$. crocuta spelca) survived into the late Pleistocene through adaptation to the cold climate.

The cave wolf (Canis lupus speloca), a member of the forest fauna, also attained dimensions greater than its living allies. According to Gaudry and Boule, ${ }^{77}$ (1892) no constant osteological differences can be determined between the Pleistocene cave wolf and the modern wolf of western Europe, although the cave form is of considerably larger size. This animal is represented in the Upper Magdalenian paintings of Font de Gaume.

\footnotetext{
${ }^{76}$ Op. cit., 1910, pp. 46, 70.

${ }^{77}$ GAdDRY, A., and Bodle, M. : Matériaux pour l'Histoire des Temps Quaternaires, Fasc. 4, Les Oubliettes de Gargas. pp. 108-112. Paris, 1892.
} 
Third Glacild Stage-Illinolan. Polandin, Riss

In North America the Third Glacial Stage is heralded by the advance of a great ice cap radiating from Labrador which sent its glaciers to the south and far southwest, depositing the Illinoian drift which is regarded (Leverett, 1910, p. 315) as of an earlier period than the Polandian or "Middle Drift" of northern Germany or the Riss drift of the Alpine region. This Third glaciation of the Alpine region has a period of adrance and retreat which is relatively estimated by Penck at 20,000 years, the snow line descending $1,250 \mathrm{~m}$. With it are associated the "high terrace" deposits of the Alpine region. The Third glaciation was greatly extended along the Rhine, in parts of Switzerland, in France, and in the valley of the Po (Fig. 9). In northern Germany the principal reason for separating the "Middle Drift" (Polandian) from the "Upper Drift" (Mecklenburgian) is the presence of loess deposits between them which seems to strengthen the evidence for a Third Interglacial interval. 'These loess deposits are regarded by certain German geologists (Koken) as the continuation of the "Older Loess" but by Penck and Leverett they have been regarded as belonging to the "Newer Loess."

\section{THIRD GLACIAL FAUNA}

The recurrence of a cold climate in Germany is heralded in the Upper Sands of Mauer by the arrival of the reindeer and other arctic types. In the Mammut Lehm of Cannstatt is found a fauna which is regarded by Koken and Schmidt (1912, op. cit.) as contemporaneous with the Third Glacial advance. It is noteworthy as containing two new arrivals from the tundras of the north, namely, the woolly mammoth (E. primigenius) and woolly rhinoceros (D. antiquitatis), as well as the reindeer ( $R$. tarandus). The other members of this fauna include two species of horse, the giant deer, the stag, the bison and the urus. "Cannstatt," observes Schmidt (1912, p. 270), "affords a geological and final connecting link between the Second Interglacial fauna of Mauer and the fauna of Early Palæolithic [or Third Interglacial] times." If this fauna actually entered Germany during the cold period of the Third glaciation it returned to the north with the approach of the warm-temperate climate of the Third Interglacial Stage, because no trace of it is found until near the close of the Third Interglacial Stage.

\section{Third Interglaciat Stage-Riss-Würm, Sangamon}

The Third Interglacial Stage is shorter than the Second, its geologic and faunal characters are more fully known, and it embraces the first 
undoubted remains of human stone industry in Europe as well as abundant remains of man. In the Alpine region this Riss-Würm Stage is indicated by "high terraces," which rise 25 to $50 \mathrm{~m}$. above the existing streams. The Riss-Würm interval is evidently shorter than that between the Second and Third glaciation. Penck considers that the depositions of "Newer Loess" which occurred in the Alps near the close of Riss-Wïrm Interglacial times represent a cold stage, since the fauna which it contains is of the Tundra-Alpine type and the Palæolithic implements found in it are closely similar in workmanship to those found in deposits subsequent to the Trürm glaciation (Penck, 1909, p. 1159). He regards this as the "Newer Loess" that was laid down prior to the Fourth glaciation. Koken and Schmidt, on the other hand (1912), regard the "Newer Loess" as partly or wholly Postglacial, that is, as occurring after the Würm maximum. The Third Interglacial loess of northwestern Europe was comparatively scanty and discontinuous, from 1 to $5 \mathrm{~m}$. in thickness, and contains a terrestrial molluscan fauna as in America. All the indications are that this loess was deposited by prevailing westerly winds. Also along the Danube the loess is chiefly due to westerly winds. Penck attributes the scarcity of loess in the southern, eastern and western borders of the Alps to the presence of thick regetation even during the glacial stages, the moraines being pushed out into the forests.

Tn America the Third Interglacial interval is known as the Sangamon: the deposits are composed of dark, black soil which is overlain by the main or thickest loess deposit of the central United States. There appears to have been a long interval between the melting of the Third Glacial ice and the deposition of the loess which contains a terrestrial molluscan temperate fauna, indicating climatic conditions not greatly different from those now existing in the same regions (Shimek, 1909).

The geologic deposits of this stage are mainly of three kinds: first, fluviatile sands and gravels: second, loess; third, hearth or kitchen-midden deposits made by man toward the cold closing period of this stage.

\section{CLIMATIC CHANGES DURTNG THE THIRD INTERGLACIAL STAGE}

The Third Interglacial Stage opens with a renewal or continuation of climatic conditions favorable to an Asiatic-African fauna exactly similar to that of the warm Second Interglacial period. This warm fauna is known as the "Second $E$. antiquus fauna." It includes the hippopotamus, the straight-tusked elephant (E. antiquus) and the southern elephant (E. trogontherii). This last species is even referred to by many writers as E. meridionatis. 
This is the Elephas antiquus Stage of Pohlig, this animal being very abundant until toward the close of the Third Interglacial Stage when it makes its last appearance in Europe. The broad-nosed rhinoceros ( $D$. merchii) is also abundant and appears in Europe for the last time.

The successive climatic phases of mammalian life are most clearly recorded in connection with the culture stages of the Lower Palæolithic period, including the pre-Chellean, Chellean, Acheulean, and the beginning of the Mousterian cultures. As indicated on p. 233, the warm Asiatic-African fauna prevails from the pre-Chellean until toward the close of Acheulean times, when there is evidence of the advent of a cold dry continental climate, on the approach of which the hippopotamus, Elephas antiquus, and Dicerorhinus merckii gradually retreat. Thus at Tillejuif. south of Paris, the late Acheulean implements are found imbedded in great drifts of loess, a proof that a cooler, drier climate which marks the transition from the last warm Interglacial Stage to the Fourth Glacial adrance was prevalent. Chiefly in the southern parts of France we find the Elephas antiquus fauna still persisting until the close of the Third Interglacial Stage or during the early Mousterian period, a sign that this old African-Asiatic stock did not become extinct but migrated from central Europe to warmer regions in the south and southwest.

Flora.-Indications of changes of climate in the Third Interglacial interval are preserved in the tuf de la Celle-sous Moret (Seine-etMarne) ${ }^{78}$ which overlies Pleistocene river gravels near Paris. The lower levels contain the sycamore maple (Acer pseudoplatanus), willows (Salix). the Austrian pine (Pinus laricia). Higher up in the same deposits we find the box tree (Buxus) and not uncommonly the fig (Ficus); the canary laurel (Laurus nobitis) occurs less frequently; the canary laurel and the fig indicate that the winters were mild because both these plants flower during the winter season. The climate was more damp and somewhat milder than that of the present time in this region. The Mollusca of the tufa of La Celle also indicate that the climate of northern France was more equable so as to permit species now widely separated to live together. The plants in the highest levels of the tufa, however, indicate a cooler climate and vield Acheulean flints. The tufa is itself covered by a sheet of loess corresponding to the return of a cool, arid period in late Acheulean times.

In Lorraine below the level of the fauna of the Fourth glaciation there occurs a flora in which the most northerly varieties of the larch (Larix) and the monntain pine (Pimus lambertiana) predominate. The lignites of Dürnten and of Ttznach near Zürich (Fig. 9, 18) contain fossil re-

78 HACG, op. cit., 1908-11, p. 1812. 
mains of forests of Third Interglacial age similar to those which still flourish in the same region, consisting of spruce, fir, mountain pine, larch, birches, yews and sycamores with undergrowth of hazel. These lignitic deposits rest upon the remains of a retreating glacier and are in turn covered with those of another glacier and are therefore interglacial. ${ }^{79}$ With this hardy flora are associated remains of Elephas antiquus, D. merckii, the urus and the stag.

Fauna.-The mammalian fauna is broadly divided into: first, the warm African-Asiatic, which disappears from Europe at the close of the Third Interglacial Stage; second, the Eurasiatic Forest Fauna, in which we now include the urus ( $B$. primigenius) and the bison ( $B$. priscus): third, the Tundra Fauna, which retreats after the Third Glacial Stage to reappear with the approach of the Fourth Glacial Stage, when the full tide of Tundra life, including fifteen species of mammals and birds, and the advance wave of Steppe life, including nine species of mammals and birds, first arrive in Europe. The chief localities in which the fauna is recorded are the following:

Warm Stage. Chelles, ${ }^{80}$ St. Acheul, valley of the Somme, northern France. Warm Fauna.

Grays Thurrock and Ilford, Essex, England. Warm Fauna.

Cool Stage. Taubach-Weimar-Ehringsdore-Achenheim, Germany. Acheulean stage. Temperate Fauna.

DỨRnten, UtzNACH, near Zürich, Switzerland (cool flora, fauna).

Laviste, Argelades, travertines, Marseilles, France (flora).

Krapina (cavern of), Croatia (fauna and human remains).

Cold Stage. Rixdorf, near Berlin. Cold fauna.

\section{PILTDOWN MAN, EOANTHROPUS DAWSONI}

Fragments of a skull and jaws discovered by Dawson in 1911 near Piltdown, Sussex, have been described by Dawson and Smith Woodward. ${ }^{81}$ They were associated in a fluviatile sand layer with a single pre-Chellean flint and remains of deer (? deer), rhinoceros (D. etruscus or D. merckii), beaver (Castor fiber), and hippopotamus. The geologic age is not positively determined by the fauna nor by the nature of the river gravel deposits in which these specimens were found. The associa-

${ }^{70}$ Dawkrns, W. B. : "Classification of the Tertiars Period by Means of the Mammalla." Quart. Jour. Geol. Soc., Vol, xxxi, pp. 379-405. Aug., 1880.

80 The Chellean culture is placed by Penck and Geikie in the Second Interglacial Stage.

81 Dawson, CH., Smith-Woodward, A., Smith, G. Elliot: "On the Discovery of a Palæolithic Human Skull and Mandible in a Flint-bearing Gravel Overlying the Wealden (Hastings Beds) at Piltdown, Fletching (Sussex). With an Appendix by Prof. Grafton Elliot Smith." Quar. Jour. Geol. Soc., Vol. 69, pp. 117-151, Pls, XT-XXT. London. 1913. 
tion of the pre-Chellean flint and of numerous Chellean flints in the overlying layer would tend to determine the age as either Third Interglacial or at the earliest Second Interglacial.

The placing of the skull and jaws together as belonging to one individual is not certain, but is highly probable. The cranial bones are extremely thick; the skull is not Neanderthaloid, but is of a high, dolichocephalic type, with a brain capacity variously estimated at $1,100 \mathrm{ccm}$. (Elliot Smith, 1913) to 1,500ccm. (Keith, 1913). ${ }^{81 a}$ The jaw resembles closely that of an orang (Simia satyrus); the two lower molar teeth preserred are more elongated than in any human type; the superior canine tooth (mistaken by the authors for an inferior canine) resembles that of the anthropoid ape. Thus the specimen may be concisely described as possessing the skull of a man combined with the jaw and the dentition of one of the higher anthropoid apes. A number of eoliths and one palæolith were also found in the same layer with the skull.

\section{PRE-CHELLEAN AND CHELLEAN FAUNA}

The dawn of the stone industry in Europe is known as the pre-Chellean. It is found at Chelles in France, in Spain and at Piltdown, Essex, England. It is important to note that the Chellean culture stage is regarded by Penck, Geikie and others as belonging to Second Interglacial times, or the Mindel-Riss, while Boule, Haug, Obermaier, Breuil and Schmidt assign the pre-Chellean-Chellean culture to the Third Interglacial Stage. While the latter opinion generally prevails among archæologists there is reason for further investigation before the geologic age of the pre-Chellean and Chellean cultures can be considered as definitely determined.

The faunal period of the Chellean culture proper is shown in the valleys of the Somme and of the Marne where mingled with the Pre-Chellean and Chellean flints are found the hippopotamus, the southern elephant (E. meridionalis trogontherii) with the straight-tusked elephant ( $E$. antiquis) and the broad-nosed rhinoceros (D. merckii). The typical site of the Chellean culture stage is near the town of Chelles in the wide expanse of the Marne valley. The river deposits of the period of the Chellean culture in this valley are eight meters in thickness and contain beside the animals named above the giant beaver (Trogontherium), species of bear, of hyæna, various kinds of deer, larger and smaller kints of wild cattle and a primitive wild horse.

At Abbeville, at the mouth of the Somme, are found remains of the

${ }^{81} a$ The corrected and final determination is at $1,300 \mathrm{ccm}$., Smith-Woodward, McGregor, 
same animals associated with those identified as belonging to the sabretooth tiger (Machurochs).

Chellean Culture on the "Low Terraces." - It appears that the Chellean culture stage in many regions was subsequent to the formation of the terraces; thus Chellean flints may occur in the superficial gravels both on the "middle" and on the "low terraces." Haug (1912) supports the theory that the Chellean culture belongs to the Third Interglacial Stage. This accords with the terrace chronology. The minute researches of Iaville in the basin of Paris are confirmed by the observations of Commont in the valley of the Somme. Along the Somme Chellean flints occur in the deep gravels overlying the middle and upper terraces. The fauna found in the "low terraces" of Chelles and of Grenelle is the same, namely, E. trogontherii, Trogontherium cuvieri, Hyana crocuta, D. merchii, Hippopotamus major, Elephas antiquus. All these animals found at Chelles occur in the gravels a few meters above the level of the Marne; they belong exclusively to the sands and gravels at the base of the diggings in the "low terrace." Similarly in the valley of the Somme near Abbeville from the base of the "low terrace" are recorded Acheulean flints with H. major, D. merckii, Elephas antiquus, etc. Laville collected at Arceuil in the valley of the Biève, in gravels assigned to the "low terrace," Chellean, Acheulean and Mousterian flints; these "low terraces" are only $5 \mathrm{~m}$. above the river level and are still occasionally flooded with the high waters of the Seine. It is hardly probable that the close geologic and faunistic association of the ChelleanAcheulean cultures in these "low terraces" could have been separated by a very long geologic period, amounting to a hundred thousand years, as demanded by the theory of Penck.

What is regarded as the rypical Third Interglacial fauna of the more northern regions of Europe as found at Grays Thurrock, Ilford (Essex, England) and at Taubach is as follows:

Straight-tusked elephant, Elephas antiquus

Southeru mammoth, E. trogontherit

Broad-nosed rhinoceros, D. merckii

Hippopotamus, H. major

Wild horse, E. ? caballus (probably

the Forest variety)

Wild boar, sus scrofa ferus

Bison, Bison priscus

Urus, Bos primigenius

Red deer, Cervus elaphus

Roe deer, C. capreolus
Grays Thurroct, Ilford (Essex, England). - The hippopotamus is here recorded by Dawkins. The elephant of Fssex is referred by Pohlig to $E$. trogontherii. The horse (Errart) is considered to belong to the Forest or Nordic type. This Essex fauna is characteristic of the river shores and of the neighboring forests and meadows. The lions, hyænas and hears which are re- 
Giant deer, Megaceros

Hyaena, H. crocuta spelaa

Brown bear, Trsus arctos

IVild goat, Capra

Lion, Felis leo antiqua

Wolf. Canis sucssi

Badger. Meles taxus

Marten, Mustela martes

Otter, Lutra vulgaris

Bearer, Castor fiber.

Hamster, Cricetus vulyaris

The water role, Arvicola amphibius corded here are not true cave types, but are in part ancestors of the cave types which appear in the succeeding reindeer or cavern period.

\section{ACHEULEAN CULTERE FATX'A}

Warm Stage.-The early Acheulean culture as found at Taubach, Weimar, Ehringsdorf and Achenheim contains the hippopotamus and the straight-tusked elephant ( $E$. antiquus). The principal feature of the earIy Acheulean culture stage seems to be the abundance of these AfricanAsiatic animals so that this is commonly known as the "warm Acheulean" fauna.

Cool Stage.-The Acheulean culture endured for a long period of time and toward its close two typical members of the warm fauna, namely, the hippopotamus and E. trogontherii, disappear. Thus the late Acheulcan fauna does not include either hippopotamus or $E$. trogontherii but there still survive the $E$. antiquus and the broad-nosed rhinoceros ( $D$. merchii). These animals persisted in Europe for a considerable time and becoming adapted to a colder climate are sometimes found in association with the advent of the true mammoth (E. primigenius) and the woolly rhinoceros (D. antiquitatis).

During late Acheulean times a dry, cool continental climate prevailed (Hilzheimer, 1913, p. 145) similar to that of the steppes of southern Russia between the Ural Mountains and the Caspian Sea. Evidences of this are observed even in the sheltered valley of the Vézère, a tributary of the Dordogne in southwestern France. Similarly as regards northcentral France, Obermaier (1912, pp. 122-124) observes that while the climate was mild and temperate and the country still forested at the beginning of the Acheulean culture, in late Acheulean times the implements at Tillejeuf south of Paris, are found embedied in drifts of loess. a proof that the colder climate which marks the transition from the Third Interglacial Stage to the Fourth Glacial Stage was now beginning to prevail. The fauna is still that of $E$. antiquus and $D$. merchii. More rarely (Schmidt, 1912) Achenlean palæoliths are associated even with remains 
of the woolly mammoth and the woolly rhinoceros, indicating that in northern localities the Acheulean culture reached the cold period of the Fourth Glacial Stage.

Krapina Neanderthaloid Race.-To the Acheulean Stage there is referred a human tooth found at Taubach. Of much greater importance is the presence of abundant skeletal remains of men of a primitive Neanderthaloid race found in the cave-shelter of Krapina in Croatia. These remains are positively associated with the Acheulean stage by Schmidt. (1912, p. 256) but they are regarded as more recent, of the late Mousterian culture stage, by Breuil. The remains as finally described by Gorjanovic-Kramberger ${ }^{82}$ include hundreds of human bones intermingled in various separate strata with hundreds of stone implements and chips and thousands of animal bones. Of the contemporary fauna are recorded Ursus spelous, Bos primigenius, Equus ? caballus, Dicerorhinus merckii, Megaceros euryceros, Castor fiber, Arctomys marmotta. The human racial type is unquestionably related to that found at Neanderthal and Spy. The race is somewhat dwarfed, of broader head form, with less prominent supraorbital processes. The species is Homo neanderthalensis.

Mousterian Culture, Temperate Fauna.-The earliest strata of the Mousterian culture stage in France show a fauna not differing essentially from that of the late Acheulean stage, namely, a fauna containing Elephas antiquus and Dicerorhinus merckii. Thus in La Micoque, one of the oldest stations in the Vézère valley, Dordogne, in which the culture belongs to the transition between late Acheulean and early Mousterian times, in the very lowest layers are found traces of the broadnosed rhinoceros (D. merchii) associated with remains of the moose (Alces). But the last glacial stage is approaching and $D$. merckii gives place to the migrants from the tundra region of the northeast, covered with hair, adapted to an arctic climate, namely, the mammoth and the woolly rhinoceros. The main succeeding portion of the Mousterian culture was contemporaneous with the Fourth Glacial Stage and the cold tundra, steppe fauna.

\footnotetext{
82 GorJanovic-KraMberger, KarL: "Der Diluviale Mensch von Krapina in Kroatien Ein Beitrag "ur Palänanthropologie. Studien iber die Entwickelungsmechannik des Primatenskelettes mit besonderer Berïcksichtigung del Anthropologie und Descendenzlehre." Herausgegeben von Dr. Otto Walkhoff. C. W. Kreidel's Terlag, 4to. Wiesbaden, 1906.
} 


\section{Focrth Glacial Stage- Müpar, Mechlenbutian, Wisconsin}

\section{BEGINNING OF THE REINDEER AND CAVE PERIOD}

The Fourth Glacial Stage, like the First, is believed to have been nearly contemporaneous in Europe and North America, consequently the estimates of Postglacial time in one country have an important bearing on the other. The First Maximum of the Fourth or Wïrm glaciation in the Alps is estimated by Penck as occurring 40,000 years ago. It was followed by the slight recession known as the Laufenschwänkung, a temperate retreat followed in turn by the Second Würm Maximum, which is estimated as occurring 20,000 years ago. Similarly in America the "early Wisconsin" is followed by a recession interval (Peorian), and this in turn by the "late Wisconsin" which is the final great glaciation in America. The contemporaneous Mecklenburgian of the North German lowlands gave rise to the "Upper Drift," which in some respects bears a striking resemblance to the Wisconsin Drift of America both in its systems of moraines and in its topography. This stage also includes apparently the "Upper Drift" of northern England with which the drift of the Alps correlates well. The Upper Drift of England covered also a large part of Wales. In Germany glaciation also occurred in the Riesengebirge and the Black Forest.

In America part of the "Upper Drift" is loess-covered and in the opinion of Koken and Schmidt the Upper Drift of Germany is also partly covered with the "Newer Loess." The Postglacial Stage did not exhibit a steady amelioration of climate after the culmination of the Fourth Glacial Stage, but there is evidence of great oscillations and renewed glacial advances both in northern Britain and Scandinavia and in Germany. These Postglacial advances, as most clearly defined in the Alpine region, have been termed by Penck the Bühl, the Gschnitz and the Daun. They are correlated by palæontologists and anthropologists quite closely with the successive faunæ and archæological implements of Postglacial time.

Period of the Final Glacial Maximum.-The length of time which has elapsed since the close of the Fourth great glacial advance is estimated in America by the recession of the Falls of Niagara. This recession began with the end of the Wisconsin glaciation which is believed to have been contemporaneous with the Würm. As early as 1829 Bakewell estimated that since the Falls of Niagara were receding by the erosion of the Niagara gorge at the rate of three feet annually about 10,000 years had elapsed since the end of the Glacial Epoch. Lyell visited Niagara in $18+1$ and after consideration of all the data of erosion concluded that 
the time since the last great glacial stage was not less than 31,000 years. Gilbert, Upham and other geologists of the United States Geological Survey after pointing out many sources of error in all such calculations were inclined to the adoption of periods ranging from 6,000 to 10,000 vears. Gilbert's survey is the most careful which has been made; he estimated (1896) that the gorge of Niagara is not more than $\%, 000$ years of age. The Canadian geologist Spencer arrived at a result almost identical with that of Iyell, namely, 32,000 years.

The most careful estimates on the subdivisions of Postg]acial time in Europe are those of Penck (1909, p. 1168) which may be briefly summarized as follows:

IV. 2nd WÜ̉M Iraxmmus, beginning of Upper Palæo-

lithic culture...................20,000 to 34,000 years

Achen retreat, period of Aurignacean and Solutrean

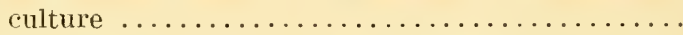

Bühl advance, period of early Magdalenian culture (Neüsch) . . . . . . . . .

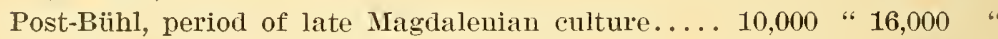

Daun Stage, period of the close of the Upper I'alieo-

lithic, Azilian culture................. 7,000 "

Age of Copper in Europe................

According to Heim's ${ }^{53}$ calculations the period since the deposition of the Buihl moraines in the Lake of Lucerne amounts approximately to 16,000 years and if the Magdalenian culture deposits of this formation are of the age of the Bühl advance we may estimate with Neüsch that the Bühl advance occurred at least 24,000 years ago. This adrance is a very important period because it represents the last of the Arctic, Tundra and Steppe Faunas in central Europe prior to the establishment of the modern forested conditions and fauna.

Fauna of the Fourth Glacial Stage.-The severe climate of the Fourth Glacial Stage is indicated by the mammalian life found at Achenheim and Sirgenstein associated with what is known as the "full Mousterian" Palæolithic culture (Schmidt, 1912). Here for the first time there is a predominance of the Tundra Fauna (fifteen species) as well as the advent of the Steppe Fauna (two species), while the Forest Fauna (seven species) and Meadow Fauna (four species) are still represented. The straight-tusked elephant (E. antiquus) and broad-nosed rhinoceros ( $D$. merckii) have disappeared and are now replaced by the woolly elephant (E. primigenius) and woolly rhinoceros (D. antiquitatis). The mam-

\footnotetext{
83 Herm, A. : "Ưber das absolute Alter der Eiszeit." Vierteljahrsschrift der natur-
} Eorsch. Ges. in Zürich. Jahrg. 39. No. 2, pp. 180-186. 1894. 
mal life of the Fourth Glacial Stage at Achenheim and Sirgenstein near the upper Rhine is divided among the various faunæ as follows:

TUXDRA

Elemhes primigenius

Diceros antiquitatis

Ranlifer tarandus

Tulpes lagopus

Le'plus rariatilis

Hunorles torquatus

STEPPE

Equus germanicus (Steppe type)

spermophilus rufescens.

FOREST

Cereus claphus

Lymirli us lynix

Canis lupu.s

Tulpes alopex

Arvicola amphibins

Ursus speleus

ALPLNE:

Aretomys marmotta

Ibex: sp.:

Lagopus alpinus.

MEADow

Bison priscus

Bos primigenins.

As:ATIC

Hycua spelea

Felis leo spetca

This "Tower Rodent" stratum with a fauna such as we find at present in far northern Russia registers the coldest climate of Pleistocene times, corresponding to the Second Maximum of the Fourth Glacial Stage. It is well known that this Lower Rodent fauna is not local but rather a widespread phenomenon extending over northern and southern Germany and Belgimm (Nchmidt, 1912, p. 261). The presence of this Lower Rodent fauna at Thiede near Braunschweig in the border region of the Upper Glacial Drift of Germany is of special significance, as Wahnschaffe observes. This is the classical locality for lemming, the remains of lemmings being associated solely with those of arctic fox, arctic hare. reindeer, musk ox and mammoth.
After the First Maximum of the Fourth glaciation the Laufenschwänkung may have temporarily favored the return of the Elephas antiquus and $D$. merckii fauna as far as northern France because we occasionally find a glacial mixed fauna where $E$. antiquus and $D$. merckii occur in association with $E$. primigenius. 'The close of the Fourth Glacial Stage or Second ITürm Maximum is marked by the first appearance of very numerous arctic rodents, especially of the banded lemming (Myodes torquatus) type, which constitute the socalled "Lower Rodent" layer. The animals (Schmidt, 1912) characteristic of this Lower Rodent stratum as found at Sirgenstein, Wildscheuer and Ofnet are as follows:

TUNDRA

Canis lagopus

Fotorius erminea

Lepus variabilis

Ilyodes obensis

" torquatus

Lagopus albus

FOREST

Arvicola amphibilus.

MEADOW

Talpa europaa 
Upper Sands of Mauer.--In the Upper Sands of Mauer, Wurm (op. cit. 1913) and Förster ${ }^{84}$ have observed the presence of a sub-Arctic cold fauna including the arctic reindeer $(R$. tarandus) and the banded lemming (Myodes torquatus), the steppe suslik (Spermophitus rufescens), also the steppe weasel (Fotorius eversmanni). 'This is positively correlated with the fourth glaciation by Wurm.

The fauna of the Wildkirchli cave on Mont Centis in Switzerland shows no typical interglacial forms and may indicate either the approach of the Würm Glacial period or its Laufenschwänkung (Schmidt, 1912, p. 193).

Mousterian Palcolithic Culture.-The Mousterian Palaolithic culture of the Neanderthaloid race appears to have begun toward the close of the Third Interglacial Stage and continued throughout the entire period of the Fourth Glacial, including the First Maximum, the Laufenschwänkung, and the Second Maximum, ending with the "Lower Rodent" fauna in the deposits of the "Newer Loess." Thus Koken and Schmidt speak of the Mousterian culture as found at the base of the "Younger Loess."

The early men of the Mousterian culture period witnessed in the north the Elephas antiquus and broad-nosed rhinoceros, and the hippopotamus in the south, as proven in the Prince's Cave of Monaco. The culture lasted through all the severe climatic conditions of the entire Fourth Glacial Stage. The men of the Neanderthal race in Mousterian times sought the rock shelters and grottos or entrances to caverns so that the greater number of palæoliths are found mingled with the remains of animals of the chase around the old hearths. The commonest game evidently consisted of the wild horse, urus and reindeer. Less frequently the ibex and stag were objects of the chase.

Neanderthal Races.-To the Neanderthal race (Homo neanderthalensis, ${ }^{85}$ ) in addition to the remains of Krapina, belong many and widely distributed remains, including the classic type of Neanderthal discovered in 1856, the Gibraltar skull discovered in 1848, those of La Naulette, Spy (188\%), Krapina (1902), Malarnaud, La Quina, Le Moustier (1908) and La Ferrassie. The skull of Neanderthal man was character-

\footnotetext{
${ }^{84}$ Förster, F.: "Über eine điluviale subarktische Steppenfauna aus den Sandhügeln von Mauer." Verhandl. naturw. Verein. Karlsruhe, 1913.

${ }_{55}$ The mid-Pleistocene man was definitely named Homo neanderthalensis by Cope in 1893 at the time of the discovery of the skeletons of Spy; it seems, however, that King had previously (1864) used the same term. Schwalbe (1901) remarks, . . . "the species of man which I, together with King (1864) and Cope (1893), designated as Homo neanderthalensis." In the following year (1902) the same author introduces the term Homo primigenius, which is that generally adopted in Germany. Among French authors the same man is known to-day as Homo mousteriensis. This polynomial usage serves at least to emphasize the unanimous opinion as to the distinct specific character of mid-Pleistocene man.
} 
ized ly an extremely receding forehead, by the great prominence of the supraorhital ridges, and by a rather slender jaw. The occipital projection for the attachment of the superior muscles of the neck was large, indicating that these muscles at the back of the neck were strongly developed. a character necessary to meat-eaters before the invention of knives

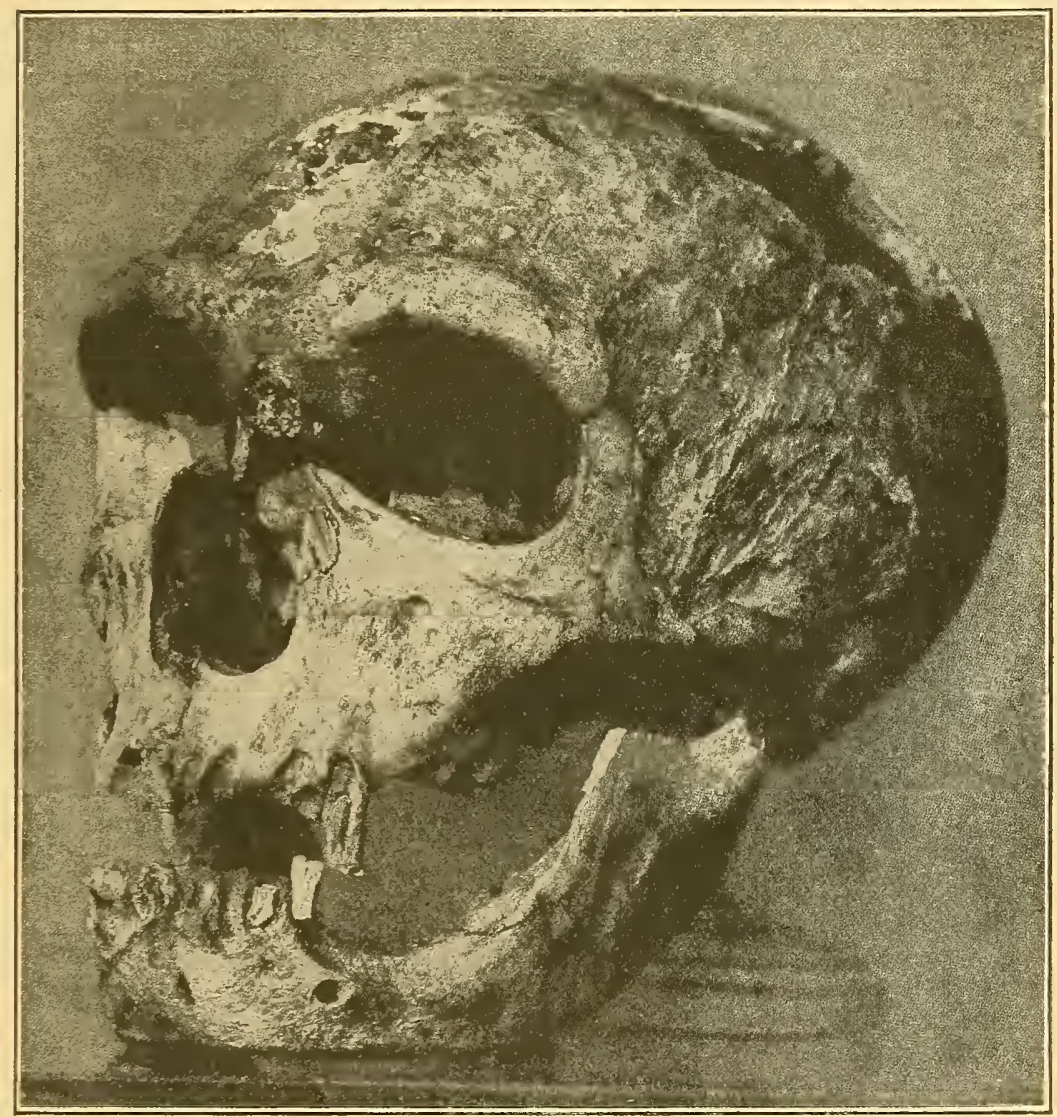

Fis. 16.-Leanderthat skull

Skull of a Neanderthal man from the cavern of La Chapelle-aux-Saints (Corrèze), France. After Boule.

and forks. This primitive type of man was shorter than the average European (that is, 5 feet $81 / 2$ inches); he is estimated of as low stature as 5 feet $31 \%$ inches. His lower limbs were especially powerful, but his sait seems not to bave been fully erect, for the knees are bent slightly formari?. 
The most remarkable skull and skeleton of Mousterian age is that (Fig. 16) found by the Abbés J. and A. Bouyssonie and L. Barton in the cavern of La Cliapelle-aux-Saints (Corrèze) in 1908, associated with stone implements and remains of the reindeer, nrus, ibex and woolly rhinoceros. The cranium is dolichncephalic. with prominent supra-

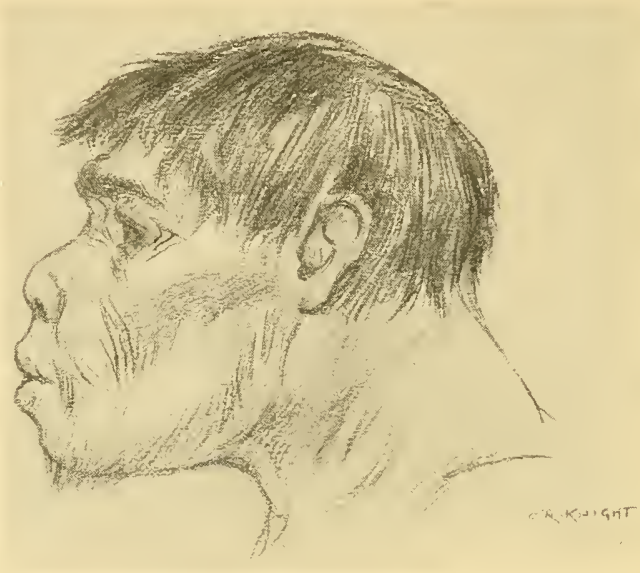

FIG. 17.--Neanterthul intu

Reconstruction of the head of Homo nearierthalensis by charles Ii linight under the direction of the author. 1910.

orbital processes and relatively short and hroad nose. weak lower jaw, lacking the prominent chin process. These characters, as well as the posterior position of the foramen magnum and the form of the palate, are distinctly simian or pro-human. ${ }^{86}$

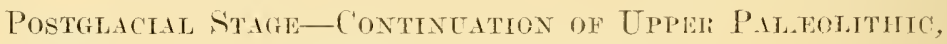 Reindeer or Cave Period}

\section{('LIMLITE}

For a long period the fauna of Postglacial time in Europe remained practically the same, namely, during the Mousterian, Aurignacian, Solutrean and Magdalenian culture periods. The cold fauna is shown both in the animal remains and in the art. which is so characteristic of durignacian and Magdalenian times.

As the "Lower Rodent" layer of Mousterian times is referrer to the Second Maximum of the Fourth glaciation and the period of nost intense

s6 Boute. M. : "L'Homme Fussile de la chanelle-anx-Saints." LiAnthropol.. Vol. XIX, pp. 519-5.5. 1909. 
cold it is followed by an amelioration of climate (Achenschwänkung) during Aurignacian and Solutrean times, which in turn is succeeded by a recurrence of a colder climate during the Bühl advance, at which stage it is believed the "Tpper Rodent" laver of Magdalenian times indicates a fresh inrasion of Arctic-Tundra types. This tundra "Upper Rodent" layer eccurs in the deposits of Sirgenstein. Wildsheuer and ofnet; it is associated along the upper valley of the Damube with early Magdalenian palreoliths, and continues in Iohlefels, Schussenquelle, Andernach, Münzingen and Tildschener in association with the Middle Magdalenian culture stage: there is, moreorer, in Hohlefels. Schmiechenfels and Propstfels an association of the cold steppe fauna with a late Magdalenian culture stage. After this there was a deciderl amelioration of climate, for in the final Azilian-Tardenoisian stage all the Steppe, Tundra and Alpine types disappear.

TPPER PIL.EOLITIIC, FOUli OR FIVE HUMAN RACE

(1) The Frimaldi Race, a negroid type is found close to the warm fanmal level at Mentone. (2) An initial feature of the long Postglacial Stage is the entire disappearance of the Neanderthal race of men and the inrasion of Europe by a new race of the much higher Crô-Magnon type referred to the existing human species (Homo sapiens). This race was discorered in Dordogne at the hamlet of Crô-Magnon from which it takes its name. It has also been found in the cavelns near Mentone lying above remains of the Grimaldi race. Crô-Magnon remains are also found at sereral localities in France in deposits of Aurignacian and Magdalenian times. In the south in Aurignacian times this mas a tall. Well-proportioned. hunting and nomadic race: in the more serere climate of the north it occurs as a dwarfed race. The skulls are dolichocephalic, with rery broad cheek bones, hence designated as disharmonic. The brain capacity is equal to that of the early Neolithic races and surpasses that of many modern races. It is probable but not positirely demonstrated that to this Crô-Magnon race we owe the early arts of engraring, sculpture, design and mural painting which are preserved in the Aurigmacian and Magdalenian deposits of France and northern Spain. (3) In Solutrean times there was at Brünn and Prédmost (Moravia) another dolichocephalic race which is considered as distinct or transitional because unlike the typical Crô-Magnon race the cheek bones are narrow and the skull is thus harmonic. This is the Brïnn-Prédmost race. (4) After the close of the Magdalenian culture stage, or during the so-called Azilian-Tardenoisian culture, the first brachycephalic human races make their appearance in Europe. Their remains have been 
found at Ofnet, Furfooz and at Grenelle. This is commonly known as the Grenelle or Furfooz race; it is very distinct from the preceding races in bodily structure and in culture.

Aurignacian, First Upper Palreolithic Culture Stage.-This first of the Upper Palæolithic culture stages is widely distributed in western Europe. It takes its name from the small grotto of Aurignac (Haute Garonne) where the first discoveries of the culture and of a number of skeletons were made in 1852. The arts of engraving on bone and stone, of drawing and painting in single lines, of sculpture of the human and of animal figures, all in bold but primitive forms, first appear in Aurignacian times. Thus man through his art begins to make a permanent record of the contemporary mammalian life. especially of the mammoth. bison, reindeer and cave bear. With early Aurignacian times the cold climax is passed but we still find remains of the Arctic lemming (Myodes torquatus) fauna. The mammalian list of the Aurignacian stations both of the "Newer Loess" and of the caverns still gives a cold aspect with its Tundra-Steppe-Alpine types with which no warmer types are associated. In middle and late Aurignacian times the lemmings for a time disappear; otherwise the fauna retains its northern character (Gulo luscus, Lagopus alpinus), which is not essentially altered by the presence of the hyæna and stag.

Solutrean, Second Culture Stage.-This stage, which takes its name from the type station of Solutré (Saône-et-Loire) represents the climax of perfection in the Upper Palæolithic flint industry, which appears to represent partly a development of Aurignacian workmanship and partly a culture invasion. With Solutrean times Schmidt correlates the three Brünn skeletons and Prědmost (Moravia). It is noteworthy that no evidences of a Solutrean art have been discovered. The fauna like that of the Aurignacian represents an amelioration of the extreme cold of the Fourth Glacial maximum. The wild horse and reindeer are abundant as well as the mammoth, rhinoceros, wolf and cave bear. Perhaps the somewhat more frequent appearance of such cold faunal types as the Alpine hare and grouse betoken the approach of the colder Bïhl stage of Magdalenian times.

Magdalenian, Third Culture Stage and Fauna.-This third Upper Palrolithic culture takes its name from the station of La Madeleine (Dordogne). It is distinguished by decline in the perfection of the flint industry as compared with the Solutrean stage, by a very decided development of bone implements, and by a surprising advance in the arts of engraving and painting and the sculpture of animal forms in bone and ivory. The Magdalenian stage corresponds with the "Upper Rodent" 
strata which registers a period of extreme cold correlated with the Bühl glaciation (Penck, Schmidt), which again attracts the cold-loving rodents. The "Upper Rodent" strata associated with Magdalenian cultures in the shelters of Schweizersbild and Kesslerloch are of more recent date than the neighboring "Lower Terraces." This "Upper Rodent" stratum contains an abundance of Tundra and Steppe types of smaller rodents and represents the last stage of extreme cold in Europe. Thus the banded lemming (Myodes torquatus) corresponds with early Magdalenian times. In the upper levels of the Upper Rodent layer, which belong to late Magdalenian times, the Tundra fauna gradually gives way to a more abundant Steppe fauna, the banded lemmings becoming less frequent while the jerboas (Alactaga jaculus), the hamsters (Cricetus phcus). the susliks (Spermophitus rufescens) become more abundant. The reindeer and the wild horse are very abundant. 'The mammoth, the woolly rhinoceros and the care bear gradually retire from the middle and southern mountains of Germany, and in the very highest Magdalenian culture larers the fauna begins to approach that of recent times, namely, the Eurasiatic Forest fauna. In Schmidt's opinion there is no question as to the similarity of age of the Magdalenian layers of the Miinzingen loess deposits with the cave deposits of Schweizersbild and Thaingen From this evidence it can be positively determined that the chief deposits of the "Newer Loess" occurred after the Fourth glaciation.

With Magdalenian times are associated the skeletons of La Madeleine, Laugerie Basse, Chancelade, La Hôteaux and Duruthy; all are regarded as of the Crô-Magnon racial type.

\section{POSTGI ACIAL FAUNA}

-The mammal falna of this long Postglacial period is the same in the upper ralleys of the Rhine, the Danube, the Dordogne and the Garonne. It extends throughout the Pyrenees and the Cantabrian Alps of northern Spain. Eren the reindeer invaded this region (Harlé) but the stag $(C$. elaphus) is more abundant. The moose (Alces) also invaded the Pyrenees and northern Spain. The Saiga antelope (S. tartarica) occurs at thirteen localities in southern France (Harlé), and the steppe suslik (S. rufescens) is very abundant.

It is a grand assemblage of the European Forest and Meadow types mingled with a few Eurasiatic-Alpine types, abundant Eurasiatic Forest types, but with the Tundra and Steppe types predominating numerically until the close of the Magdalenian period, when the Forest types again begin to greatly predominate. The numerical succession in Germany and Austria may be tabulated from the invaluable tables presented by 
Schmidt. Tre owe our knowledge of the cold fauna of southern France chiefly to Harlé (18:1-1912).

Tostglacial. Datun Stage, Azilian-Tal lelloisian C'ul-

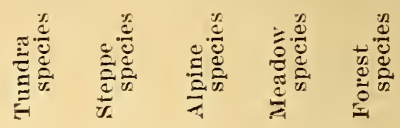
tule, Ofnet. Istein . . . . . . . . . . . . . . . .

I'ostglacial, Gschnitz Stage. Hohlefels, Late Magdalenian Culture...................

I'ostglacial, Middle Magdalenian C'ulture. Vlyel Rodent strata................... 10

Fostglacial, Early Magdalenian C'ulture, Biihl Stage, Sirgenstein................ ! Postglacia], High Magdalenian Culture, Thaingen. 15 I'ostglacial. High Maglalenian Culture. Schwreizersbild ....................

I'ostglacial, Solutrean C'ulture........... 6

I'ostglacial. Late Auriguacian Culture......... 10

I'ostælacial, Aurignarian C'ulture. Sirgenstein.

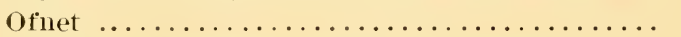

IV. Glacial Maximum, Lower Rodent Layer.... T

IV. Glacial Stage, Mousterian Culture.........

The fauna of Vöklinshofen includes a similar intermingling of tundra, steppe, mountain, and meadow-forest types. The same is true of the scattered deposits ${ }^{s i}$ in Thuringia near Saalfeld, Gera, Jena, Leipzig, etc. The loess fauna near IIüzburg, Bararia." also includes twenty species of mammals divided into typically modern tundra forms of northern Asia, typical modern steppe forms of central Asia and Siberia, together with the four characteristic great mammals of the period, the mammoth, the woolly rhinoceros, wrus and bison. The arctic character of the famna of châteauneuf-sur-('harente ${ }^{\text {:s }}$ in central France is rery conspicuous, most of the species belonging either to the tundras or the steppes of modern Europe. The bones of many young animals occur in this deposit, which may be explainer perhaps on the supposition that the animals fell into the fissure while the opening was lightly covered with snow, the young being the most frequently entrapper. Among the chief localities where this grand Fourth Glacial and Postglacial fauna have been discovered are the following:

\footnotetext{
87 Poнlig, II. : "Torläufige Mittheilungen über das I'listocæn, insbesondere Thüringens," Sitzungsber. Niederrhein. Ges. Bonn, pp. 2-15. Mar. 2, 1884.

88 NehrixG, A.: "Ủbersicht über vierundzwanzig mitteleuropäische Quartäl-Faunen," Zeitschr. deutsch. geol. Ges., pp. 468-509. Jahrg. 1880.

\&oule, M., and Chauret, G.: "Sur l'existence d'une faune d'animaux arctiques dans la Charente à l'époque quaternaire," C. R. Acad. Sci. Paris, Vol. XXVIII, pp. 11s81190.1899.
} 


\section{Localitics}

Kesslerloch Cave. neal Thaingen (Fig. 9, 37)

ScHWElzersbiro Cave. near Schatthausen (:37)

Scattered deposits in Thuringia. in northern Geruany,

Saalfeld. Gera. Jena. Leipzig (29.30.31)

Würzburg, Bararia, Loess deposits (33)

Swabla and Fraxcoxia. cave deposits

Vöklisshofex. Alsace (2S)

Moxtiarrix Cave (Haute-Garonne), Upper levels (35) Magdalenian Stage ChÃteal’xeuf-sur-Charente (Charente) (36)
Gulture Zones

Magdalenian Stage

Magdalenian Stage

Aurignacian and Solu-

trean stages

Folutrean Stage

Aurignacian and Solu-

trean Stages

The large mammals of the period are more fully known than in any prerious Pleistocene stage both through palæontological researches, which date back to the beginnings of the science of vertebrate palæontology in Germany and France, and through the extraordinarily accurate carvings and drawings in the carerns of Dordogne and northern Spain. These drawings hare been reproduced with remarkable fidelity, chiefly by Breuil. ${ }^{90}$ The chief elements in the larger mammal fauna were as follows:

Forest axi MEADOW FAUNA

Moose. Alces patmatus

Persian deer, Cervus maral

Red deer, crapreolus capreolus

Roedeer. Cervus slaphus

Wild cattle. Brs primigenius

Bison. Bison misrus

Forest horse, Equus caballus

Bear. Trsus spelorus

Lion, Felis leo spelca

Brown bear. Trsus aretos

Wild boar. Sus scrofa

TUNDRA FACNA

Woolly rhinoceros, Dieeros antiquitatis

Wroolly elephant. Elephas primigenius

Musk ox, oibibos moschatus

Iieindeer. Rangifer tarandus

Aretic fox. Vulpes lagopus

Elasmothere. Elasmotherium sibiri$(\cdot 11)$
Schueizersbitd Cave (Fig. 9. 3\%).- The Magdalenian, or reindeer man apparently arrived in the Schaffhausen region long after the maximum Fourth glaciation, during the Biihl adrance, the period of deposition of the "Upper Rodent" layer with its cold Arctic and Steppe fauna. The deposits of the Schweizersbild cave as recorded by Nehring ${ }^{91}$ present the fullest succession and extend over a very long period of time as exhibited in the following layers:

Neolithic:

ז. Gray culture layer forest fauna.

so See publications of Abbé Ilenri Breuil. Marcellin Boulr, Le Comte Begouen. I'. Bourrinet. I. Capitan. Emile Cartailhac. Ialanne. Lartet and ('hristy, Déchelette, Hugo Obermaier, resrony, Reinach. Others are in preparation.

$r$ NenRisg, A. "ţbersicht ïber vierundzwanzig mitteleuropaische quartär-Fannen." Zeitschr. Deutsch. Geol. Ges.. pp. 468-509. 1880.

: "Ibje kleineren Wirbeltiere vom Schweizersbild bei schaffhausen," Denkschr. allg. schweiz. Ges. gesäm. Naturwiss., Vol. xxxv, pp. 41-77. 1896. 


\section{STLPPE FAUNA}

Saiga antelope, dutelope saimu

Asiatic wild ass, Equus hemionus

Wild horse, E. praewalskii? sp.

Jerboa, Alactaga jaculus

Desert horse, E. caballus celticus

ALPine Fauna

Ibex, Ibex priscus

Chamois, Rupicapra
Lialisulithic, Magdalenian:

4. Upper Ereccia, or "Upper Ro. dent" layer, steppe fauna.

3. Yellow culture layer, palieolithic "Reindeer Age," steppe fauna.

2. Lower Breccia, or "Lower Rodent" layer, animal remains and traces of man, tundra fauna.

1. Diluvial layer. No fossils.

(2) Of these the "Lower Rodent" layer contains a pure arctic tundrat fauna, such as the vole, hare, fox, the reindeer, the ptarmigan. There are no traces of man. In the layer above these the early steppe animals begin to appear, the hamsters and picas. (3) Then in the "Yellow ('ulture" layer there is an assemblage of pure steppe forms, susliks, dwarf picas and wild horses, all pointing to the absence of forests; but at the top of this layer the first squirrel (Sciurus) appears as the harbinger of forests. (4) In the "Upper Rodent" layer the steppe fauna begins to be intermingled with an increasing number of forest types, such as squirrels, dormice, and the pine marten. (5) Finally we reach the "Gray Culture" layer, composed of the modern forest dwellers, such as the squirrel, the beaver, the pine marten, the stag. the roe, the wild boar, the brown bear. The "Lower Rodent" layer is contemporaneous with the Mousterian culture, while the "Upper Rodent" layer belongs to Magdalenian times. The uppermost "Gray Culture" layer with its forest fauna belongs either to the closing Palæeolithic or to Neolithic times.

Kesslerloch Cave.-Similar conclusions result from the study of the geologic conditions surrounding the Kesslerloch Cave of Thaingen in Switzerland (Fig. 9, 3\%). This famous care lies on the edge of a moderately wide valley, traversed by a brook. ${ }^{92}$ In this sheltered, wellwatered, hilly region, woods flourished and harbored the forest animals, at the same time that the glaciers retreating southward left damp and stony areas, closely followed by a tundra fauna. The woolly rhinoceros and the mammoth persisted longer here than in other parts of Europe. As analyzed by Nïiesch, we discover here mammals distinctive of the tundras, of the steppes, of the modern Alps (marmot, chamois, ibex), of the meadow-forests (bison, urus), and finally of the modern forest type (lion, wolf, brown bear, pine marten, squirrel, wild boar, and stag). These mammal zones undoubtedly correspond with the passing or evolution of

${ }^{22}$ NUESCH, J.: "Das Kesslerloch, eine Höhle aus paläolithischer Zeit. Neue Grabungen und Funde." Neue Denkschr. allg. schweiz. Ges. gesam. Naturwiss., Vol. XXXIX, Pt. 2, pp. 1-72. 1904 
several human culture stages (perhaps the Aurignacian, Solutrian, and Magdalenian). While the tundra fauna was pushing southward into the heart of Switzerland, it had already vanished from central Germany, Belgium and France, where it had been superseded by a steppe, or even a meadow-forest fauna. The human artifacts show that these deposits are contemporaneous with those of Schweizersbild, both belonging to Magdalenian times. A hearth, with ashes and coals, and many charred bones of old and young mammals, including the woolly rhinoceros, have been found here. The human remains show that a race of pigmies dwelt here smaller even than the small men of Schweizersbild, their height being estimated at $120 \mathrm{~cm}$. (4 feet)..$^{93}$ The horse of Kesslerloch shows many resemblances to the Przewalsky horse of the high steppes of Central Asia. ${ }^{94}$

It is characteristic of these faunas that among species still living are mingled remains of the great extinct mammals of the times. Another feature is that occasionally the Steppe, Tundra and Forest faunas are found either nearly pure or entirely distinct and separate as in the lower deposits of Thiede near Braunschweig, above cited. More often as in Schweizersbild and Kesslerloch they are successive or superposed upon each other.

Besicle the cavern deposits are those in the loess. Thus in the "Upper Loess" near Würzburg, Bavaria, Nehring 95 has recorded both a Tundra and a Steppe fauna, including beside the still living types the woolly rhinoceros, the mammoth, the urus and the bison.

\section{MIGRATIONS OF THE LARGE MAMMALS OF THE FOURTH GLACIAL AND} POSTGLACIAL PERIOD

Over the greater part of the Iberian Peninsula the stag (Cervus elaphus) took the place of the reindeer. There is no trace of the entrance of the Steppe Fauna at any period into Spain or Portugal. The Pyrenees also presented a barrier to the greater part of the tundra fauna, yet the Norwegian lemming (Myodes Temmus) penetrated Portugal to the vicinity of Lisbon. The cold fauna (E. primigenius, $E$. antiquitatis, $U$. spelcus, $F$. spelca) is not represented in Portugal, but $E$. primigenius has been discovered in two localities on the extreme northern coast of Spain, in the Province of Santander bordering the Bay of Biscay. $D$. antiquitatis also occurs in the same province.

SËESCH : op. rit., p. 21.

24 STCDER, T.: "Die Knochenreste aus der Höhle zum Kesslerloch bei Thayngen," Neue Denkschr. allg. schweiz. Ges. gesam. Naturwiss., Vol. XXXIX, Pt. 2, pp. 73-112. 1904.

95 NEHRING, A.: "Übersicht über vierundzwanzig mitteleuropäische Quartär-Faunen," Zeitschr. Deutsch. Geol. Ges., pp. 468-509. 1880. 
Rangifer larandus is found in the carem of Seringa south of the Pyrenees (Torralba). It also has been recorded recently (Obermaier) in the carern of Altamira, near Santander. The Alpine chamois (Rupicapra) occurs south of the Pyrenees and the ibex is traced to Gibraltar.

Thus Harlé96 concludes it is certain that the "cold fauna" of France spread along the northern coast of Spain flanking the Pyrenees into Catalonia, including the mammoth, reindeer, chamois, woolly rhinoceros, and spreading as far west as Santander. This is also the range of the Crô-Maguon race of men.

Mammoth.-The woolly mammoth (E. primigenius) now reaches the height of its evolution and specialization. As preserved in the frozen tundras of northern Siberia and as represented in very numerous drawings and engravings by the Upper Palæolithic artists, it is the most rompletely known of all fossil mammalia. Its proportions as shown in the accompanring figure, which represents the information gathered from all sources, are entirely different from those of either the Indian or African elephant. The head is very high and surmounted br a great mass of hair and wool. Behind this is a sharp depression separating the back of the head from the great dorsal hump. The hinder portion of the back falls away very rapidly and the tail is short. 'The orercoat of long hair nearly reaches the ground, and beneath this is a warm undercoating of wool.

As described by Salensky ${ }^{97}$ from the wonderfully complete specimen discovered in 1901 on the banks of the Beresowka River in northeastern Siberia, this animal developed characters which absolntely exclude the possibility of its ancestry or relationship to the existing Indian elephants. The hind foot was four-toed, or tetradactyl, and not five-toed as in the living forms. The head was larger as compared with the length of the body than in recent elephants, a character which stands in close connection with the enormous derelopment of the tusks: these were distinguished by their spiral form, the points directed inward. The ears were very small and covered with hair. The tail was relatively shorter than in the existing elephants and was provided with a tassel of long. bristly hair at the end. The color of the hair was yellowish brown, rarying from light brown to pure brown, and a coat of woolly hair, 2 to $21 / 2 \mathrm{~cm}$. in length, covered the whole bodv. Interspersed with these were a large number of longer and thicker hairs which formed mane-like patches on

\footnotetext{
${ }_{96}^{6}$ Harle. Enovard: "Les Mammifères et oiseaux quaternaires connus jusqu"ici en Portugal. Memoire suivi d’une liste générale de ceux de la Téninsule lbérique." Communic. du Service Géol. du Portugal, Tom. vili, pp. 22-85. pll. I-V. Lisbon. 1910.

${ }^{97}$ Salexsir. W. : ẗber die Hauptresultate der Erforschung des im Jahre 1901 am Tfer der Reresowka entdeckten männlichen IIammutcadavers," C. R. Séa. Six. Congr. Internat. Zö̈I., pp. 67-\$6. Berne, 1904.
} 
the cheeks, on the chin, on the shoulders, flanks, abdomen, etc. A broad fringe of this long hair extended along the sides of the body as depicted in the palacolithic sketches from the Combarelles Cave discovered by Capitan and Breuil in 1901. Especially interesting is the food found in the stomach and mouth, which consists of a meadow flora such as characterizes this region of siberia at the present day, thus appearing to disprove the theory that the climate was milder than that now prevailing. Tor does it appear that it was more frigid, because there are few repre-

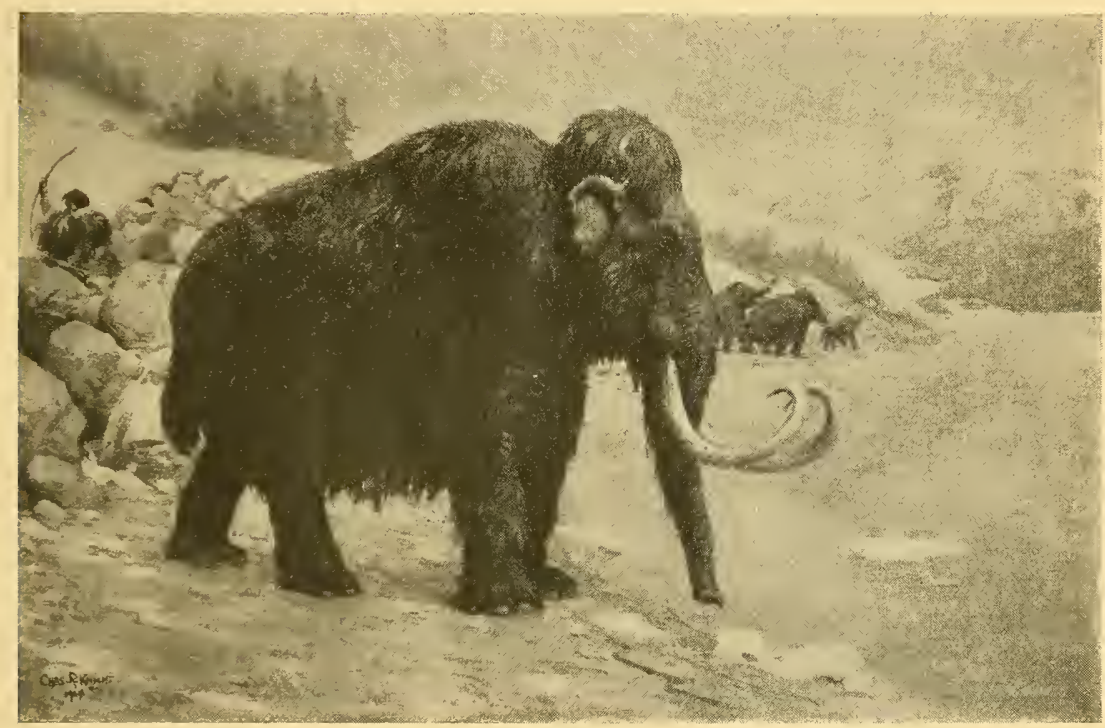

Fis. 18.-The hairy mammoth (Elephas primigenius) and Paloolithic man (Homo acanderthatensis)

Restored by Charles R. Knight under the direction of the author, 1914. Original in the American Iusenm of Natural History, New York City.

sentatives of tundra regetation. (trasses (Graminea) and sedges ( $C y$ peracere) predominate. There were also wild thyme (Thymus), beans of the wild oxytropis (Oxytropis rompestris), seeds of the alpine poppy (Papacer), and the boreal variety of the upright crowfoot (Ranunculus (arer), all still found in this region.

Woolly Phinoreros.-The woolly rhinoceros (D. antiquitatis, D. tichorlinus) is distinctly a cold-weather, or tundra form and the invariable companion of the mammoth. Tike $D$. merchii it has no front, or cutting teeth hence it has been improperly considered as related to this sperios but it really belongs to the modern African gromp of Diceros (Ate- 
lodus), which is distinguished by a very elongate front horn (Fig. 19) and a small posterior horn, as in the existing white rhinoceros ( $D$. simus) of Africa. The resemblance of the cave drawings of the Pleistocene animal to the living form is very close indeed except as regards the heary coat of hair, which, as in the mammoth, extends far below the body. The hair of the face, of a golden brown color with an undercovering of wool, is preserved in the St. Petersburg Museum. Through a discovery (1911) at Starunia ${ }^{98}$ in East Galicia this animal is now

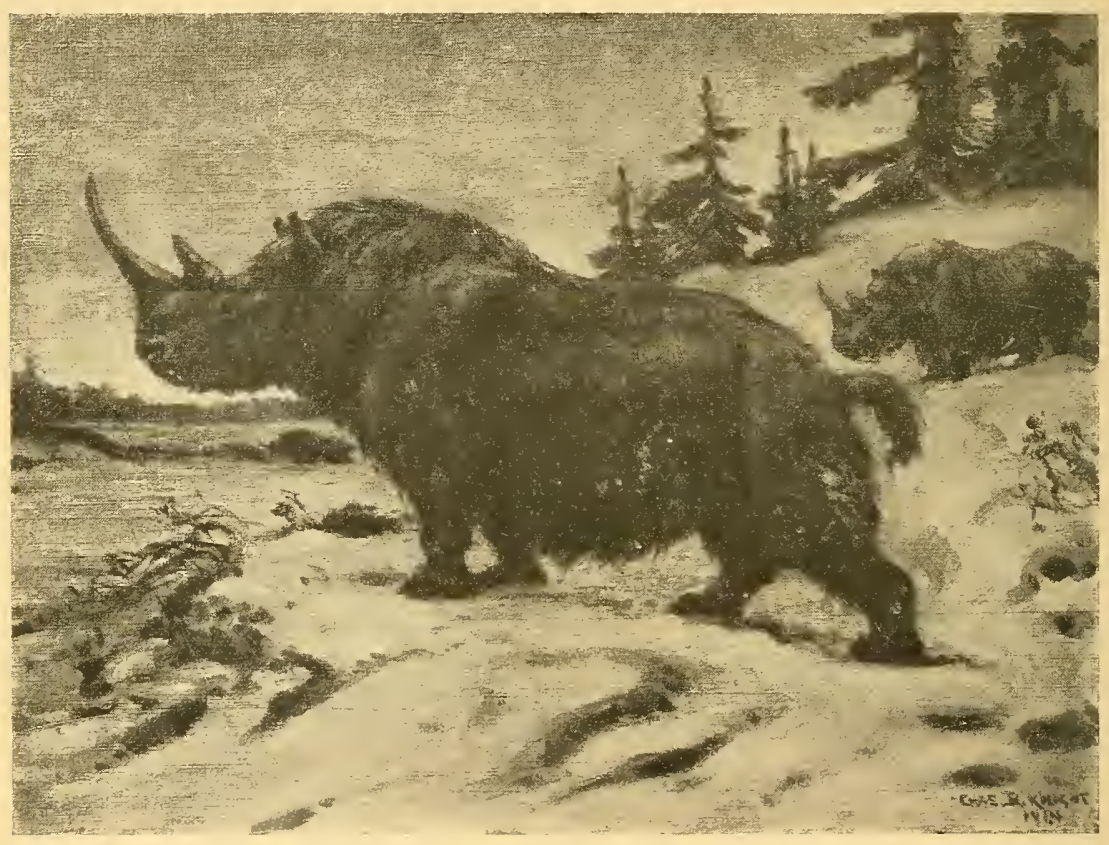

FIG. 19.--The woolly rhinoceros (Diceros antiquitatis)

Restored by Charles $\mathbf{R}$. Knight under the direction of the author, 1914. Original in the American Museum of Natural Histors, New York City.

completely known to us except the tail. The remains of the woolly rhinoceros were found at a depth of $13.6 \mathrm{~m}$., including the head, the left fore leg and the skin of the left side of the body, all with the musculature but lacking the hair. The Starunia specimen exhibits a broad, truncated upper lip, small, oblique eyes, ears long. narrow and pointed, a long nasal horn with oval base and shorter frontal horn, a short neck,

98 Niezabitowski, E. L.: "Die ťberreste des in Starunia in einer Erdwachsgrube mit Haut und Weichteilen gefundenen Rhinoceros antiquitatis Blum. (tichorhinus Fisch.). Vorlaufige Mitteilung." Bull. Acad. Sci. Cracorie. Ser. B. pp. 240-26T. April, 1911. 
on the back of which is a small hump quite independent of the skeleton. The larger hump on the shoulders is formed by the long vertebral spines. The legs are comparatively short. The skin is smooth. Niezabitowski observes that $D$. antiquitatis resembles $D$. simus most closely, having in common the elongate head with prominent orbits, the truncated upper lip, the hump on the neck, and the short legs: it differs from $D$. simus in the somewhat narrower muzzle. small, pointed ears and the presence of a thick coating of hair.

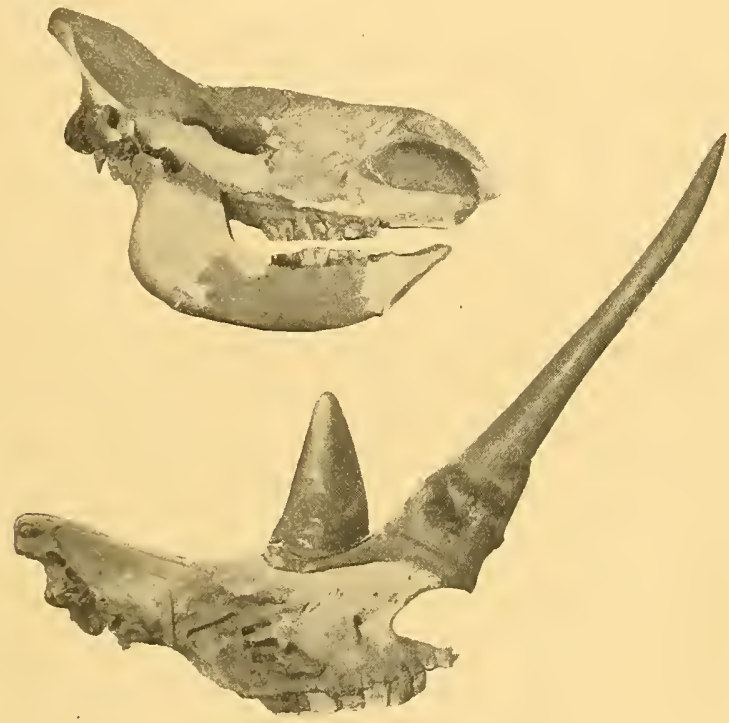

litg. 20.--Rhinor eros sliulls

Skulls of the l'leistocene "woolly rhinoceros," Diceros antiquitatis of Eurasia (abore), and of the recent African "white rhinoceros," Diceros simus (below). In the American Museum of Natural History.

Like $D$. simus, D. antiquilatis was a plains dweller living on grass and small herbs. The woolly rhinoceros was confined more closely to the edges of the great ice sheets than the mammoth; that is, it did not migrate so far to the south, stopping at the Alps, while the mammoth wandered into Italy as far south as Rome.

Elasmotheres. - The elasmothere (Elasmotherium sibericum) was another companion of the mammoth which ranged over eastern Europe, Germany, and southern Siberia. It was probably a steppe dweller. In Pleistocene times it is reported as occurring as far south as Sicily. ${ }^{99}$ It

\footnotetext{
59 Braxdt, J. F.: "Mitheilungen über die Gattung Elasmotherium, besonders den Schädelbau derselhen." Mem. Acar. Imper. Sci. lótersbourg. Ser. V11, Vol. XXVI, No. 6.

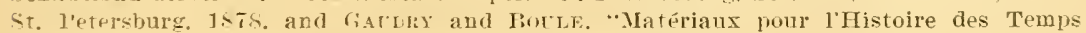
Quaternaires." Fasc. 31. LiElasmotherinm. Paris. 1888.
} 
is a gigantic animal, distinguished fom all the Eurnean Pleistocene rhinoceroses by the entire absence of the anterior horn and the possession of an enormous horm situated on the forehear between the eres; a]so by the elaborate foldings of its dental enamel, to whieh the name Elasmotherium refers. Its hypsodont and follerl teeth were especially adapted to a grassy diet, and Gaudry connects its appearance in Europe with the extensice deforestation accompanying the Steppe and T'undra periods of mammalian life. It apparently wandered into Europe from central Asia and never became very abundant. 'The elasmothere is possibly descended ${ }^{100}$ from the Aceratherium of the T pper Miocene of Eppelsheim which has perfectly smooth, pointerl nasals, and the rudiment of a horn betreen the eyes.

Horses of the Pleistocene.-The horse was distributed all orer the northern hemisphere in Pleistocene times in the Glacial, Interglacial, and Postglacial Epochs. In America no Postglacial horses are found. In Europe horses were apparently abundant in Postolacial times and two of the natural breeds appear to have given origin to two of the modern domesticated types. The horses of the long warm Second Interglacial Stage were remarkable for their great size ( $E$. süssenbornensis, E. mosbachen $x$ is) which exceeded that of the largest recent breeds (Pohlig, 190\%). ${ }^{101}$ According to Pohlig the horses were at all times aecompanied by the wild asses ( $E$. hemionus) but this we are inclined to believe was a special feature of the dry and cold steppe periods in which we should expect to find asses sinilar to the dzeggetai of Asia of present time. The existing wild ass, or kiang, of the Asiatic steppes certainly appears in early Postglacial times at Wildscheuer, Thaingen, Kesslerloch, and Schreizersbild associated with the late Aurignacian Palæolithic culture. Reference of the ancient Pleistocene horses to E. caballus is certainly erroneous. The comnection of these ancient Pleistocene horses with the molem species and races requires further investigation.

We should expect to discover in Europe horses of three different habitats or life zones. namely, of the dry African-Asiatic plains. of the Eurasiatic forests and meadows, of the tundras and steppes. Such anticipation appears to be rerified through the new lines of study instituted by Ewart 102 since 1904. Following more or less closely the work of prerious students of the Equida he has shown that the different wild breeds of horses have evolved in three kinds of enviromment. Thus we riscover

100 Osbors, H. F. : "Frontal Horn on Aceratherium incisicum. Relation of the type to Elasmotherium," Science. N. S., Vol. IX. No. 214. pp. 161-162. Feb., 1899.

101 Pohlig, H. : Eiszeit und Trgeschichte des Menschen. Leipzig, 1907.

102 EWArT, J. Cossar : "The Multiple Origin of IIorses and Ponies." Trans. Highland. Agric. Soc. of Scotland, pp. 1-39. $1 ! 10 !$. 
horses adapted to: (1) forests and upland valleys; (D) high, dry, cold steppes: (3) warm deserts and plateaus. In these three chief habitats the horses may be respectively known as the "forest horse," the "steppe horse," and the "desert horse." Each has its distinctive coloring, tooth structure. and proportions of the skull, body and limbs, in adaptation to its peculiar mode of life.

The forest horse is relatively a large, clumsy animal. The face is arched, as in the modern draught horse. The limbs are short, the front cannon bone (IItc. III) being short and stout, the length only $51 / 2$ times the width. The tail is depressed in contrast with that of the desert horse. According to Errart this type of horse (E. robustus) occurs at Solutré and in the Neolithic deposits of Ilford (Essex), and Kent. In Aurignacean times Solutré was the site of a great open air Palæolithic camp. Toussaint enumerates fragments of at least 100,000 horses, which mingled with other bones of the chase formed a sort of rampart around the camp. The majority of these horses belonged to the stoutheaded. short-limbed forest, or Norse type, measuring 54 inches (13.2 hands) at the withers, the size of the existing pony. ${ }^{103}$ The large joints and honfs were especially adapted to the low-lying marshy ground in the ricinity of forests. and the long teeth and powerful jaws were adapted to feerling during parts of the rear on coarse grasses, roots and other hard substances. There is no evidence that the men of the Aurignacean age either bred or reared these animals. The majority of the remains are those of horses from five to seven years of age. This type of horse is engrarer on the walls of the cave of Combarelle, where the drawings are chiefly of old Magdalenian age and the pure forest type of horse is most frequently represented. There is also a small, fine-headed type suggesting the desert horse. and a larger, long-armed type suggesting the wild ass.

The desert horse is the Pleistocene animal identified by Richard Oren as an ass (E. asinus fossilis), but considered to be a horse by Ewart and named by him E. graritis. This is a small animal, not over 12.2 hands in height, slender-limber, with long, slender front cannon bones (Mte. III), the length being $: 1 \%$ times the width. The head is small, the face fine and narrow, with a straight profile only slightly deflected upon the cranium. The internal cusp (protocone) of the upper molars is short. Remains of an animal of this type are found in the Pliocene of Italy (small. slender-limbed rarieties of E. stenonis) and France, and in the Pleistrorene of France and northern Africa. It agrees, so far as known, with the existing Celtic pony type (E. caballus celticus). a variety of 
horse distinguished by small, fine head, large eyes, slender limbs, five lumbar rertebræ, now found in more or less pure form in the outlying islands and on the coast of western Europe. This animal is believed to be a northern, hardy, thick-coated relative of the pure desert type, better known as the Arabian. which gare rise to the modern thom Perfect representations of this type of horse are found in the engravings and mural paintings of the Magdalenian artists in the caverns of Font de Gaume, Combarelle, and Grotte de la Mairie.

A possible contributory to the desert breed of the Pleistocene and of the modern domesticated horses is the animal of the $E$. sivalensis type of the Tpper Pliocene in the Siwaliks of India. This animal is tall, with long, fairly slender limbs, long neck, well elevated tail, long face, which is strongly deflected on the cranium with a slightly convex profile and broad brow, and teeth with a narrow protocone.

Bears.-The Postglacial bears (Ursus spelckus) are found in greater abundance than the lions. They include a gigantic and a smaller variety. The former (Crsus spelaus) nearly equalled the larger recent bears in size and were more thick-set and of heavier proportions: the front paws especially were of tremendous size. During a long period the care bears undoubtedly haunted the caverns undisturbed by Palæolithic man and developed certain peculiarities of structure in these haunts: thus the claw-bearing phalanges are feebly developed, indicating that the claws had partly lost their prehensile function; the anterior premolar teeth are practically vestigial: the cusps of the grinding teeth are blunted in a way which is indicative of an omnivorous diet. It would appear, therefore, that the large herbivorous mammals and even primitive man found no rery formidable enemy in the care bear. While the other and smaller races were contemporary. there are certain indications that the smaller race (Ursus sub-spelcus) was geologically older, being found at Mosbach during the Second Interglacial Stage. Both races became extinct during Postglacial times without leaving descendants.

The ancestor (Ursus arctos priscus) of the brown bear of Europe, by some believed to be a descendant of the etruscan bear (Ursus etruscus) of the First or Norfolkian Interglacial Stage, is also occasionally found in the Pleistocene care deposits. It is not so large as the care bear and while it has been mistakenly identified with the American grizzly ( $U$. homibitis) in reality it has closer affinities to the European brown bear (Ursus arctos).

The badger (Meles taxus) also probably originated in west-central Asia. since the only other species known are confined to Asia. The two 
extinct Lower Pliocene species are found in Maragha, Persia (M. polaki, M. Maraghanus). ${ }^{104}$

\section{TRANSITION TO THE EUROPEAN FOREST STAGE}

This transition is believed to have begun late in Postglacial times, toward the end of the Magdalenian culture period. Evidence that the mammoth fauna lingered late both in the Dordogne region of central France and to the north is found in the abundant representation of the mammoths in the very latest paintings and engravings by the Magdalenian artists.

\section{MIGRATION OF THE TUNDRA FAUNA}

The backward or northward migration of the Tundra fauna is beliered to hare occurred in the following manner. ${ }^{105}$ As the glacial caps retreated they left barren stretches behind them and the valleys and plateaus now free from ice became tundras where swamps alternated with patches of polar willows and stunted fir trees, while other areas were covered merely with low, scrubby birches or reindeer moss and lichens. As these climatic conditions shifted northward before the retreat of the great Scandinavian glaciers the Tundra fauna followed. It was a slow change that drove the Tundra mammals toward the dry regions of the east to make room for the forests and their faunas advancing from the south. It is clear that the north and east were the only directions of retreat for the damp climate and the spread of the woodlands.

\section{RETREAT OF THE STEPPE FAUNA}

As long ago as 1890 Nehring $^{106}$ held that the Steppe period of central Europe was partly in Postglacial times. This opinion was supported by Woldrich (1896), ${ }^{107}$ and has been abundantly confirmed by Harlés observations in southern France and by the recent researches of Koken and Schmidt. Steppe conditions of climate appear probable from the extensive depositions of the "Newer Loess" in Postglacial times (Koken,

${ }^{104}$ SChARFF, R. F.: The History of the European Fauna, p. 44. London, 1899.

100 Studer, T.: "Die Tierreste aus den pleistocænen Ablagerungen des Schweizer'sbildes bei Schafthausen." Neue Denkschr. allg. schweiz. Ges. Gesam. Naturwiss., Vol.

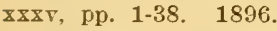

100 Nehrivg, A.: Über Tundren und Steppen der Jetzt- und Vorzeit, mit besonderer Berücksichtigung ihrer Fauna, pp. 81-166. Berlin, 1890.

${ }_{107}$ ToldRICH, J. N.: "Ueber die Gliederung der anthropologischen Formationsgruppe Mitteleuropas." Sitzber. kgl. böhm. Ges., math. naturwiss. Class., 1896. Ref. Matiegka in Centralblatt Anthrop., pp. 142-143. 1896. 
Schmidt). On the other hand, Kobelt ${ }^{10 s}$ and Scharff ${ }^{109}$ agree in thinking that the presence of Steppe mammals affords inadequate proof of the steppe character of the country in Inter- and Postglacial times. The deposits of the "Newer Loess" in Postglacial times point to a dry steppe period because according to the theory of Richthofen, which is now generally accepted, the loess owes its origin to wind-borne dust and sand acting under the influence of a dry climate either in summer or winter.

The Steppe Fauna in deposits at several points is shown to have lingered longer than the Tundra fauna. As regards the lingering of the Steppe Fauna it is indicated in the succession of the three rodents characteristic of the Tundra, Steppe and Forest conditions respectively, namely:

Forest climate and conditions, the squirrel (Sciurus vulgaris)

Steppe climate and conditions, the jerboa (Alactaga jaculus)

Tundra climate and conditions, the banded lemming (Myodes torquatus)

The absence of fossil plants in the deposits of the steppe period is due to the unfavorable conditions for the preservation of plant remains. Small stretches of woodland were probably confined to the banks of rivers, to favorable mountain slopes, etc. The flora was probably like that of eastern Eurasia or southwestern Siberia to-day. In their migrations such animals as the jerboa which were unable to swim presumably crossed the rivers while frozen over.

Saiga.-Of the Steppe fauna (fully described on p. 248) the saiga antelope (Saiga tartarica) has at the present time retreated to the steppes of eastern Europe and westcrn Siberia. This animal is represented in the carvings and engravings of Upper Palæolithic or latc Magdalenian times in the Dordogne rcgion of France. Its fossil remains have been found in thirteen localities in southwestern. France in association with a cold steppe fauna. In the same region have been found remains of the musk ox $(O v i b o s)$.

SURVIVAL OF FOREST AND MEADOW FAUNA

The final retreat of the cold faunas of the tundras and steppes occurred during the late stages of the Upper Palæolithic Magdalenian culture. The most advanced Magdalenian art continues to represent the woolly mammoth in the cavern of Font de Gaume (Dordogne) and elsewhere, but in the very latest Magdalenian culture stages it would appear that the mammoth and woolly rhinoceros were becoming rare. This final

108 Kовецт, W. : Die Verbreitung der Tierwelt. Gemässigte Zone. Leipzig, 1902.

${ }^{109}$ Scharfs, R. F. : The History of the European Fauna. London, 1899. 
Magdalenian culture, which is correlated with the Gschnitz advance (Schmidt, op. cit., p. 2\%0), is later than the Steppe period of the "Upper Rodent" layer, which is correlated with the preceding Bühl advance.

At the same time the Crô-Magnon, or Aurignacian type of Homo sapiens, which we believe to be the artistic race of the Reindeer period, disappears or becomes greatly reduced in numbers and new brachycephalic and dolichocephalic races of men enter Europe.

Azilian-Tardenoisian, Final Upper Palaolithic Culture.-This is regarded as the closing culture of Upper Palæolithic times. It is believed to be associated with the newly arriving broad-headed FurfoozGrenelle race. Although this point is not positively determined this race is first found at Ofnet in Bavaria. It is readily distinguished from the preceding Magdalenian culture by the degeneration of the stone industry into microlithic and other types and by the entire disappearance of art in all its forms. The Azilian culture is essentially Palæolithic although it embodies only its last degenerate stages. While the perfection of the older crafts was lost forever the Neolithic arts of polishing stone, making pottery, cultivating land and domesticating animals are as yet utterly unknown. The Azilian is the age of the stag for there is no longer any trace of the reindeer or other Tundra forms. The bone implements are now made of the horns of the stag. The Tardenoisian culture, supposed by some to be distinct from the Azilian, is characterized by flint microliths of unusual fineness, but it appears that the Azilian and Tardenoisian cultures are contemporary (Obermaier, 1912).

There were two or more human races in Europe in these pre-Neolithic times including brachycephalic and dolichocephalic types which are found commingled at Furfooz. In the meantime Palæolithic races were advancing in the north along the shores of the Baltic and preceding the Campignian culture, which is the first of the Neolithic arrivals in the Baltic region.

Forest Fauna.-The spread and multiplication of the Eurasiatic Forest Fauna thus occurred before the close of Palæolithic times. Following the retreat of the glaciers and the disappearance of steppe conditions of climate there came a gradual subsidence of the coasts of northern Europe and with it a more humid climate favorable to reforestation. Besides the common squirrel (Sciurus vulgaris) which is the herald of forest conditions all over the northern hemisphere, there appear in larger numbers the entire Forest Fauna which we have traced from its beginnings in early Pleistocene times and which we regard as having been resident in farorable localities throughout the entire epoch. With the Tundra and Steppe Faunas disappear also the wolverine (Gulo luscus) and the lion 
(Felis leo spelca), which are never found in western Europe after the Pleistocene although the lion lingered until a late period in eastern Europe.

The Alpine Fauna, which is mainly of central Asiatic rather than of northern relationships, retreats to the higher levels of the Alps and the Pyrenees. Thus there remained in the forests, in the plains and in the lower mountain regions of Europe the direct descendants of the Eurasiatic Forest and Meadow Fauna of the Pleistocene. It is noteworthy that no new mammals appear in Europe at this time except those introduced by man. The fauna of early Neolithic times is directly sequent upon that of late Palæolithic times. This fauna has been discovered in the Swiss lake dwellings ${ }^{110}$ (Fig. 9, 38-40) at Moosseedorf, Wauwyl, Robenhausen, Concise, etc. In the peat bogs of Hassleben (41), etc., in the travertines of Jena, Iangensalza (42), etc., ${ }^{111}$ have been found the following mammals:

\section{Forest and MEAdow}

Bison bonasus, the European bison, still surviving in Lithuania.

Bos primigenius, collateral ancestor of the long-horned larger existing cattle of western Europe. The "urus," of Cæsar's text. Surviving in Germany until the sixteenth century.

Bos longifrons, the "Celtic short-horn," the probable ancestor of the small breeds of British short-horned and hornless cattle.

Cervus elaphus, the red deer or stag.

Cervus capreolus, the roe deer.

Alces machlis, the elk ol moose.

Rangifer tarandus, the reindeer, surviving in central Europe until the twelfth century.

Cervus dama, the fallow deer.

Sus scrofa ferus, the wild boar.

Sus scrofa palustris, the turf pig.

Equus caballus celticus, the Celtic pony, representative of the "plateau" type.

Equus caballus typicus, the Norse, or "forest" horse.

Castor fiber, the beaver.

Sciurus vulgaris, the common squirrel.

Lepus timidus, the European hare.

Lepus variabilis, the arctic hare, in Ireland and the north.

Mus sylvaticus, the field mouse.

Arctomys marmotta, the marmot of the alpine fauna.

Ursus arctos, the brown bear.

Meles taxus, the badger.

\footnotetext{
110 RÜtimerer, L. : "Die Fauna der l'fahlbauten der Schweiz," Neue Denkschr. allg. schwelz. Gesell. gesam. Naturwiss., Yol. XIX. Züıich, 1.562.

111 РонLIG, H.: "Vorlänfige Mittheilungen äbel das Plistocæen, insbesondere Thüringens," Sitzungsber. Niederrhein. Ges. Bonn, pp. 2-15. Mar. 3, 1884.
} 
Mustela martes, the pine marten, also the weasel, pole cat, the ermine, etc.

Lutra vulgaris, the otter.

Gulo luscus, the wolverine.

Canis lupus, the wolf.

Canis vulpes, the fox.

ALPINE

Felis catus, the wild cat.

Capra ibex, the ibex of the mountain or alpine fauna.

Rupicapra tragus, the chamois of the mountain fauna.

There is evidence of the "plateau" or "Celtic" horse in the Neolithic deposits of Essex and of Switzerland (La Têne); it was widely distributed in Europe and Asia in prehistoric times. ${ }^{112}$

It is beyond the purpose of this volume to trace the history of domestication. The dog (Canis familiaris), a descendant of the wolf (Canis lupus), first appears in western Europe late in Upper Palæolithic times. ${ }^{113}$ The Neolithic immigrants, or men of the New Stone Age, possessed or brought with them cattle, sheep, goats, pigs, horses and dogs. Appreciating the value of domestication, they certainly captured and domesticated three indigenous European species, namely, the Celtic shorthorn cattle, the forest horse (E. caballus typicus) and the Celtic horse (E. caballus celticus). The wild ox (Bos primigenius) was hunted but not domesticated. The domestic ox (Bos taurus) shows many points of resemblance to the Urus, but is not directly descended from it, but rather from the Bos trochoceros type of the Pleistocene of Italy. Ruitimeyer has made an exhaustive study of this subject, ${ }^{114}$ tracing the origin of the various types of domesticated cattle.

112 EWART, J. C. : Op. cit., 1907.

113 E. Trodessart consider's the diminutive wolf of India, Canis pallipes, as the princlpal if not the sole source of all our races of domestic dog. This species of wolf, with the rxception of the Sumatran wolf. Canis sumatrensis, is also more closely related thun any other to the dingo of Australia. "L'Origine préhistorique du chlen domestique," Revue des ldées, pp. 38s-411. June 15, 1911.

I1 RŨTimeyer, L. : "Die Fauna der Pfahlbauten der Schweiz," Neue Denkschr. allg. schweiz. Gesell, gesam. Naturwiss., Vol. XIX. Züirich, 1\$82. 





\title{
PUBLICATIONS
}

OF THE

\section{NEW YORK ACADEMY OF SCIENCES}

\author{
(Ltyceum of Natural History, 1817-18\%6)
}

The publications of the Academy consist of two series, viz.:

(1) The Annals (octayo series), established in 1823, contain the scientific contributions and reports of researches, together with the records of meetings and similar matter.

A volume of the Annals coincides in general with the calendar year and is seld at the uniform price of three dollars per volume. The articles composing the volume are printed separately, each in its own cover, and are distributed in bundles on an average of three per year. The price of the separate articles depends upon their length and the number of illustrations, and may be learned upon application to the Librarian of the Academy. The author receives his separates as soon as his paper has been printed, the date of issue appearing above the title of each paper.

(2) The Memoirs (quarto series), established in 1895, are issued at irregular intervals. It is intended that each volume shall be devoted to monographs relating to some particular department of Science. Volume I is devoted to Astronomical Memoirs, Volume II to Zoölogical Memoirs, etc. The price is one dollar per part as issued.

All publications are sent free to Fellows and Active Members. The Annals are sent to Honorary and Corresponding Members desiring them.

Subscriptions and inquiries concerning current and back numbers of any of the publications of the Academy should be addressed to

The Librarian,

New York Academy of Sciences, care of

American Museum of Natural History, New York, N. Y. 
